LESSONS LEARNED AT WEST VALLEY DURING FACILITY DECONTAMINATION FOR RE-USE

Topical Report

By

D. Tundo

R. F. Gessner

R. E. Lawrence

November 1988

Work Performed Under Contract No. AC07-81NE44139

West Valley Nuclear Services Co., Inc.

West Valley, New York 


\section{DISCLAIMER}

This report was prepared as an account of work sponsored by an agency of the United States Government. Neither the United States Government nor any agency thereof, nor any of their employees, makes any warranty, express or implied, or assumes any legal liability or responsibility for the accuracy, completeness, or usefulness of any information, apparatus, product, or process disclosed, or represents that its use would not infringe privately owned rights. Reference herein to any specific commercial product, process, or service by trade name, trademark, manufacturer, or otherwise does not necessarily constitute or imply its endorsement, recommendation, or favoring by the United States Government or any agency thereof. The views and opinions of authors ex. pressed herein do not necessarily state or reflect those of the United States Government or any agency thereof.

This report has been reproduced directly from the best available copy.

Available to DOE and DOE contractors from the Office of Scientific and Technical Information, P.O. Box 62, Oak Ridge, TN 37831; prices available from (615)576-8401, FTS 626-8401.

Available to the public from the National Technical Information Service, U.S. Department of Commerce, 5285 Port Royal Rd., Springfield, VA 22161.

Price: Printed Copy A05 Microfiche A01 


\section{DISCLAIMER}

This report was prepared as an account of work sponsored by an agency of the United States Government. Neither the United States Government nor any agency Thereof, nor any of their employees, makes any warranty, express or implied, or assumes any legal liability or responsibility for the accuracy, completeness, or usefulness of any information, apparatus, product, or process disclosed, or represents that its use would not infringe privately owned rights. Reference herein to any specific commercial product, process, or service by trade name, trademark, manufacturer, or otherwise does not necessarily constitute or imply its endorsement, recommendation, or favoring by the United States Government or any agency thereof. The views and opinions of authors expressed herein do not necessarily state or reflect those of the United States Government or any agency thereof. 


\section{DISCLAIMER}

Portions of this document may be illegible in electronic image products. Images are produced from the best available original document. 


\title{
LESSONS LEARNED AT WEST VALLEY DURING FACILITY DECONTAMINATION FOR RE-USE (1982-1988)
}

TOPICAL REPORT
By
D. Tundo
R. F. Gessner
R. E. Lawrence

November 1988

Work Performed Under Contract No. DE-AC07-81NE44139

\author{
Prepared for \\ U.S. Department of Energy \\ Theodore Garrish \\ Assistant Secretary for Nuclear Energy \\ Prepared by \\ West Valley Nuclear Services Co., Inc. \\ P.O. Box 191 \\ West Valley, New York 14171-0191
}




\section{LESSONS LEARNED AT WEST VALLEY DURING FACILITY DECONTAMINATION FOR RE-USE (1982-1988)}

\section{TABLE OF CONTENTS}

PAGE

Executive Summary . . . . . . . . . . . . . . . . . . . . . . . . . vi

Lessons Learned Summary . . . . . . . . . . . . . . . . . . . . . . . viii

1.0 INTRODUCTION . . . . . . . . . . . . . . . . . . . . . . . . . . . . . . . . . 1

2.0 DESCRIPTION OF SITE AT PROJECT START $\quad . \quad . \quad . \quad . \quad . \quad . \quad . \quad . \quad . \quad . \quad . \quad . \quad . \quad . \quad . \quad 3$

3.0 FACILITIES NEEDED TO SUPPORT PROJECT MISSION . . . . . . . . . . . . . . . . 5

4.0 MANAGEMENT STRATEGY

5.0 ENGINEERING AND SAFETY DOCUMENTATION $\quad$. . . . . . . . . . . . . . . . . . . . . 9

6.0 ASSEMBLY AND QUALIFICATION OF PERSONNEL . . . . . . . . . . . . . . . . . 10

6.1 Assembly . . . . . . . . . . . . . . . . . . . . . . . . . 10

6.2 Qualification . . . . . . . . . . . . . . . . . . 10

7.0 SPECIFIC DECONTAMINATION TASKS . . . . . . . . . . . . . . . . . . 12

7.1 Laboratory Facilities . . . . . . . . . . . . . . . . . . . . . 12

7.2 Operating and Maintenance Aisles and Areas 2 . . . . . . . . . . . . . . 18

7.2.1 Extraction Chemical Room (XCR) . . . . . . . . . . . . . . . . . 20

7.2.2 Upper and Lower Warm Aisles (UWA, LWA) . . . . . . . . . . . . . . . 20

7.2.3 Extraction Sample Aisle (XSA) . . . . . . . . . . . . . . . . . . . . 21

7.2.4 Master Slave Manipulator Repair Shop (MSMRS) ～. . . . . . . . . . . 21

7.2.5 Chemical Viewing Aisle (CVA) . . . . . . . . . . . . . . . . . . . . . . . 21

7.2.6 Decontamination Shop . . . . . . . . . . . . . . . . . . . 21

7.2.7 01-14 Building . . . . . . . . . . . . . . . . . . . . . 23

7.3 Major Cells in Extraction Aisle $\quad$. . . . . . . . . . . . . . . . . . . . . . . . . 23

7.3.1 Extraction Cell $3(\mathrm{XC}-3) \quad$. . . . . . . . . . . . . . . . . . . . . . . . 23

7.3.2 Product Purification Cell (PPC) $\quad$. . . . . . . . . . . . . . . . . . . . . 24

7.3.3 Product Handling Area (PHA) . . . . . . . . . . . . . . . . . . . . 24

7.4 Cells to be used for Vitrification _. . . . . . . . . . . . . . . . . . . . 30

7.4.1 Chemical Process Cell (CPC) . . . . . . . . . . . . . . . . . . . . 30

7.4.2 Equipment Decontamination Room (EDR) . . . . . . . . . . . . . 32

7.4.3 Chemical Crane Room (CCR) . . . . . . . . . . . . . . . . . 32

7.5 High-Level Waste (HLW) Tank Farm . . . . . . . . . . . . . . . . . 35

7.5.1 Supernatant Treatment System (STS) . . . . . . . . . . . . . . . . . 35

7.5.2 Sludge Mobilization System (SMS) $\quad$. . . . . . . . . . . . . . . . . . . . . . 35

8.0 SPECIAL TOOLING AND TECHNIQUES . . . . . . . . . . . . . . . . . . . . 41

8.1 Routine Methods . . . . . . . . . . . . . . . . . . . . . . . . . . . . 41

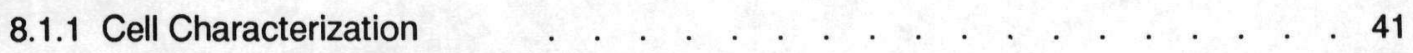

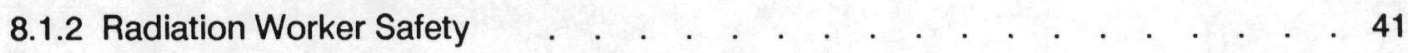


8.1.3 In-cell Safety Procedures . . . . . . . . . . . . . . . . . . . . 44

8.1 .4 Contamination Control $\quad . \quad$. . . . . . . . . . . . . . . . . . . . . . 47

8.1.5 In-Cell Surface Decontamination Methods $\quad$. . . . . . . . . . . . . . . 47

8.1.6 Waste Packaging . . . . . . . . . . . . . . . . . . . . . 47

8.2 Robotics and Remote Applications . . . . . . . . . . . . . . . . . . . . . . 47

8.3 High-Pressure Water Abrasives $\quad . \quad$. . . . . . . . . . . . . . . . . . . . . . . . . 51

8.4 Size Reduction . . . . . . . . . . . . . . . . . . . . . . . . . . . . . . 59

9.0 COST BENEFIT ANALYSIS $\quad$. . . . . . . . . . . . . . . . . . . . . . . . . . . . . . . . . 66

10.0 RADIOLOGICAL EXPOSURE SUMMARY . . . . . . . . . . . . . . . . . . . . . 68

11.0 ACKNOWLEDGMENTS . . . . . . . . . . . . . . . . . . . . . . . 70

12.0 REFERENCES $\quad . \quad$. . . . . . . . . . . . . . . . . . . . . . . . . . . . . . . . . 71

13.0 BIBLIOGRAPHY . . . . . . . . . . . . . . . . . . . . . . . . . . . . 73 


\section{FIGURES}

1. Decontamination Status--December 1988 . . . . . . . . . . . . . . . . . 13

2. Decontamination Activities for Facility Re-use $\quad$. . . . . . . . . . . . . . . . . . . . . . . 14

3. Deteriorated Analytical Cell Zinc Bromide Shielding Window $\quad$. . . . . . . . . . . . . $\quad$. 17

4. Refurbished Analytical Cell Viewed from Analytical Aisle $\quad$. . . . . . . . . . . . . . . . . . . $\quad$. 19

5. MSMRS During Decontamination . . . . . . . . . . . . . . . . . . . . 22

6. MSMRS After Decontamination . . . . . . . . . . . . . . . . . . . . . . . . . . . 22

7. Scale Model of $\mathrm{XC}-3 \quad$. $\quad . \quad$. . . . . . . . . . . . . . . . . . . . . . . . . . . . . . . . . 25

8. Vessel Being Removed from XC-3 During Cleanup $\quad$. . . . . . . . . . . . . . . . . . 26

9. LWTS Vessel Installation in XC-3 after Cleanup _ . . . . . . . . . . . . . . . . . . . . 27

10. "Spider" Work Platform . . . . . . . . . . . . . . . . . . . . . . . . . . . . . 28

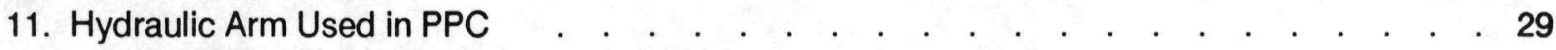

12. HLW Interim Storage and Vitrification Facility $\quad$. . . . . . . . . . . . . . . . . . . . . 31

13. CPC Before and After Decontamination . . . . . . . . . . . . . . . . . . . . . 33

14. Using Tipping Fixture and Crane to Tip Pedestal onto Transfer Car in CPC . . . . . . . 34

15. High-Level Waste Tank $\quad$. . . . . . . . . . . . . . . . . . . . . . . . . . . . . . 36

16. Remote Controls for Riser Installation $\quad . \quad$. . . . . . . . . . . . . . . . . . . . . . . . . . 38

17. Riser Being Installed . . . . . . . . . . . . . . . . . . . . . . . . . . . . . . . . 39

18. Final Riser Welding c. . . . . . . . . . . . . . . . . . . . . . . . . . . . . . . 440

19. Suiting Up for Cell Entry $\quad$. . . . . . . . . . . . . . . . . . . . . . . . . . . . . . 45

20. Device for Removing Liquid Samples (Telltale) from Pipes $\quad$. . . . . . . . . . . . . . . 46

21. Fixing Contamination in Pipes Prior to Cutting, the Interior Is Filled with Polyurethane Foam 48

22. Surface Cleaning Tool Used for Cell Decontamination c . . . . . . . . . . . . . . . . . . 49

23. Storage Facility Used o Contain and Shield Vessels Removed from the CPC ～. . . . 50

24. Preprogramming a Robot for CPC Sampling and Cleanup of Debris $\quad$. . . . . . . . . $\quad$. 52

25. Abrasive Jet Nozzle Assembly . . . . . . . . . . . . . . . . . . . . . . . . . . . . . . . 53

26. Cutting Arrangement for Opening Passageway from the Vitrification Facility
to HLW Storage Area (EDR)

27. Removal of EDR Outer Layer of Blocks after High-Pressure Water/Abrasive Cutting . . 56

28. Setup for Pedestal Cutting . . . . . . . . . . . . . . . . . . . . . . . . . 57

29. Underwater Sectioning of Canisters Used to Store Spent Fuel . . . . . . . . . . . 58

30. Abrasive Saw Designed by WVNS for Remote Volume Reduction . . . . . . . . . . . 61

31. Commercially Available Abrasive Saw Adapted for Use by CPC . . . . . . . . . . . . . . 62

32. Plasma Arc Cutting in Contact Size Reduction of Contaminated Vessels . . . . . . . . . . . 63

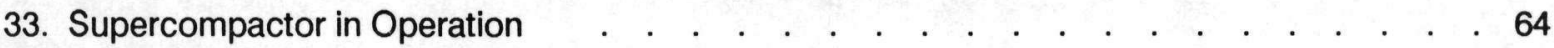

34. Example of Supercompactor Volume Reduction $\quad$. . . . . . . . . . . . . . . . . . . . . 65

35. Analysis for Decontamination and Reuse vs New Construction . . . . . . . . . . . . 67 


\section{TABLES}

1. Cell Characterization Program

2. Cell Decontamination Summary $\quad$. . . . . . . . . . . . . . . . . . . . . . . . . . . . $\quad$. 16

3. Summary of Areas, Costs and Exposures for Decontaminationof Plant Locations for HighLevel Waste Storage c. . . . . . . . . . . . . . . . . . . . . . . . . . . . . 35

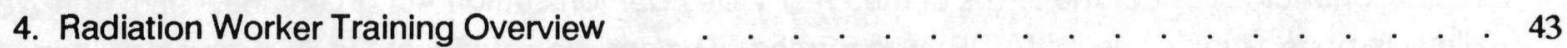

5. Total Personnel Exposure for Various D\&D Operations $\quad$. . . . . . . . . . . . . . . . . . . 69 


\section{EXECUTIVE SUMMARY}

In February 1982, the Department of Energy (DOE) began a cleanup project In West Valley, New York, at the only commercial fuel reprocessing plant licensed in the United States. West Valley Nuclear Services, Co., Inc. (WVNS), a wholly owned subsidiary of Westinghouse Electric Corp., was engaged as the site contractor. Under the terms of the West Valley Demonstration Act (PL96-368, 1980), the West Valley Demonstration Project (WVDP) was formed. The act stipulated that the DOE and New York State Energy Research and Development Authority (NYSERDA) share in the cost of the Project.

The primary mission of the WVDP is to solidify a large volume of high-level liquid waste (2.3 million liters - 600,000 gallons) produced during reprocessing plant operations and stored in underground tanks. This is to be accomplished through the maximum use of existing facilities. This required a significant effort to remove existing equipment and to decontaminate areas for installation of liquid and cement processing systems in a safe environment while maintaining exposure to workers as low as reasonably achievable.

The reprocessing plant occupied a building of about $33,000 \mathrm{~m}^{2}\left(350,000 \mathrm{ft}^{2}\right)$. When the WVDP was initiated, approximately 6 percent of the plant area was in a non-contaminated condition where personnel could function without protective clothing or radiological controls. From 1982 to 1988, an additional 64 percent of the plant was cleaned up and much of this converted to low- and high-level waste processing areas. The high-level liquid and resulting low-level liquids are now being treated in these areas using an Integrated Radwaste Treatment System (IRTS). The Project has now focused attention on installation, qualification and operation of a vitrification system which will convert the remaining high-level waste into borosilicate glass logs. The stabilized waste will be sent to a Federal Repository for long-term storage.

From 1982 to 1988, about 70 technical reports were published dealing with specific tasks and cleanup efforts. This report provides an overview of the decontamination and decommissioning work done in that period. The report emphasizes lessons learned during that effort. Significant advances were made in:

- Remote and contact decontamination technology

- Personnel protection and training

- Planning and procedures

- Radiological controls

Overall, the decontamination efforts at West Valley have demonstrated that nuclear cleanup and waste management can be done efficiently, safely and at lower cost than would accrue from new construction. The West Valley work was done with maximum attention to the safety of workers, the public and 
protection of the environment. The skills employed, technology used and lessons learned will assist others in planning and performing similar projects.

The technology base for decontamination has greatly expanded as a result of the work done at the WVDP. For the first time, decontamination tools and procedures have been developed and used for clean up of a commercial nuclear fuel reprocessing facility to permit installation of waste processing equipment. The systems installed are in use and performing work needed for final decommissioning. 


\section{LESSONS LEARNED SUMMARY}

A brief synopsis of lessons learned during the 6-year period covered by this report is as follows:

\section{- Implementation of Radiological Controls}

Planning and execution of decontamination work was performed with safety waste minimization and productivity priorities. To perform this work safely, each task required:

-characterizing areas and equipment with respect to radiological hazards.

-detailed planning, including radiological controls, to preclude spread of contamination and minimizing radiation exposure.

-preparation of contingency and emergency responses.

-thorough training, supervision and radiological monitoring.

-proper selection and use of protective clothing.

\section{- Respiratory Protection Program}

Routine entries were made into areas of low radiation with high surface contamination. These conditions could lead to a rise in airborne contamination. To prevent ingestion of contaminants, strict controls on worker protection and means of recovery of personnel in emergency situations were implemented. These included:

-use of dual respiratory protection systems, including full-face mask and forced breathing air through a bubble hood.

-providing back-up emergency breathing air supply using bottled air.

-emergency recovery personnel, suited and with breathing air stationed at work area entry points.

\section{- Providing for Operator Comfort}

Layers of protective clothing and breathing apparatus led to operator fatigue after a short time. Cooled breathing air fed directly into the clothing was the most effective technique used to correct this problem.

\section{- Special Tooling}

A variety of commercially available tools and equipment was used. Such items included:

-high-pressure water/abrasives - excellent for cutting concrete and metal. Depth of cut could be controlled to reduce radioactive waste.

-power manipulators - for work in areas where manned entry was not possible. 
-robotics - in areas where radiation fields prohibited manned entry.

-plasma-arc torchs - for cutting heavy metal sections. Special ventilation and dust removal techniques were needed.

-remote drilling, cutting and welding.

-standard cutting tools such as drills and saws (abrasive and metal blades) all had important roles to play.

\section{Sampling Devices}

Unique sampling devices were used for:

-characterization of area contamination and radiation levels.

-testing closed system (piping and vessels) for the presence of liquid and for obtaining samples of liquids for characterization.

\section{- Surface Fixatives and Foam}

Prior to cutting contaminated equipment, surface fixatives and polyurethane foam were used to contain loose contamination. Precautions were needed with both these media since fixatives were hard to remove and the foam was combustible in the presence of acids.

\section{- Old vs. New Equipment}

Manipulators and cranes that were in place during fuel reprocessing had to be replaced. Obsolete equipment had a high rate of failure and spare parts were not available. All manipulators had to be replaced and cranes rebuilt for satisfactory performance.

Shield windows in process cells had to be refurbished to provide visibility and improved shielding.

- Construction Re-use

Cost benefit analysis showed that the cost and time requirement of new constructions for waste treatment facilities would be $\$ 7$ million and 36 months, whereas decontamination and reuse cost was $\$ 4.4$ million and 34 months.

\section{- Waste Volume Reduction}

Facilities were constructed for size reducing contaminated vessels and waste drums to decrease the volume of radioactive waste requiring final disposal. Volumetric reduction factors of 6 to 11 were attained routinely. 


\section{- Radiological Exposure}

An aggressive ALARA campaign is employed at West Valley. Personnel exposures are routinely kept at less than 1 Rem per year for operators, but most personnel receive normal exposure of $<500$ mrem which is less than 10 percent of the DOE annual limit. Detailed procedures, thorough training and extensive use of mock-ups, were aspects of the success of this program. This ALARA program was implemented during the decontamination effort. Total exposures for the areas decontaminated ranged from 0.7 to 11.0 person-rem as explained in the report. 


\subsection{INTRODUCTION}

\section{Background}

The Western New York Nuclear Services Center near Springville, New York, owned by the New York State Energy Research and Development Authority (NYSERDA), was the only commercial nuclear fuel reprocessing facility ever to have operated in the United States. Nuclear Fuel Services Company (NFS), a subsidiary of Getty Oil Company, was the facility operator. The plant reprocessed spent nuclear fuel assemblies from various nuclear power plants from 1966 to 1972 . Reprocessing operations generated over two million liters of high-level radioactive liquid waste. When the plant was built in the early 1960 s, the approved method to manage high-level radioactive liquid waste was underground storage in steel tanks.

In 1971, an NFS decision was made to modify and expand the plant in order to increase production and reliability. This decision mandated extensive decontamination of process vessels, piping and various plant areas which began in 1972.

By 1976 increased federal and state regulations, which applied to the planned expansion and the entire facility, made the required capital investment much more costly than had been anticipated and NFS decided not to proceed with the Project.

In July 1976, NFS informed the NYSERDA and the NRC that it was no longer proceeding with the licensing application to expand and modify the plant. The site was then turned back to NYSERDA in 1980 , leaving the liquid waste in temporary storage tanks at the site. The plant was placed on a standby state with NFS retaining the minimum work force required to maintain safety systems.

\section{West Valley Demonstration Project Act}

Because the operating contract and lease between NFS and New York State Energy Research and Development Authority (NYSERDA) was due to expire on January 1, 1981, the United States Congress enacted and President Carter signed into law the West Valley Demonstration Project (WVDP) Act (PL96-368) in late 1980 authorizing the Department of Energy (DOE) to take over and carry out a nuclear waste management project at West Valley. The Project was established to demonstrate that liquid waste from the reprocessing of spent nuclear fuel could be managed safely in the United States. The objectives of the WVDP are to: 1) solidify high-level liquid waste (2.3 million liters); 2) develop containers for the solidified waste; 3 ) transport solidified HLW to a federal repository; 4) dispose of lowlevel and transuranic waste; and 5) decontaminate and decommission facilities used to support solidification.

The DOE assumed control of the West Valley site in February 1982. West Valley Nuclear Services Company, a subsidiary of Westinghouse Electric Corporation, through a process of competitive bidding, 
was chosen as the site operating contractor. During early Project planning, it was determined that the technology base for waste solidification was known through prior DOE activities dealing with nuclear waste treatment programs. Thus it was determined that the best "demonstration" at West Valley would be the expeditious adaptation of existing technology. The Project would make the maximum feasible use of existing on-site facilities, because minimizing new construction and demonstrating the feasibility of reusing former nuclear process facilities would reduce the extent of the plant stabilization effort required at the end of the Project. 


\subsection{DESCRIPTION OF SITE AT PROJECT START}

When WVNS began operating at the WVDP, a plant survey indicated that 6 percent of the $33,000 \mathrm{~m}^{2}$ $\left(350,000 \mathrm{ft}^{2}\right)$ in the process building was not contaminated. NFS carried on routine decontamination efforts during reprocessing operations from 1966 through 1972. An extensive effort was initiated in 1972 to decontaminate vessels, pipes and various areas for the planned expansion, although NFS did not intend to decontaminate the facility totally. The objective was to reduce radiation and contamination levels to a point where reliability and expansion projects could proceed with low radiation exposure to personnel.

Once the 1976 decision was made to cease operations permanently, all decontamination and modification efforts were terminated. A 1981 NFS report ${ }^{[1]}$ detailed the decontamination efforts by NFS and contained information relative to: (1) the decon procedures used for cell, system and aisle areas; (2) results obtained; (3) chemicals used; (4) problems encountered; and (5) status of the areas. The information in the report was compiled from shift supervisor and operator logs, health and safety files, laboratory records, technical service files and, in some instances, recollections of personnel involved. This information was useful to WVNS in planning the decontamination of the facilities for re-use.

In order to provide an accurate characterization of the site, WVNS performed environmental and radiological surveys. The results of a cell characterization program are summarized in table $1^{[2]}$. The program revealed extremely high levels of radiation (up to $2050 \mathrm{R} / \mathrm{hr}$ in the Process Mechanical Cell) and contamination $\left(10^{6} \mathrm{DPM} / 100 \mathrm{~cm}^{2} \alpha / \beta /\right)$ in many cells.

The following is a description of other general conditions found at the site at the start of the project:

- Hotspots outside of the process building in a water treatment lagoon and an asphalt pad.

- The facility had accumulated dust and painted surfaces were peeling. Radioactive contamination was found in most operating aisles and laboratories in which plant surfaces had been painted to contain contamination.

- The optical quality of the cell viewing windows had deteriorated badly.

- Much of the equipment was in need of repair or no longer operational.

- Some plant areas were badly soiled with grime, insects and contained radioactive wastes, trash and debris. 
Table 1: Cell Characterization Program

Cell

Chemical Process Cell (CPC)

CPC Crane Room

Equipment Decon. Room (EDR)

General Purpose Cell (GPC)

GPC Crane Room

Process Mechanical Cell

\section{PMC Crane room}

Scrap Removal room (SRR)

Extraction Cell 1 (XC-1)

Extraction Cell 2 (XC-2)

Extraction Cell 3 (XC-3)

Product Purification Cell (PPC)

Liquid Waste Cell (LWC)

Acid Recovery Cell (ARC)

Off-Gas Cell (OGC)

Uranium Product Cell (UPC)

Fuel Receiving \& Storage (FRS)
Radiation Levels

Dimensions (W,L,H)

(m)

$7 \times 28 \times 13$
$7 \times 9 \times 5$
$10 \times 13 \times 8$
$3 \times 14 \times 6$
$3 \times 4 \times 6$
$16 \times 4 \times 8$
$8 \times 5 \times 5$
$12 \times 4 \times 4$
$5 \times 5 \times 17$
$6 \times 6 \times 17$
$5 \times 6 \times 17$
$5 \times 6 \times 17$
$14 \times 5 \times 6$
$9 \times 9 \times 10$
$4 \times 10 \times 9$
$14 \times 8 \times 4$
$15 \times 46 \times 6$

$7 \times 28 \times 13$

12.000

0.015

56.000

0.020

0.030

0.200

80.000

650.000

0.050

0.075

40.000

0.300

2050.000

3.000

0.001

0.020

4.000

57.000

0.003

0.001

0.001

0.050

0.500

1.000

0.001

0.001

0.044

0.012

0.175

3.000

1.000

3.000

0.003

0.300

\section{Smearable Contamination}

Beta/Gamma Alpha $\left(\right.$ DPM $\left./ 100 \mathrm{~cm}^{2}\right) \quad\left(\mathrm{DPM} / 100 \mathrm{~cm}^{2}\right)$

$$
\begin{gathered}
>10^{6} \\
>10^{5} \\
>10^{4} \\
>10^{6} \\
>10^{5} \\
>10^{6} \\
>10^{5} \\
10^{3}
\end{gathered}
$$

$>10^{6}$

$>10^{3}$

$10^{2}$

$>10^{6}$

$>10^{5}$

$>10^{6}$

$>10^{5}$

$10^{1}$

Not Determined

$>10^{6}$

$>10^{6}$

$>10^{6}$

$>10^{5}$

$>10^{6}$

$>10^{6}$

$>10^{7}$

Not Determined

Not Determined

$>10^{5}$

$>10^{5}$

$>10^{5}$

$>10$ 


\subsection{FACILITIES NEEDED TO SUPPORT PROJECT MISSION}

\section{Introduction}

The Project mission at the WVDP is to solidify and stabilize the high-level waste (HLW) into borosilicate glass. This requires the following:

- Removeof 2.3 million liters (600,000 gallons) of high-level liquid waste (supernatant and sludge) from Tank 8D-2.

- Develop an ion exchange system (Supernatant Treatment System - STS) to remove Cs-137 from supernatant resulting in low-level liquid waste and high-level ion exchange media.

- Evaporate resulting low-level waste in the Liquid Waste Treatment System (LWTS). This system produces very low-level liquid distillate and a concentrated solution of sodium salts.

- Solidify the concentrated salt solution in a Cement Solidification System (CSS).

- Discharge the very low-level liquid distillate after further processing to remove trace Cs-137 and Sr-90.

- Wash the sludge layer beneath the supernatant in Tank 8D-2 and process the wash solution through STS/LWTS/CSS.

- Combine the sludge, zeolite from STS, THOREX waste from Tank 8D-4 and glass formers to produce borosilicate glass in a Vitrification System (VS). The glass would be poured into stainless-steel canisters for ultimate disposal in a federal repository.

A decision was made early on to maximize the use of the existing space in the former nuclear fuel reprocessing plant. It was decided that areas in the facility would be decontaminated to allow for the installation of many of the new systems to avoid creating new buildings that would ultimately need decommissioning. In part, this decision was based on analysis which concluded that construction would be more costly and take longer than the decontamination and reuse of the existing facility.

Due to this decision, extensive Decontamination Operations were required before the existing plant areas could house the new systems and facilities that support the Project mission. The following is a list of the new facilities/systems and the areas that required decontamination in preparation for their installation $^{[3]}$ :

1. High-Level Waste Interm Storage Facility (HLWISF) - this area will provide interim storage of the borosilicate glass logs. It utilizes: (1) the former Chemical Process Cell (CPC), (2) the Equipment Decontamination Room (EDR), (3) the Chemical Crane Room (CCR), (4) the Chemical Viewing Aisle (CVA) and (5) the Chemical Operating Aisle (COA).

2. Liquid Waste Treatment System (LWTS) - this system is required to process low-level liquid wastes from the Supernatant Treatment System (STS). The process: (1) reduces the volume of liquid from the STS by evaporation, (2) provides concentrated salt solutions to be solidified in 
cement by the Cement Solidification System (CSS) and (3) decontaminates the water removed for safe release into the environment. The LWTS utilizes the space of the following former extraction cells, aisles and areas: (1) Extraction Cell 3 (XC-3), (2) Product Purification Cell (PPC), (3) Uranium Product Cell (UPC), (4) Uranium Loadout Area (ULO), (5) Extraction Chemical Room (XCR), (6) Lower Warm Aisle (LWA), (7) Upper Warm Aisle (UWA), (8) Extraction Sample Aisle (XSA), (9) Lower Extraction Aisle (LXA) and (10) Upper Extraction Aisle (UXA).

3. Analytical Laboratories - the former lab facilities were necessary for use as analytical chemistry laboratories to support the Project by performing chemical analysis required to verify: (1) solidification of waste products, (2) decontamination of plant and (3) operation of plant systems. The analytical labs will also be used for research to support product development. The following reprocessing lab facilities that were decontaminated are identified here by their past and present titles: (1) Hot Lab (now the Radiochemistry Lab), (2) Standard and Quality Control Lab (now the Analytical Chemistry Lab), (3) Alpha Lab and Product Lab (now the Vitrification Lab), (4) Mass Spectroscopy Lab (now the Radiation and Safety Lab), (5) Emission Spectroscopy Lab (now the ICP and CTS Labs), (6) Counting Room (now the Radiochemistry Counting Room), (7) Analytical Cells and (8) Sample Storage Cells.

4. Master Slave Manipulator Repair Shop (MSMRS) - this area will continue in its former role which was to decontaminate service and repair master slave-type manipulators (used in STS, Vitrification and future Decontamination Operations) and similar equipment used throughout the plant.

5. Contact Size Reduction Facility (CSRF) - this facility is required to decontaminate vessels with radiation levels below $100 \mathrm{mr} / \mathrm{hr}$ and to size-reduce them to decrease the volume of waste for disposal. The CSRF is located in the former decon room at the north end of the MSMRS.

6. Cement Solidification System (CSS) - this facility will encapsulate, in cement, the low-level waste salt solution from the LWTS. The CSS was installed in the 01-14 building. Since this building was not used by NFS in reprocessing, minimal decontamination was required.

7. Supernatant Treatment System (STS) and the Sludge Mobilization System (SMS) - the ion exchange columns for STS were installed in a spare tank (8D-1). Pump supports (risers) were remotely installed in Tank 8D-1 and 8D-2 for the Sludge Mobilization System (SMS). The SMS will wash the sludge in Tank 8D-2 and pump the high-level waste to the Vitrification System.

8. Other Operating and Maintenance Areas - the operating and maintenance areas were necessary to gain access to the other plant areas and to serve as a staging area for cell Decontamination Operations and the installation of new systems.

Summaries of the Decontamination Operations for the above areas are located in section 7.0, "Specific Decontamination Tasks." 


\subsection{MANAGEMENT STRATEGY}

As noted earlier, the WVDP plan included the decontamination of the facilities for maximum re-use to support high-level waste (HLW) solidification. A WVNS management strategy developed for the decontamination of the site and plant included four phases:

- Site characterization

- Site stabilization

- Cleanup plant for re-use

- Final site decontamination

WVNS started at the Project by conducting three major surveys in order to characterize the site: (1) A flyover was performed with suspended radiation monitoring equipment, (2) a ground-level survey of several hundred acres was conducted and (3) a detailed survey was taken inside the plant. The surveys formed a radiological baseline that established the radiation and contamination levels that existed on site. The surveys also provided the needed information to safely plan further decontamination strategy.

From the survey results it was determined that the site required initial stabilization work before the plant could be cleaned for re-use. This was necessary to insure a safe working environment for personnel. On-site hotspots such as an asphalt waste storage pad and a lagoon had to be eliminated. Inside the plant, offices and operating and maintenance areas were routinely cleaned of relatively low levels of radiation and contamination, painted and refurbished if necessary.

The next phase of the decontamination strategy was to clean up the plant for its subsequent re-use. A Facilities Utilization Plan ${ }^{[3]}$ was prepared determining how best to re-use the plant areas. The utilization plan was based on an evaluation of the systems needed to support vitrification and the best location for the components and equipment required for these systems.

Most of the areas have been decontaminated and the new facility systems have been designed, installed, tested and are currently being operated. The decontamination goal for the cells was to lower their dose rate to less than $10 \mathrm{mr} / \mathrm{hr}$ to permit full-time access for construction, where possible.

During the cleanup, the WVNS decontamination group worked from the relatively clean, less contaminated areas where contact methods could be used, to the more challenging cells with high radiation and contamination levels using remote technology. As a result of this strategy, decontamination personnel: (1) acquired important knowledge, experience and training and (2) developed the tools and technology required for difficult decontamination tasks. 
Since the inception of the Project, the WVNS decontamination philosophy has been "results" oriented to:

- Assemble a team capable of responding to the technical challenges.

- Develop cost-effective methods and procedures.

- Re-use existing facilities to the maximum extent.

- Complete Decontamination Operations by the contract master schedule need dates.

- Apply available technology to the maximum extent.

- Ensure personnel radiation exposures are kept As Low As Reasonably Achievable (ALARA).

- Protect health and ensure safety of both workers and general public.

- Protect the environment. 


\subsection{ENGINEERING AND SAFETY DOCUMENTATION}

Before work could proceed on decontamination projects, four tiers of safety documentation were required:

1. An Environmental Impact Statement was issued in which an evaluation of various alternatives for decontamination and re-use was included ${ }^{[4]}$.

2. Safety analysis reports and operational safety requirements were issued for the facility and major decontamination efforts.

3. Criticality analyses were performed to ensure there was no potential for criticality while performing the work and to implement controls to prevent criticality accidents when handling fissile materials.

4. Preparation of detailed work procedures containing appropriate radiological, safety and criticality controls. This element includes Work Orders, Radiation Work Permits (RWP) and Industrial Work Permits (IWP). 


\subsection{ASSEMBLY AND QUALIFICATION OF PERSONNEL}

\subsection{ASSEMBLY}

Most individuals who were hired for Decontamination Operations came from industrial/technical work experience backgrounds. These individuals had little or no knowledge of radiation and no experience working in nuclear occupations.

WVNS considered the following when looking for capable people:

1. Education - A minimum of a high school education was required. It was preferred that employees have at least a two-year college degree in a technical field and a strong background in math and science. Employees were recruited through two-year colleges, employment agencies and newspapers.

2. Experience - Nuclear experience was not a prerequisite because of the lack of nuclear trained personnel in the area. WVNS experience showed that persons who had the above education and who possessed positive work skills could be trained and readily adapted to this type of work.

3. Physical - Individuals seeking employment at WVNS were required to be physically fit, capable of doing the required heavy work and work rotating shifts.

\subsection{QUALIFICATION}

All individuals working for WVNS were required to attend a radiation worker training program and pass a final exam (as described in section 8.1.2).

The following is a list of topics that a decontamination operator was required to have specific competencies in:

- Radiation worker training

- Respiratory protection training

- New employee orientation

- WVDP radiological incidents/emergency plan/procedures

- Radiological controls

- Industrial safety training

- Fork lift training

- QA program 
- Criticality safety program

- Crane training

- Rigging and handling equipment

- Elevated work safety training

- CPR training

- First aid training

- Various Standard Operating Procedures

- Contamination and containment

- Decontamination techniques

- Personnel protective clothing

- Good housekeeping practices

- Waste handling and management

- Volume reduction

- Procedures and procedural compliance

In order to advance in skill level, a worker had to pass both written and hands-on qualification tests. Skills must be updated on a frequent basis in order to retain skill qualifications. 


\subsection{SPECIFIC DECONTAMINATION TASKS}

Phase I Decontamination tasks are Operations directed toward the cleanup of those areas identified to house new systems and facilities to support the Project mission. Phase II operations will be the final decontamination of the site meeting criteria to be prescribed by the NRC.

To date, 70 percent of the $33,000 \mathrm{~m}^{2}\left(350,000 \mathrm{ft}^{2}\right)$ in the Process Building has been decontaminated as shown in figures 1 and 2 . The radiological and physical conditions, Decontamination Operation characteristics and costs are summarized in table 2.

Each cell determined to be usable for waste treatment and solidification was cleaned and decontaminated. Reprocessing equipment was removed while useful equipment (in-cell cranes and manipulators) were decontaminated and restored or replaced to achieve operational capability. All unused piping and electrical penetrations into each cell were capped and sealed. Support areas (aisles, stairways...) were also decontaminated to be used as access to, or staging areas for, other decontamination efforts. A description of work in each area is contained in the following sections ${ }^{[5]}$.

\subsection{LABORATORY FACILITIES}

The Laboratory Facilities located on the third floor of the Process Plant were decontaminated in order to support the Project mission ${ }^{[5,6]}$. The facilities consist of: (1) five analytical cells, (2) a Sample Storage Cell, (3) the Analytical Chemistry Lab, (4) the Radiochemistry Lab, (5) the Vitrification Lab and (6) the Radiation and Safety (R\&S) Lab.

The lab facilities required extensive decontamination and refurbishment, especially the five analytical cells and zinc bromide-filled shielding windows. Decontamination Operations in the labs included: (1) general decontamination, (2) removal of all furniture and equipment and (3) remodeling to accommodate the new labs. The analytical cells were contaminated with smearable activity to levels beyond survey instrument counting capability and the exposure rate from gamma radiation ranged up to 2,000 $\mathrm{mr} / \mathrm{hr}$. The optical clarity of the shielding windows for these cells had deteriorated severely beyond use (figure 3).

Each analytical cell was identical (approximately 2 by 2 by 2 meters) containing: (1) drains, (2) two manipulator ports, (3) lighting, (4) shielding door access to Analytical Decontamination Aisle (ADA), (5) electricity and water, (6) ventilation, (7) transfer ports, (8) a shielding window, (9) an intercell conveyer and (10) linkage to areas of the plant by a sample transport mechanism.

The decontamination operational activities were as follows:

1. Unnecessary equipment and debris was removed.

2. Necessary equipment was decontaminated and repaired. 

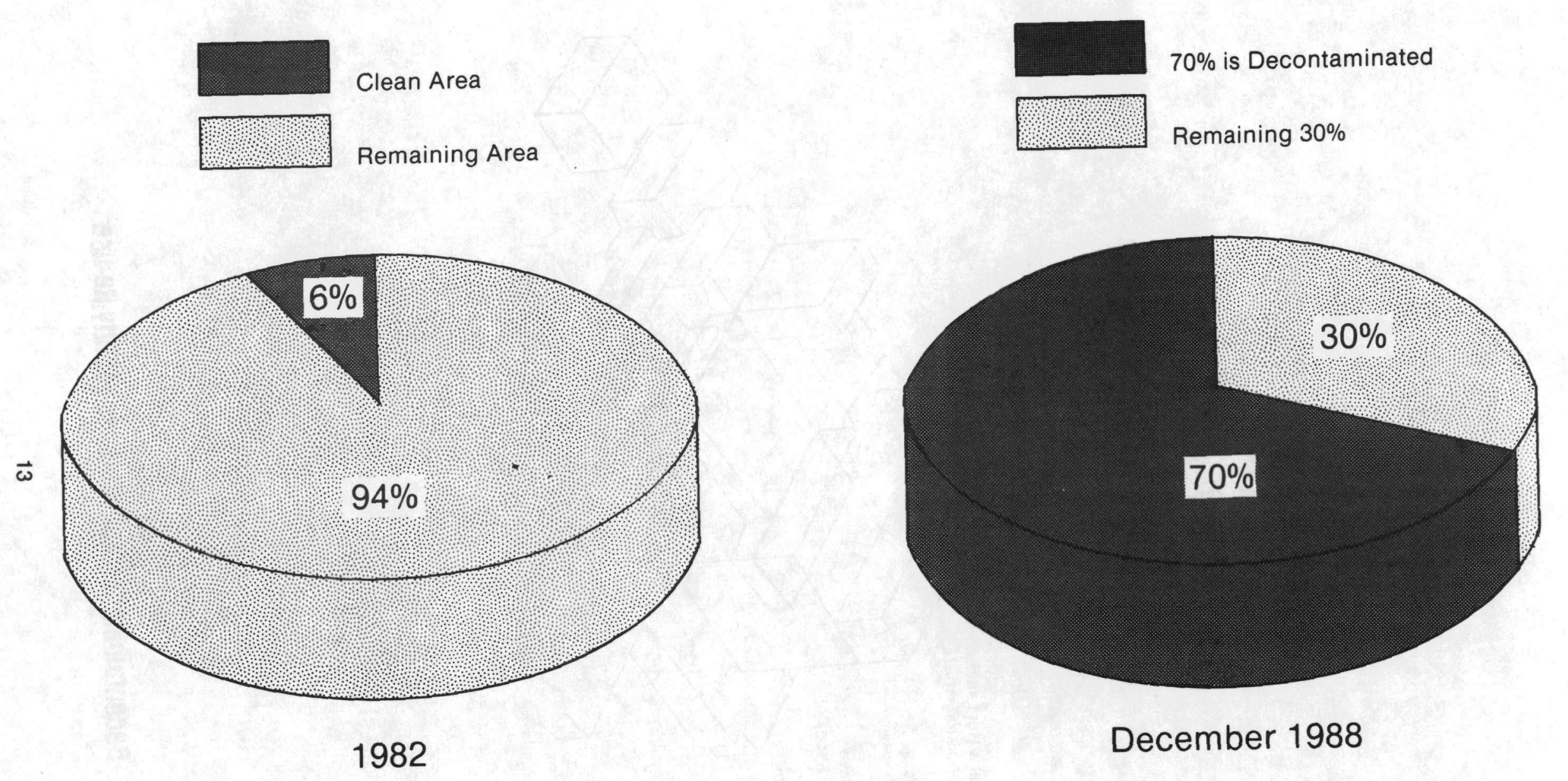

FIGURE 1

Decontamination Status - December 1988 


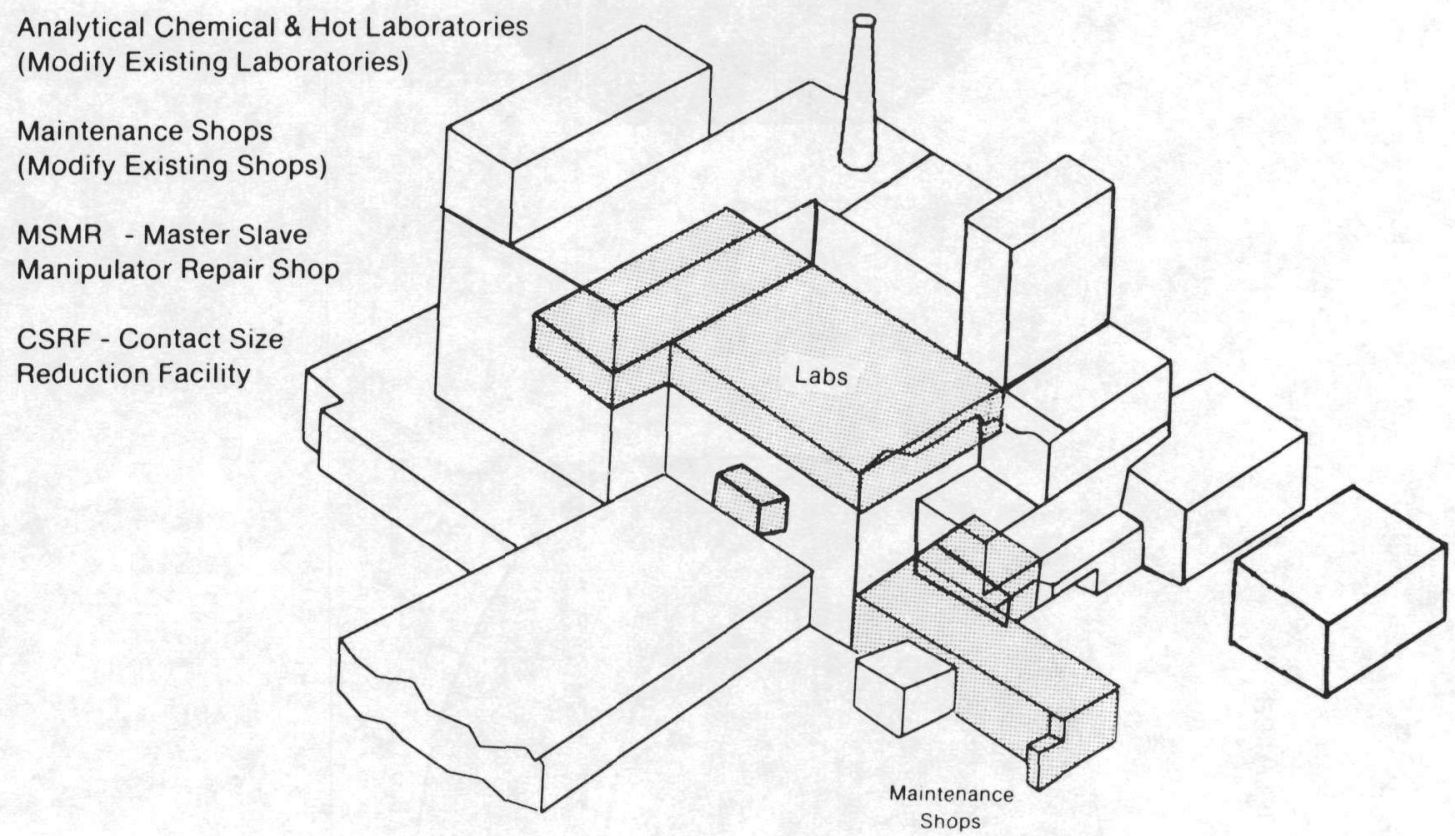

FIGURE 2

Decontamination Activities for Facllity Re-use 
HLW SOLIDIFICATION SYSTEM

- EDR - Equipment Decon Room

- HAC - Hot Acid Cell

- PCR - Process Chemical Room

HLW INTERIM STORAGE

- CPC - Chemical Process Cell

- CCR - Chemical Crane Room

RADWASTE TREATMENT SYSTEM

- XCR - Extraction Chemical Room

- XC-2 - Extraction Cell No. 2

- XC-3 - Extraction Cell No. 3

- PPC - Product Purification Cell

- UPC - Uranium Product Cell

- LWC - Liquid Waste Cell

TRANSURANIC WASTE INTERIM STORAGE (Future)

- PMC - Process Mechanical Cell

- MCR - Mechanical Crane Room

- GPC - General Purpose Cell

- GCR - General Crane Room

- CRE - Crane Room Extension

- MC - Miniature Cell

SIZE REDUCTION FACILITY

- FRS - Fuel Receiving and Storage

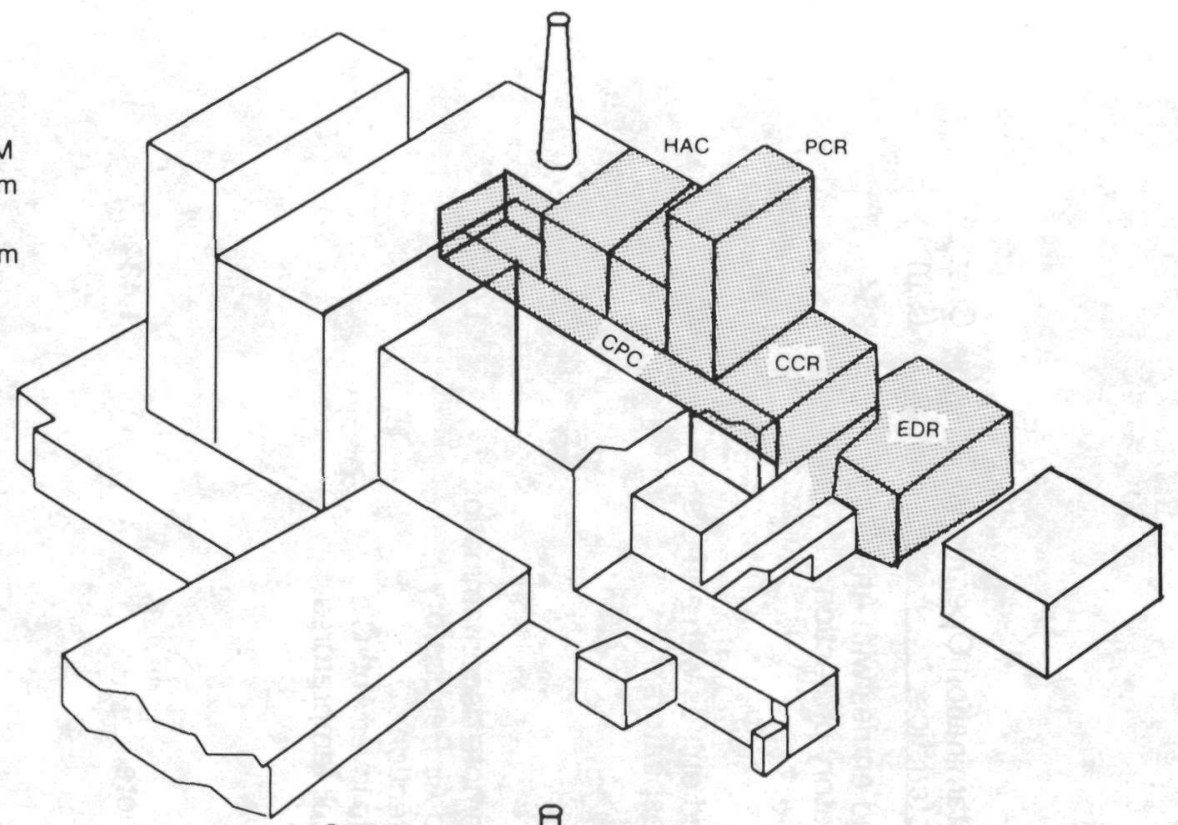

\section{ell}

8 
Table 2. Cell Decontamination Summary

Cell

Cell for Contact

Size Reduction

Facility (MSM

Repair Shop)

Radiochemical and

Analytical Labs

(Alpha Laboratory

and Uranium

Laboratory

Cells and operating

areas identified for

Liquid Waste Treat-

ment System (XCR

XC-3, PPC, UPC,

ULO, UWA, LWA) ${ }^{a}$

Cell for vitrified high-

level waste storage

(Chemical Process

Cell)
Radiological Condition

$0.001-0.020 \mathrm{r} / \mathrm{h}$

$0.005-0.300 \mathrm{r} / \mathrm{h}$

Airborne > Maximum

Permissible Con-

centration (MPC)

\section{$0.001-0.175 \mathrm{r} / \mathrm{h}$}

Airborne > MPC

$12.0 \cdot 56.0 \mathrm{r} / \mathrm{h}$

Airborne > MPC
Physical Condition

Loose hardware

15 glove boxes

Partition wall

Fissile material

present

$5.8 \mathrm{~km}$ pipe

63 metric ton vessels

Limited accessibility

$$
X C-3 \text { and PPC }
$$

No mechanical capability

Required air-cooled vest

in summer months

144 piping jumpers

100 metric tons vessels and dissolvers

45 metric tons pedesta

$$
\text { bases }
$$

2 cranes
Decontamination Operations

Characteristics

Cost

Manned entries with Anti-C's

Respiratory protection

Manned entries with anti-C's and Respirators

Semiremote decontamination Forced Air Respiratory Protection

Multiple layer Anti-C's

High cell tempratures

All remote

\footnotetext{
${ }^{\text {a }}$ Extraction Chemical Room, Extraction Cell 3, Product Purification Cell, Uranium Product Cell, Uranium Load Out, Upper Warm Aisle, and
} 


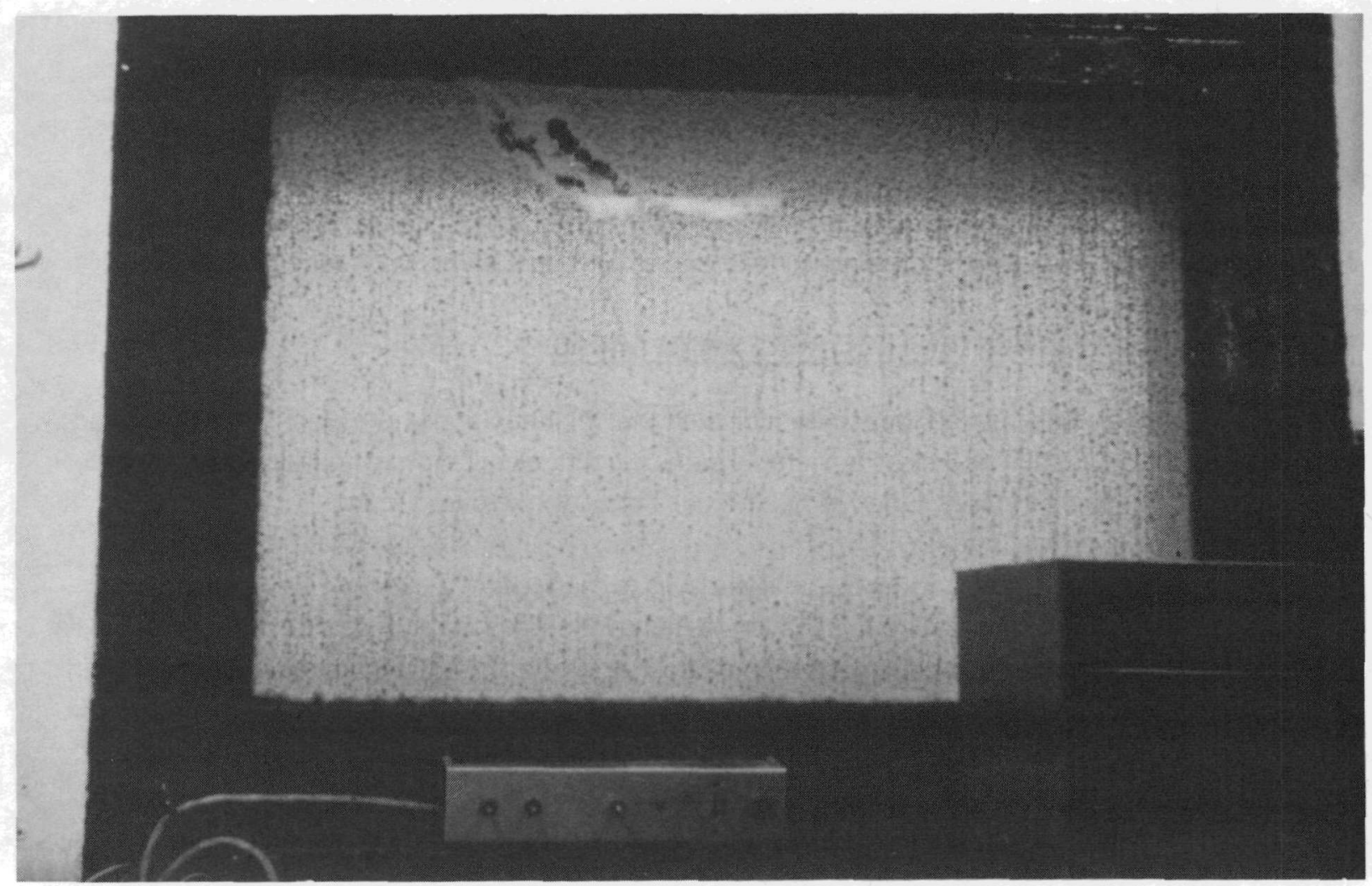

\section{FIGURE 3}

Deterlopated Analytical Gell Zinc Bromide Shielding Window 
3. A Zinc Bromide Refining System was developed and used.

4. Temporary window shielding was installed.

5. The windows were drained and disassembled, the parts cleaned, the frame painted and the windows reassembled.

6. The Zinc Bromide was refined to optical clarity by treatment with hydrogen peroxide, filtration and returned to the windows.

7. Cell interiors were decontaminated.

8. New MSMs were installed.

9. Cell transfer drawers were decontaminated.

10. Cell conveyor system was returned to service.

Figure 4 shows a refurbished analytical cell after the above 10 operations were performed.

\subsection{OPERATING AND MAINTENANCE AISLES AND AREAS}

The initial survey of areas needed for access indicated that the operating and maintenance areas had contamination fixed in paint as well as smearable surface contamination on various floor, sump, wall, door, window, ducting and utility surfaces. Numerous hot spots were also found.

Since these areas were required for almost daily access to many plant areas, they were decontaminated to reduce radiation and contamination to As-Low-As-Reasonably-Achievable (ALARA) levels. They were decontaminated to a height of approximately $2134 \mathrm{~mm}(7 \mathrm{ft})$. Ceiling areas containing intricate networks of plumbing, ductwork and wiring were not decontaminated unless it was necessary to insure the safety of workers in the area or during construction of new facilities.

The following is a list of the operating and maintenance areas that required Decontamination Operations:

1. Extraction Chemical Room (XCR), Upper Warm Aisle (UWA), Lower Warm Aisle (LWA) and Extraction Sample Aisle - Decontaminated for installation of the LWTS in adjacent cells.

2. Chemical Viewing Aisle (CVA) and Chemical Operating Aisles (COA) - Decontaminated to provide plant entry and access to Chemical Process Cell (CPC) for remote Decontamination Operations.

3. Analytical Aisle and Analytical Cell Decontamination Area (ADA) - Decontaminated to provide access for Decontamination Operations and refurbishment of laboratory facilities.

4. Master-Slave Manipulator Repair Shop (MSMRS) - Decontaminated and refurbished to continue to service manipulators and to provide access to the decontamination shop. 


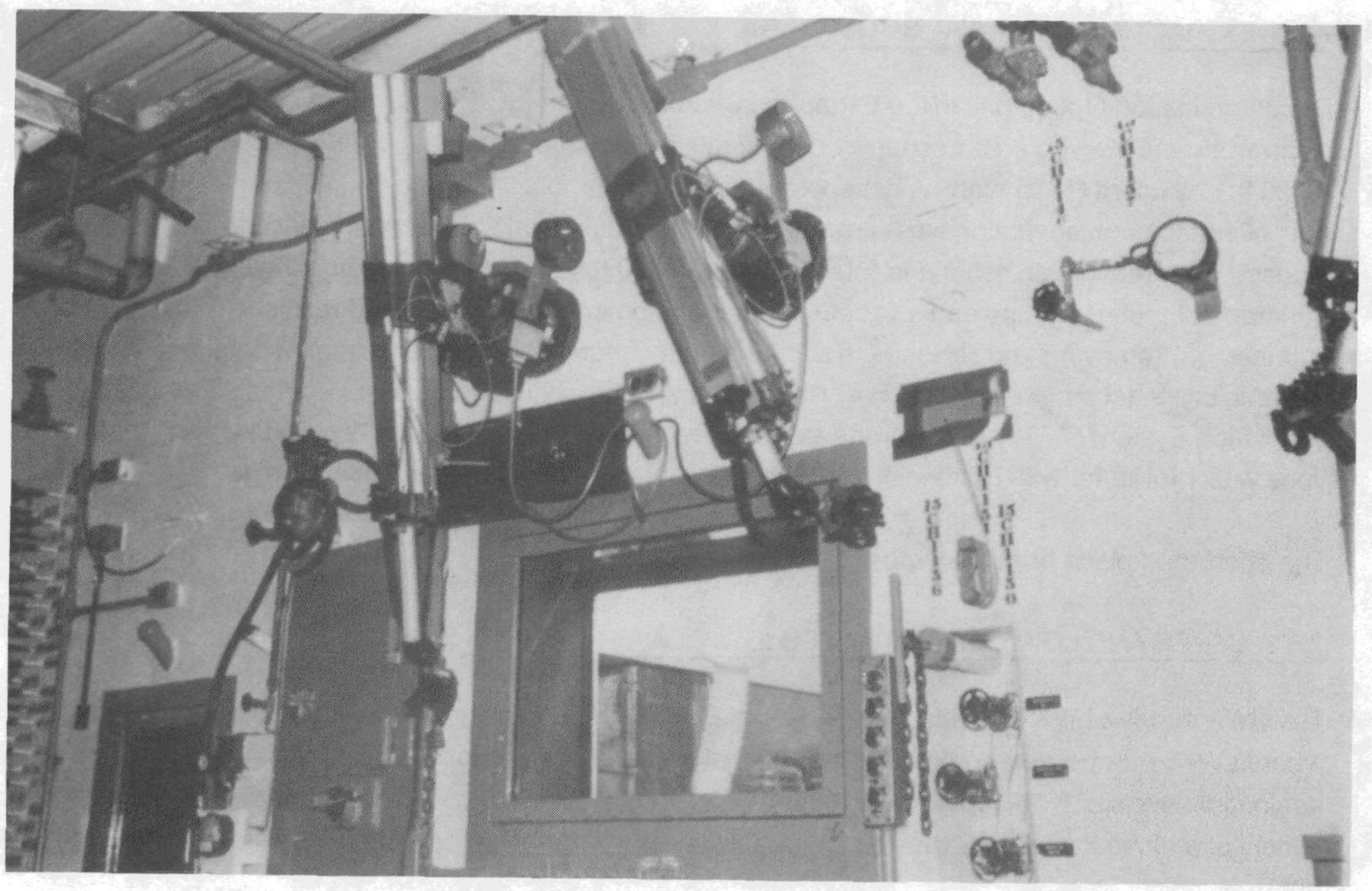

FIGURE 4

Refurblshed Analytical Cell Viewed from Analytical Alsie 
5. Decontamination Shop (north room of MSMRS) - Decontaminated and refurbished to house the Contact Size Reduction Facility (CSRF).

6. 01-14 Building - Minor decontamination to house the Cement Solidification System (CSS).

7. Other stairways, aisles and rooms were deconned as needed.

A brief discussion of the more extensive Decontamination Operations of these areas follows.

\subsubsection{EXTRACTION CHEMICAL ROOM (XCR)}

Decontamination Operations in the Extraction Chemical Room (XCR) were conducted to prepare a clean work and staging area to support decontamination of the extraction cells. The XCR is $279 \mathrm{~m}^{2}$

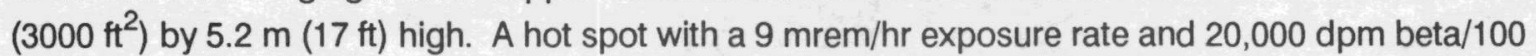
$\mathrm{cm}^{2}$ of surface contamination was present prior to decontamination. Decontamination of the XCR included: (1) removing an estimated total of $154 \mathrm{~m}^{3}\left(5440 \mathrm{ft}^{3}\right)$ of material including 27 tanks, 35 pumps, hundreds of meters of pipe and a variety of other equipment; (2) cleaning and refinishing wall and floor surfaces; (3) removing and replacing a section of the concrete floor; (4) erecting a containment tent over the cell hatches; (5) installing new lifting and handling equipment; and (6) adding a Temporary Ventilation System (TVS). The average exposure rate at the conclusion of Decontamination Operations was $1 \mathrm{mrad} / \mathrm{hr}$. with contamination levels less than contaminated area lower limits. ${ }^{[7]}$

The effort took place from December 1982 to April 1984.

\subsubsection{UPPER AND LOWER WARM AISLES (UWA, LWA)}

The UWA and the LWA were also needed for the LWTS installation since they contained pump niches where LWTS pumps were to be installed. An initial survey of a pump niche in the UWA indicated contamination levels of $3,500 \mathrm{dpm} / 100 \mathrm{~cm}^{2}$ alpha and $19,800 \mathrm{dpm} / 100 \mathrm{~cm}^{2}$ beta. A predecontamination survey of a niche in the LWA showed smearable levels $10^{5} \mathrm{dpm} / 100 \mathrm{~cm}^{2}$ alpha and $10^{6} \mathrm{dpm} / 100 \mathrm{~cm}^{2}$ beta.

Decontamination of the warm aisles included: (1) setting up containment and establishing ventilation over the niches; (2) pulling niche covers; (3) removing $45.3 \mathrm{~m}^{3}\left(1600 \mathrm{ft}^{3}\right)$ of radioactive waste such as pumps, valves, piping and instrumentation; (4) decontaminating niche interiors by vacuuming, applying and removing strippable paint and in one case, washing with acid; and (5) cleaning and painting outer niche areas.

The Decontamination Operations for the warm aisles took place from January 1985 to February 1986. Smearable levels were reduced to $<50 \mathrm{dpm} / 100 \mathrm{~cm}^{2}$ alpha and $<500 \mathrm{dpm} / 100 \mathrm{~cm}^{2}$ beta ${ }^{[8]}$. 


\subsubsection{EXTRACTION SAMPLE AISLE (XSA)}

The XSA is located between the lab facilities and the extraction cells and required the following Decontamination Operations: (1) decontaminating an air lock; (2) removing miscellaneous debris, trash, 152 $\mathrm{m}(500 \mathrm{ft})$ of piping, glove boxes, a catwalk and an air conditioner - a total waste volume of $27 \mathrm{~m}^{3}$ $\left(948 \mathrm{ft}^{3}\right)$; (3) decontaminating wall plates and wall surfaces; (4) floor scabbling; and (5) painting.

The effort took place from December 1985 and lasted until April 1986. Initial radiation levels were generally less than $1 \mathrm{mr} / \mathrm{hr}$ with a few hot spots of $10 \mathrm{mr} / \mathrm{hr}$ with smearable contamination ranging up to $3400 \mathrm{dpm} / 100 \mathrm{~cm}^{2}$ beta and $14,000 \mathrm{dpm} / 100 \mathrm{~cm}^{2}$ alpha on the glove boxes. After decontamination and painting, radiation levels were less than $1 \mathrm{mr} / \mathrm{hr}$ with contamination $<20 \mathrm{dpm} / 100 \mathrm{~cm}^{2}$ alpha and $<200 \mathrm{dpm} / 100 \mathrm{~cm}^{2}$ beta $^{[9]}$.

\subsubsection{MASTER SLAVE MANIPULATOR REPAIR SHOP (MSMRS)}

The MSMRS was decontaminated and refurbished so that it could continue to service and repair manipulators being used to support the Project. MSMRS Decontamination Operations included: (1) removing $39.7 \mathrm{~m}^{3}\left(1,400 \mathrm{ft}^{3}\right)$ of waste in the form of tools, MSMs and furnishings; (2) removing $24.5 \mathrm{~m}^{3}$ $\left(860 \mathrm{ft}^{3}\right)$ of concrete flooring; (3) vacuuming $\mathrm{f}$ all surfaces; (4) hot spot removal; (5) stripping and painting walls; (6) pouring a new concrete floor and installing a stainless-steel liner; and (7) adding shielding.

Radiation fields ranged from 5 to $300 \mathrm{mrad} / \mathrm{hr}$ and smearable surface contamination levels as high as $10^{5} \mathrm{dpm} / 100 \mathrm{~cm}^{2}$ beta. The post cleanup general area exposure rate was $\mathrm{mrad} / \mathrm{hr}$ with smearable levels $<100 \mathrm{dpm} / 100 \mathrm{~cm}^{2}$ beta.

This effort was completed between July 1982 and June $1983^{[10]}$. Figures 5 and 6 show the MSMRS during and after decontamination.

\subsubsection{CHEMICAL VIEWING AISLE (CVA)}

The CVA was decontaminated to allow safe entry into the Process Plant and to support Decontamination Operations in the CPC. The CVA operations included: (1) general wall and floor decon wipedown, (2) painting and (3) draining and refilling of shielding windows to restore optical clarity. This work was performed in 1983.

\subsubsection{DECONTAMINATION SHOP}

The Decon Shop was decontaminated to allow for the installation of a Contact Size Reduction Facility (CSRF). The CSRF would then size reduce and decontaminate vessels, piping and other scrap material. Materials handled here were limited to a surface exposure rate of less than $100 \mathrm{mr} / \mathrm{hr}$. Decontamination Operations conducted in the Decon Shop were: (1) the decontamination and removal of equipment; (2) constructing a concrete block addition on the north end of the MSM building; (3) install- 


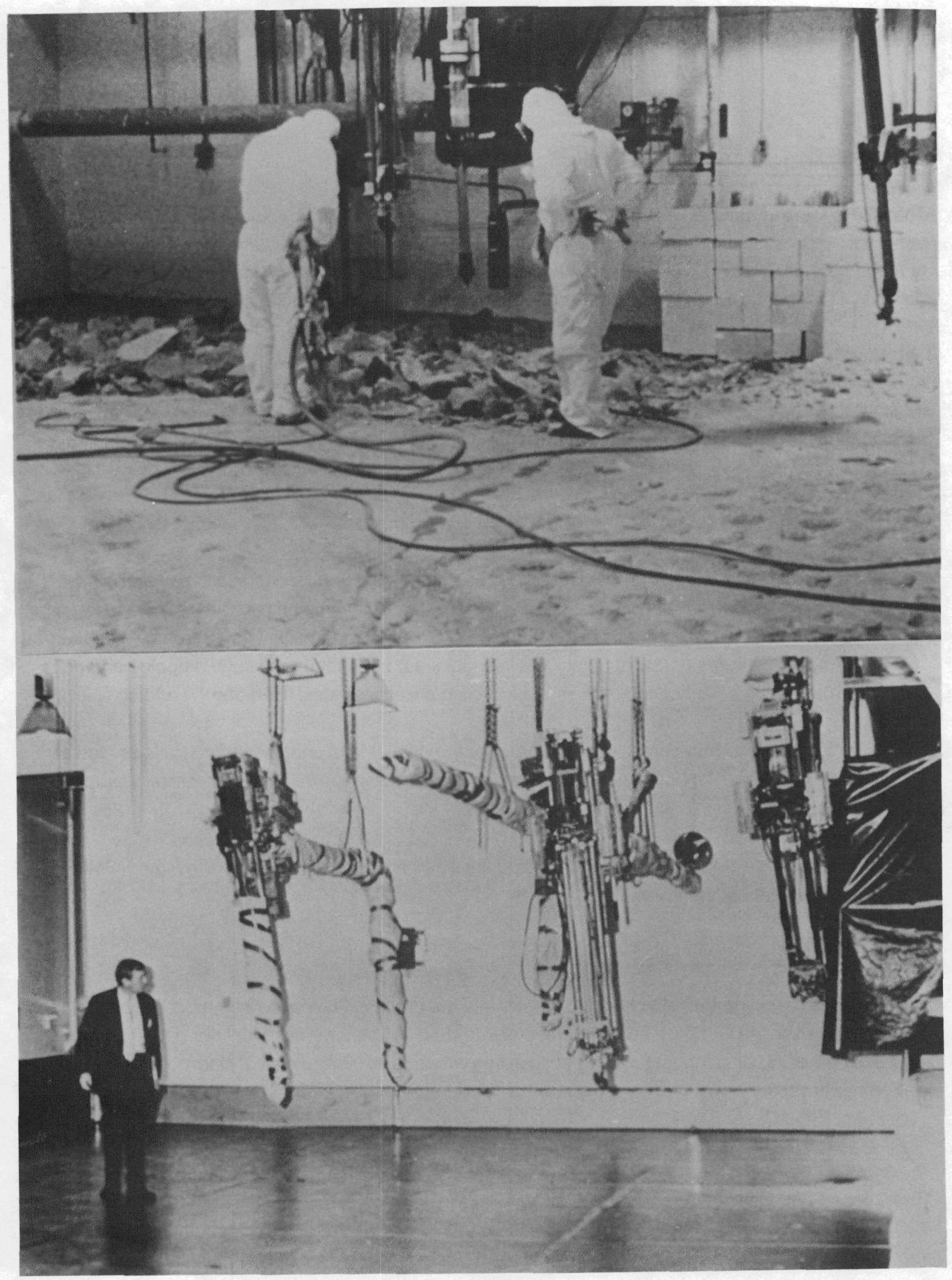

FIGURE 5 (TOD)

MSMRS During Decontamination

FIGURE 6 (Bottom)

MSMRs after Decontamination 
ing a partition wall and a stainless-steel skin in the cutting area; (4) installing ventilation, power, lighting and process equipment for waste handling and size reduction; and (5) removing contaminated concrete block for the installation of an observation window between the MSM shop and the cutting $\operatorname{area}^{[11]}$.

\subsubsection{1-14 BUILDING}

The 01-14 Building required minimal decontamination effort so that it could house the Cement Solidification System (CSS). Specifically, the acid fractioner cells in the 01-14 Building required decommissioning.

\subsection{MAJOR CELLS IN EXTRACTION AISLE}

To accomplish the Project's objective of solidifying HLW, a Liquid Waste Treatment System (LWTS) that processes liquid wastes was planned and constructed. Two major reprocessing cells, XC-3 and PPC, were identified to house the new LWTS equipment. The Uranium Product Cell (UPC) and the Uranium Loadout (ULO) were also identified for use as part of the LWTS.

\subsubsection{EXTRACTION CELL $3(X C-3)$}

The XC-3 contained 13 solvent extraction tanks, 8 columns, 2,200 meters ( $7300 \mathrm{ft}$ ) of piping and

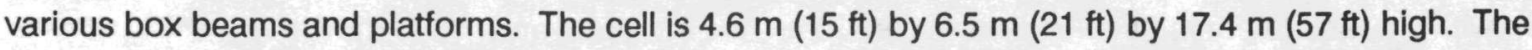
cell could be accessed by a 1.8 - $\mathrm{m}$-square $(6 \mathrm{ft}), 0.91$ - $\mathrm{m}$-thick $(3 \mathrm{ft}$ ) concrete hatch in the ceiling or by a personnel access door at the base.

An initial survey showed radiation levels of $5 \mathrm{mr} / \mathrm{hr}$ at higher elevations with floor readings up to 150 $\mathrm{mr} / \mathrm{hr}$ beta and gamma, smearable contamination levels greater than $10^{6} \mathrm{dpm} / 100 \mathrm{~cm}^{2}$ alpha and airborne concentration levels greater than 40,000 times the maximum permissible concentration (MPC) for alpha. The decontamination of XC-3 was accomplished exclusively by manned entries from July 1983 to April 1985. All personnel wore multiple layers of anticontamination clothing using respirators and forced breathing air (bubble hoods). After decontamination and painting, radiation levels were .0 $\mathrm{mr} / \mathrm{hr}$ and contamination levels were $<50 \mathrm{dpm} / 100 \mathrm{~cm}^{2}$ alpha and $<500 \mathrm{dpm} / 100 \mathrm{~cm}^{2}$ beta $^{[12]}$.

Because of the labor-intensive effort required, the radiological protection requirements, the amount of waste generated a volume of $244 \mathrm{~m}^{3}\left(8600 \mathrm{ft}^{3}\right)$ and the restricted access to the tall cell, decontamination of XC-3 is thought by many to be one of the most significant decontamination accomplishments at the WVDP. Figure 7, a model of XC-3, was helpful in visualizing its contents and was used to plan Decontamination Operations. Figure 8 shows a vessel being removed. Figure 9 shows an LWTS vessel in XC-3, after cleanup.

Figure 10 shows the two-man work platform (spider) used to gain access to all elevations of XC-3. The "spider" was suspended through the ceiling hatch from a 4.54-ton Gantry beam. The platform could be 
controlled from the platform by an operator or, in case of an emergency, a backup operator above the cell. A full-body, parachute-type harness was connected from each cell worker to a winch lifeline. The lifeline was tended by a support person at all times.

\subsubsection{PRODUCT PURIFICATION CELL (PPC)}

The PPC housed 24 purification vessels, various product evaporators and storage tanks and $2130 \mathrm{~m}$ $(7,000 \mathrm{ft})$ of piping. The cell, like XC-3, could be accessed through a ceiling hatch and a personnel access door from the Uranium Product Cell (UPC) at its base.

Initial radiation surveys indicated average levels up to $60 \mathrm{mr} / \mathrm{hr}$ beta/gamma and floor readings as high as $175 \mathrm{mr} / \mathrm{hr}$ beta/gamma. Smearable contamination levels were greater than $1.75 \mathrm{E}+6 \mathrm{dpm} / 100 \mathrm{~cm}^{2}$ alpha and $5.00 \mathrm{E}+5 \mathrm{dpm} / 100 \mathrm{~cm}^{2}$ beta/gamma. Isolated radiation levels of 400 to $700 \mathrm{mr} / \mathrm{hr}$ were found on the bottom of two storage tanks in the cell.

A commercially available hydraulic arm was modified, outfitted with tools, tested and used to remotely accomplish much of the pipe cutting. This decreased personnel exposures and increased productivity for subsequent manned entries.

The decontamination of PPC lasted from March 1984 to January 1986 and the total waste volume generated was $199.5 \mathrm{~m}^{3}\left(7,045 \mathrm{ft}^{3}\right)^{[13]}$. After decontamination and painting, radiation levels averaged 1 $\mathrm{mr} / \mathrm{hr}$ with smearable contamination levels $<50 \mathrm{dpm} / 100 \mathrm{~cm}^{2}$ alpha and $<500 \mathrm{dpm} / 100 \mathrm{~cm}^{2}$ beta/gamma. Air samples showed alpha activity had decreased from 84,600 MPC to less than 1. Figure 11 shows the hydraulic arm in use.

Decontamination Operations in both XC-3 and PPC included: (1) cutting and removing contaminated piping, vessels and structures using a work platform; (2) collecting debris and trash from floor; (3) solidifying debris in cement, (4) removing solidified debris and trash; (5) alkaline foam cleaning and water rinsing of interior surfaces; and (6) painting.

\subsubsection{PRODUCT HANDLING AREA (PHA)}

The PHA consisted of the Uranium Product Cell (UPC) and the Uranium Loadout Area (ULO). These areas were decontaminated to be part of the LWTS. The UPC was identified as important because it provided access to the bottom of the PPC and it contained large tanks suitable for use as LWTS components.

The UPC was more contaminated than the ULO. Radiation levels were generally less than $1 \mathrm{mr} / \mathrm{hr}$ with maximum smearable contamination levels of $288,000 \mathrm{dpm} / 100 \mathrm{~cm}^{2}$ alpha and $133,000 \mathrm{dpm} / 100 \mathrm{~cm}^{2}$ beta/gamma. At the completion of decontamination, contamination levels for both the UPC and ULO were $<20 \mathrm{dpm} / 100 \mathrm{~cm}^{2}$ alpha and $<200 \mathrm{dpm} / 100 \mathrm{~cm}^{2}$ beta/gamma. 


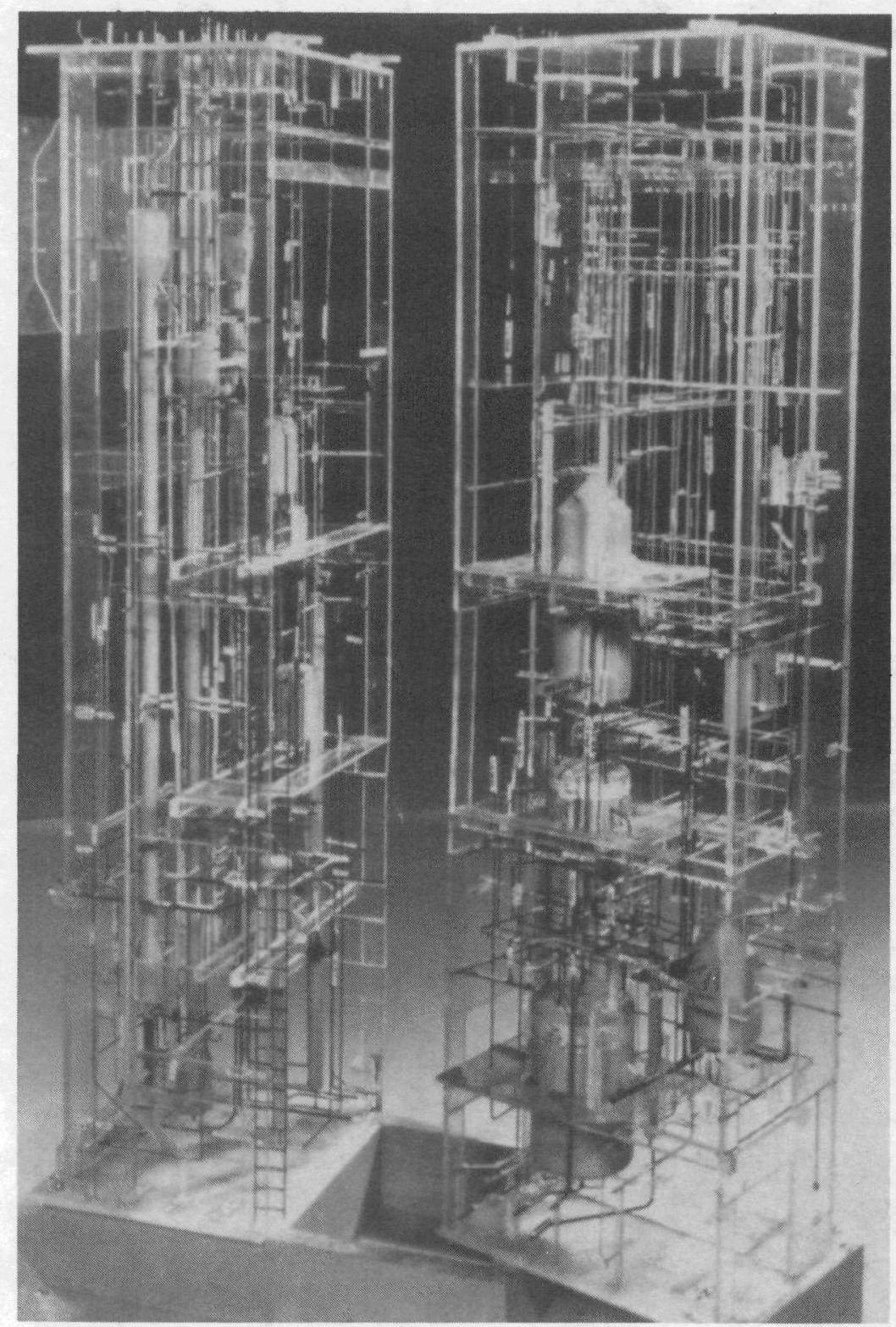

FIGURE 7

Scale Model of XC-3

Used to Prepare Decontamination Procedures 


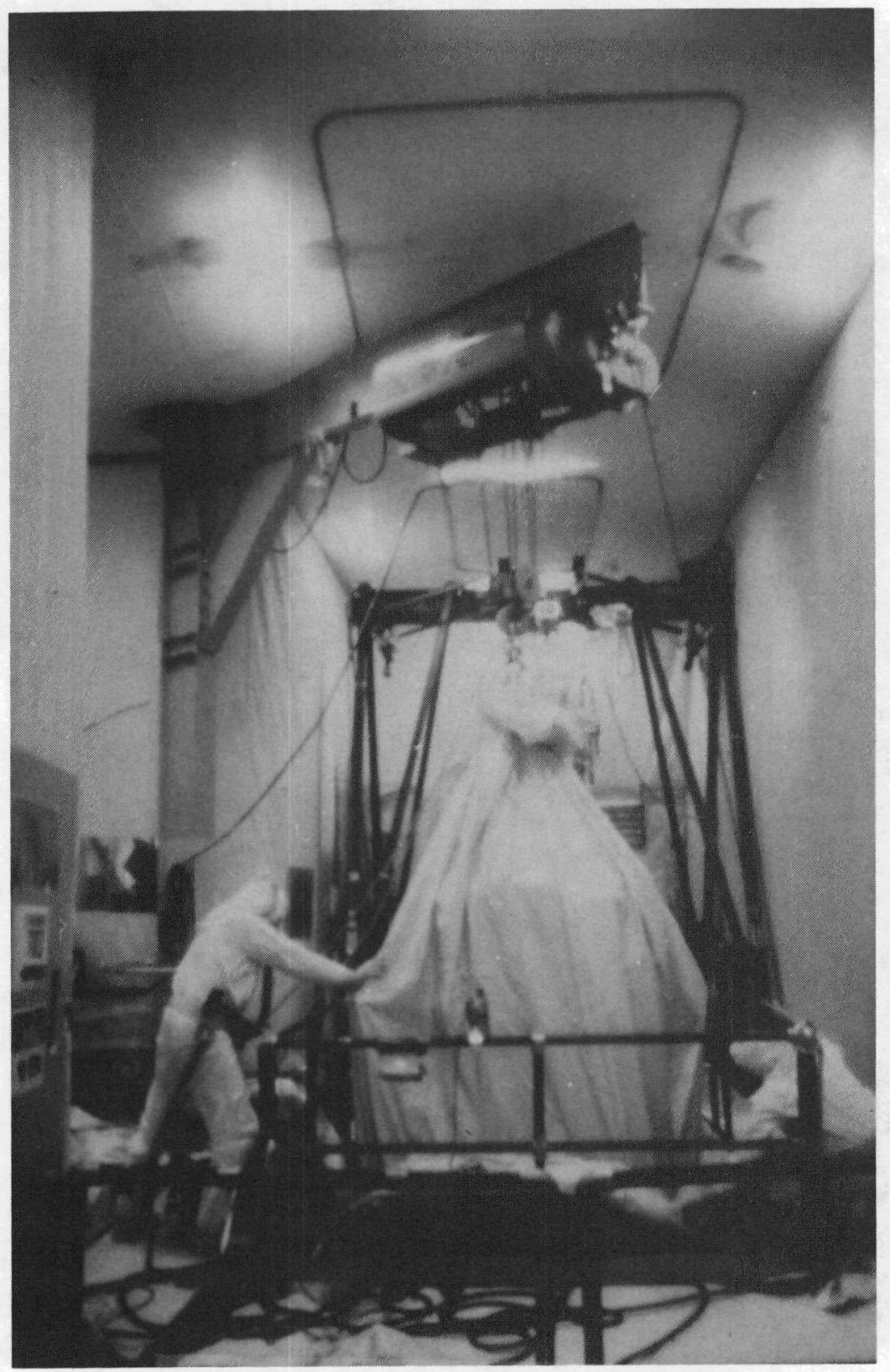

FIGURE 8

Vessel Being Removed from XC-3 During Cleanup 


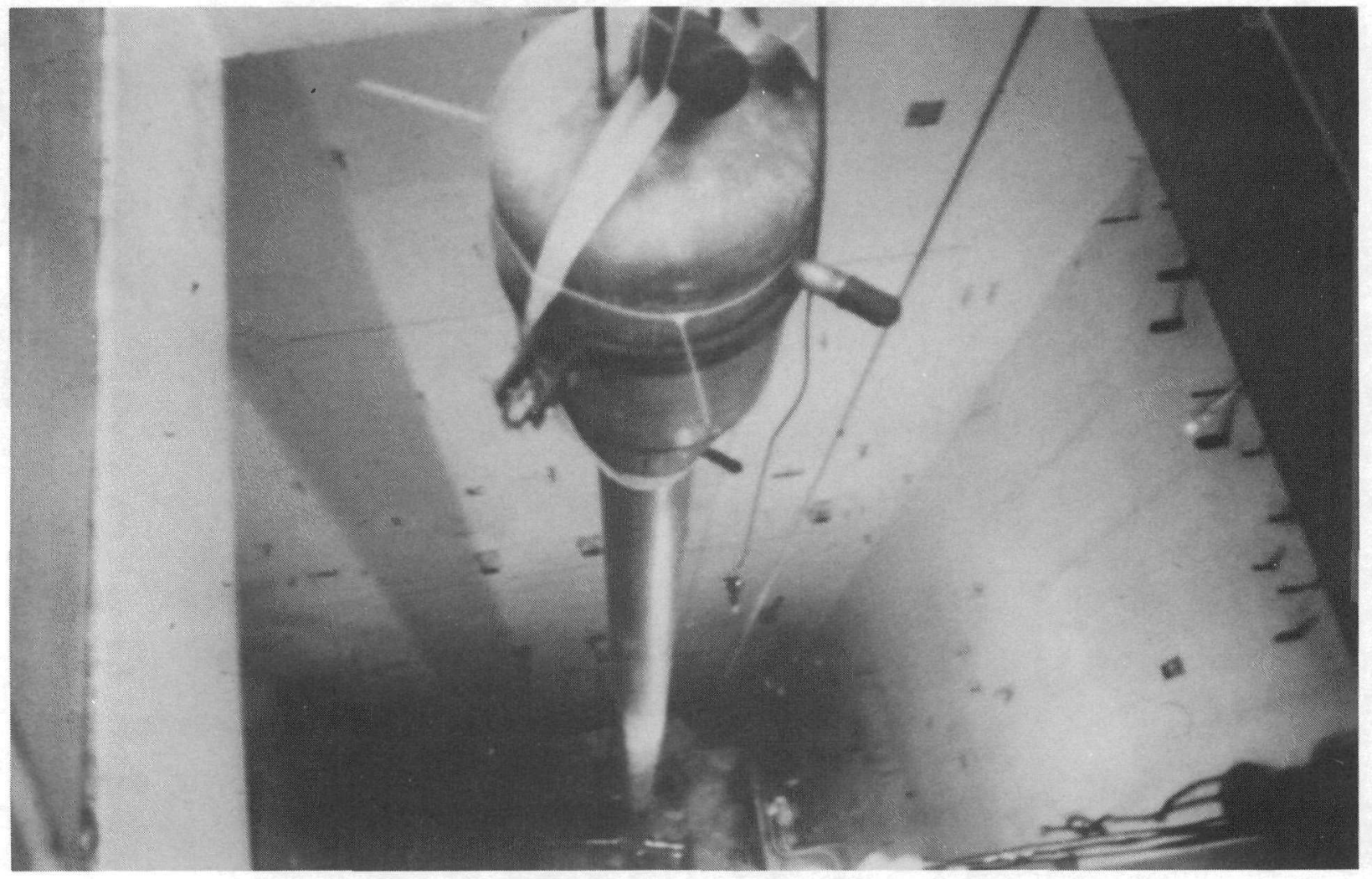

FIGURE 9

LWTS Vessel Being Installed In XC-3 After Cleanup 


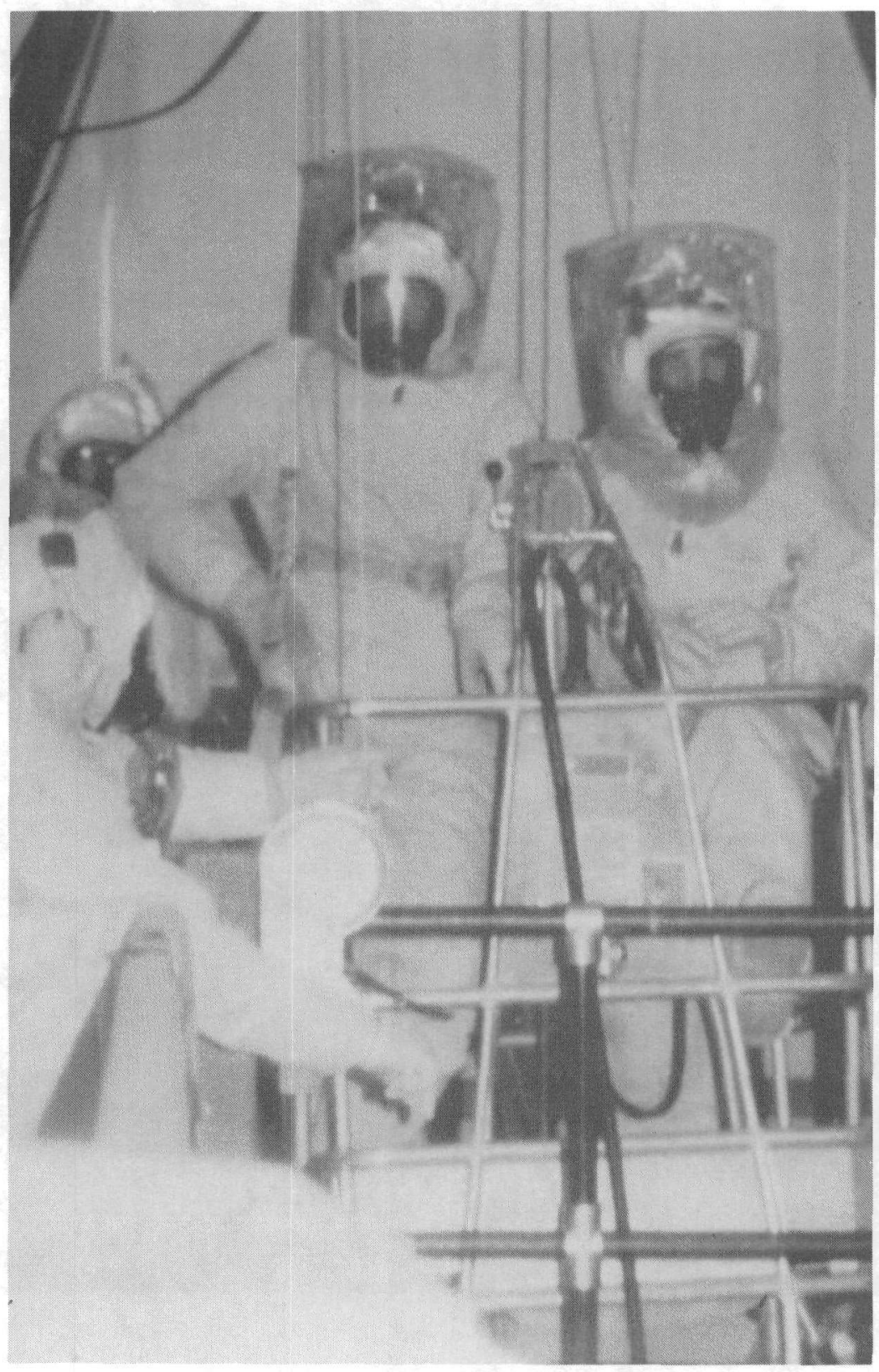

FIGURE 10

"Spider" Work Plattorm 


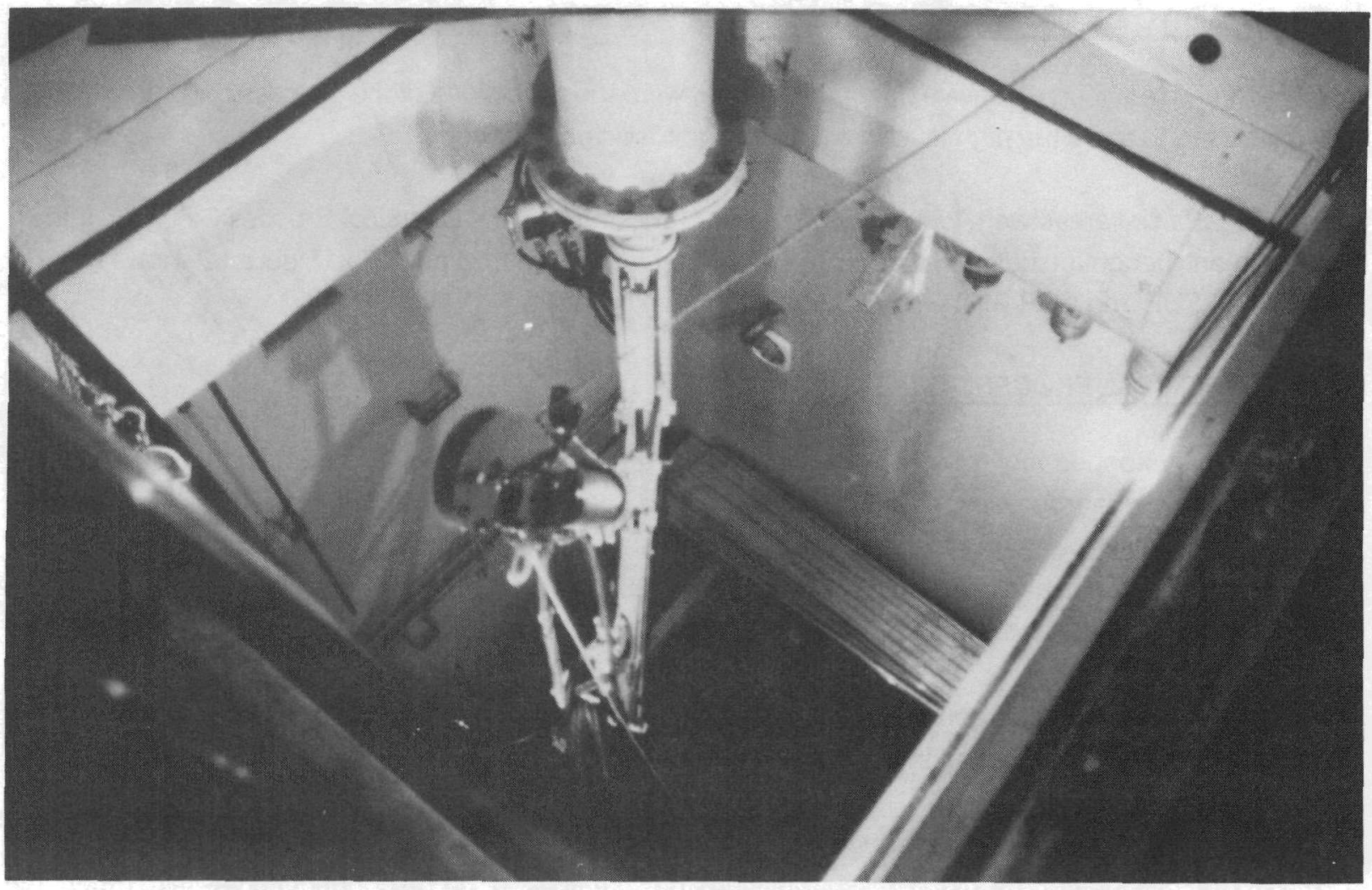

FIGURE 11

Hydraullc Arm Used in PPC 
Decontamination Operations for these two areas included: (1) some equipment and piping removal; (2) washing and, in some instances, paint removal to decontaminate surfaces; (3) draining sumps; (4) removing pump niches; (5) repainting; (6) laying rubber matting; and (7) replacing a stainless-steel ledge covering.

PHA Decontamination Operations began in July 1985 and were completed in February 1986. A total of $39.25 \mathrm{~m}^{3}\left(1386 \mathrm{ft}^{3}\right)$ of waste was generated ${ }^{[14]}$.

\subsection{CELLS TO BE USED FOR VITRIFICATION}

Other areas requiring extensive decontamination, were those portions of the process building which will be used to store the high-level waste (HLW) borosilicate glass logs.

Three major cell areas were identified for interim HLW storage: the Chemical Process Cell (CPC), the Equipment Decontamination Room (EDR) and Chemical Crane Room (CCR). Figure 12 shows how the CPC, EDR and CCR will be joined to the Vitrification Facility.

\subsubsection{CHEMICAL PROCESS CELL (CPC)}

In the CPC, chopped fuel was chemically dissolved. Because of high levels of radiation expected in the $\mathrm{CPC}$ during reprocessing operations, the $\mathrm{CPC}$ was designed with Hanford-style quick connectors. These connectors can be completely disassembled and changed remotely. The cell contained 17 major vessels (tanks and dissolvers), over $450 \mathrm{~m}$ (1500 ft) of jumpers/pipes, miscellaneous support racks and structures and three $20,000 \mathrm{~kg}(22.5 \mathrm{ton})$ concrete pedestals.

An initial survey indicated general radiation fields of 10 to $60 \mathrm{r} / \mathrm{hr}$ with typical vessel hotspots of $100 \mathrm{r} / \mathrm{hr}$ and smearable contamination in excess of $10^{9} \mathrm{dpm} / 100 \mathrm{~cm}^{2}$ beta.

The major cell operations involved: (1) vacuuming the cell floor, (2) applying foamed cleaning chemicals to the cell interior, (3) high-pressure rinsing and scarification, (4) disconnecting vessels, (5) cutting cell piping, (6) cutting and removing three concrete pedestals and (7) loading waste into boxes and transferring waste out for storage.

Final decontamination results obtained were general dose rates between $200 \mathrm{mr} / \mathrm{hr}$ and $1200 \mathrm{mr} / \mathrm{hr}$ with smearable contamination levels of 50,000 to $300,000 \mathrm{dpm} / 100 \mathrm{~cm}^{2}$ beta. Over $850 \mathrm{~m}^{3}\left(30,000 \mathrm{ft}^{3}\right)$ of primary waste was packed into 22 containers as large as $3.4 \mathrm{~m}(11 \mathrm{ft})$ by $3.4 \mathrm{~m}(11 \mathrm{ft})$ by $6.1 \mathrm{~m}(20$ $\mathrm{ft}$ ). Sixty-three $2.5-\mathrm{m}^{3}$ boxes $\left(88 \mathrm{ft}^{3}\right)$, twenty-nine 208 -liter (55-gallon) drums and many $1.8 \mathrm{~m}(6 \mathrm{ft})$ by $1.8 \mathrm{~m}(6 \mathrm{ft})$ by $3.6 \mathrm{~m}(12 \mathrm{ft})$ boxes of secondary waste were also generated in the decontamination of the CPC. All Decontamination Operations were performed remotely utilizing two overhead cranes, an electromechanical manipulator and a 6-wheel mobile robot[15]. Figure 13 shows the CPC before and 


\section{INTERIM STORAGE FACILITY}

\section{VITRIFICATION CELL}

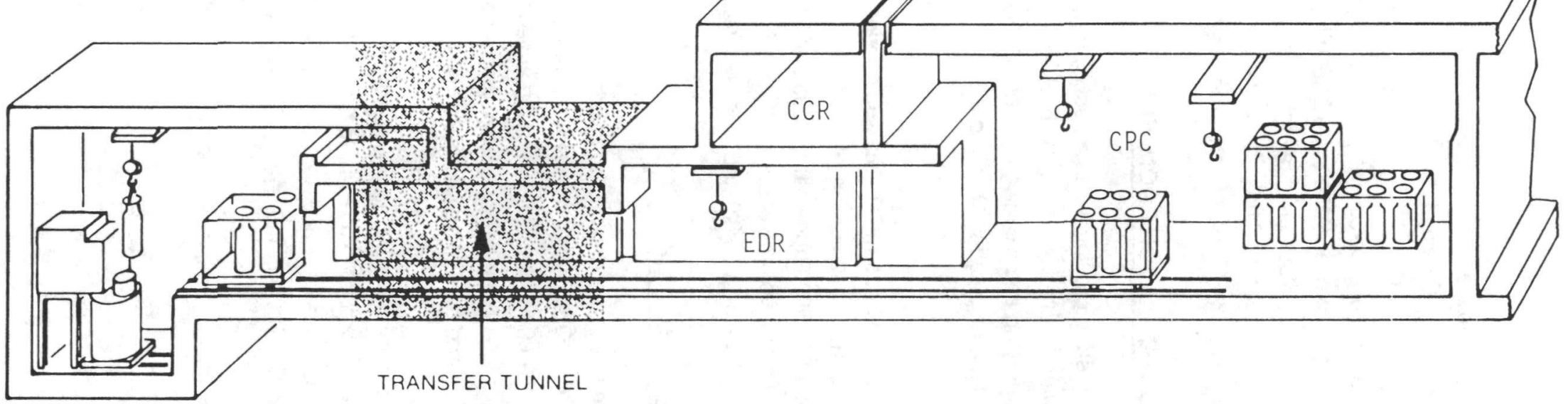


after decontamination. Decontamination of the CPC began in January 1985. Vessel removal and clean-up to $\mathrm{d} \mathrm{mr} / \mathrm{hr}$ was completed in March 1987.

The decontamination of the CPC presented many difficult engineering challenges. Of particular interest was the remote cutting and removal of the three $20,000 \mathrm{~kg}$ (22.5 ton) reinforced concrete pedestals. The manipulator was used to place an ultra high-pressure (UHP) water-abrasive cutting nozzle and its tracking device, over a pedestal. The pedestal was then cut, cracked and tipped onto a transfer car using a tipping fixture and a $14,500 \mathrm{~kg}$ (16 ton) crane (figure 14).

\subsubsection{EQUIPMENT DECONTAMINATION ROOM (EDR)}

The EDR was decontaminated to provide a waste packaging and transfer area for decontaminating the CPC. Decontamination was accomplished by: (1) packaging and removal of wastes, (2) grinding concrete floor surfaces, (3) emptying and cleaning soaking pit, (4) washing and painting the walls and (5) refurbishing the utilities. Decontamination Operations also included refurbishing the transfer car and load testing the cranes.

Decontamination was initiated in September 1983 and continued until May 1985. Average radiation fields were reduced from $90 \mathrm{mr} / \mathrm{hr}$ to $29 \mathrm{mr} / \mathrm{hr}$. Smearable contamination levels were reduced from $4,100 \mathrm{dpm} / 100 \mathrm{~cm}^{2}$ alpha and $57,000 \mathrm{dpm} / 100 \mathrm{~cm}^{2}$ beta to $<20 \mathrm{dpm} / 100 \mathrm{~cm}^{2}$ alpha and $<200$ $\mathrm{dpm} / 100 \mathrm{~cm}^{2}$ beta. A total waste volume of $62.5 \mathrm{~m}^{3}\left(2210 \mathrm{ft}^{3}\right)$ was generated and packed into 143 drums with a capacity of $0.2 \mathrm{~m}^{3}\left(7.5 \mathrm{ft}^{3}\right)$ and 13 boxes with a capacity of $2.5 \mathrm{~m}^{3}\left(88 \mathrm{ft}^{3}\right)^{[16]}$.

\subsubsection{CHEMICAL CRANE ROOM (CCR)}

The CCR was used for the storage and servicing of bridge cranes and an electromechanical manipulator used in the CPC. Operations involved: (1) removing air lock surface contamination, (2) establishing containment, (3) vacuum cleaning, (4) damp wipedown, (5) floor and wall surface grinding, (6) grinding and acid descaling of crane rail surfaces (unsuccessful in significantly reducing embedded contamination), (7) painting and (8) adding rail shielding.

CCR operations began in December 1982 and were completed in April 1983. General exposure rates were reduced from between 5 and $2000 \mathrm{mrad} / \mathrm{hr}$ to 5 to $200 \mathrm{mrad} / \mathrm{hr}$. Smearable levels were reduced from $7,400 \mathrm{dpm} / 100 \mathrm{~cm}^{2}$ alpha and $374,000 \mathrm{dpm} / 100 \mathrm{~cm}^{2}$ beta to $600 \mathrm{dpm} / 100 \mathrm{~cm}^{2}$ alpha and 62,000 $\mathrm{dpm} / 100 \mathrm{~cm}^{2}$ beta. Forty-nine 208 -liter (55-gallon) drums of waste were removed from the $\mathrm{CCR}^{[17]}$.

Table 3 indicates the area, cost and exposure for the CPC, EDR and CCR. 


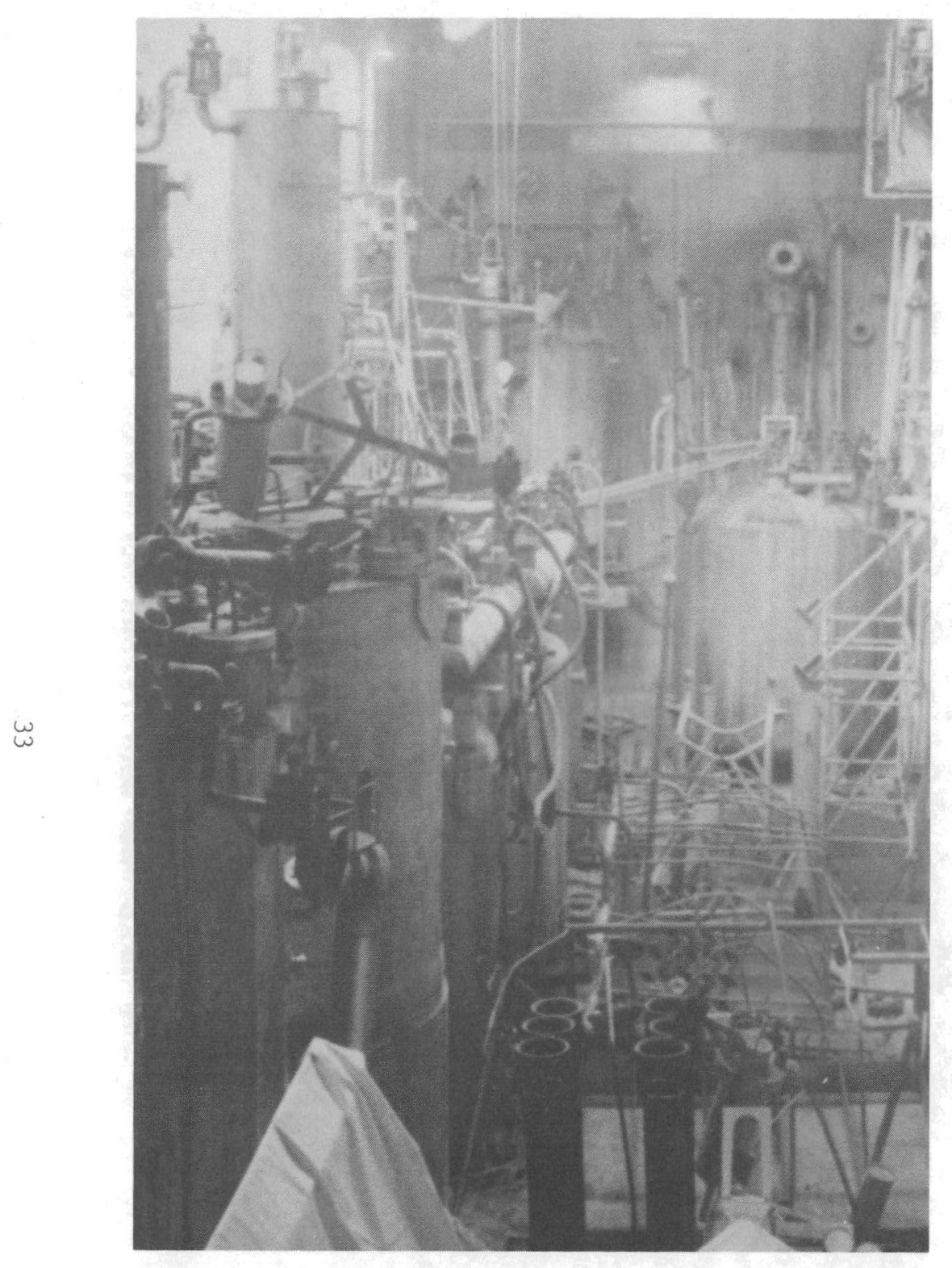

CPC - Before Decontamination
FIQURE 13

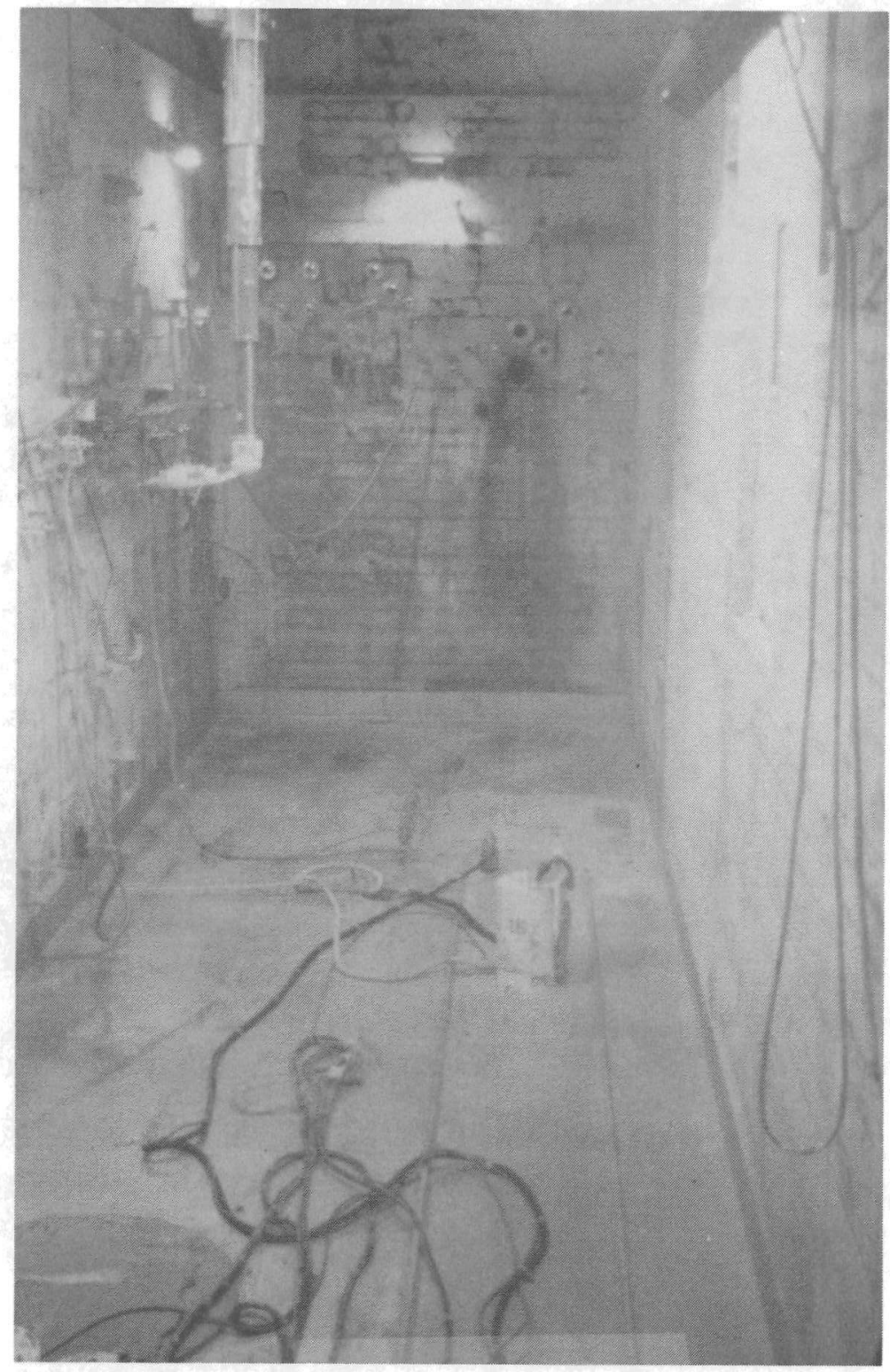

CPC - After Decontamination 


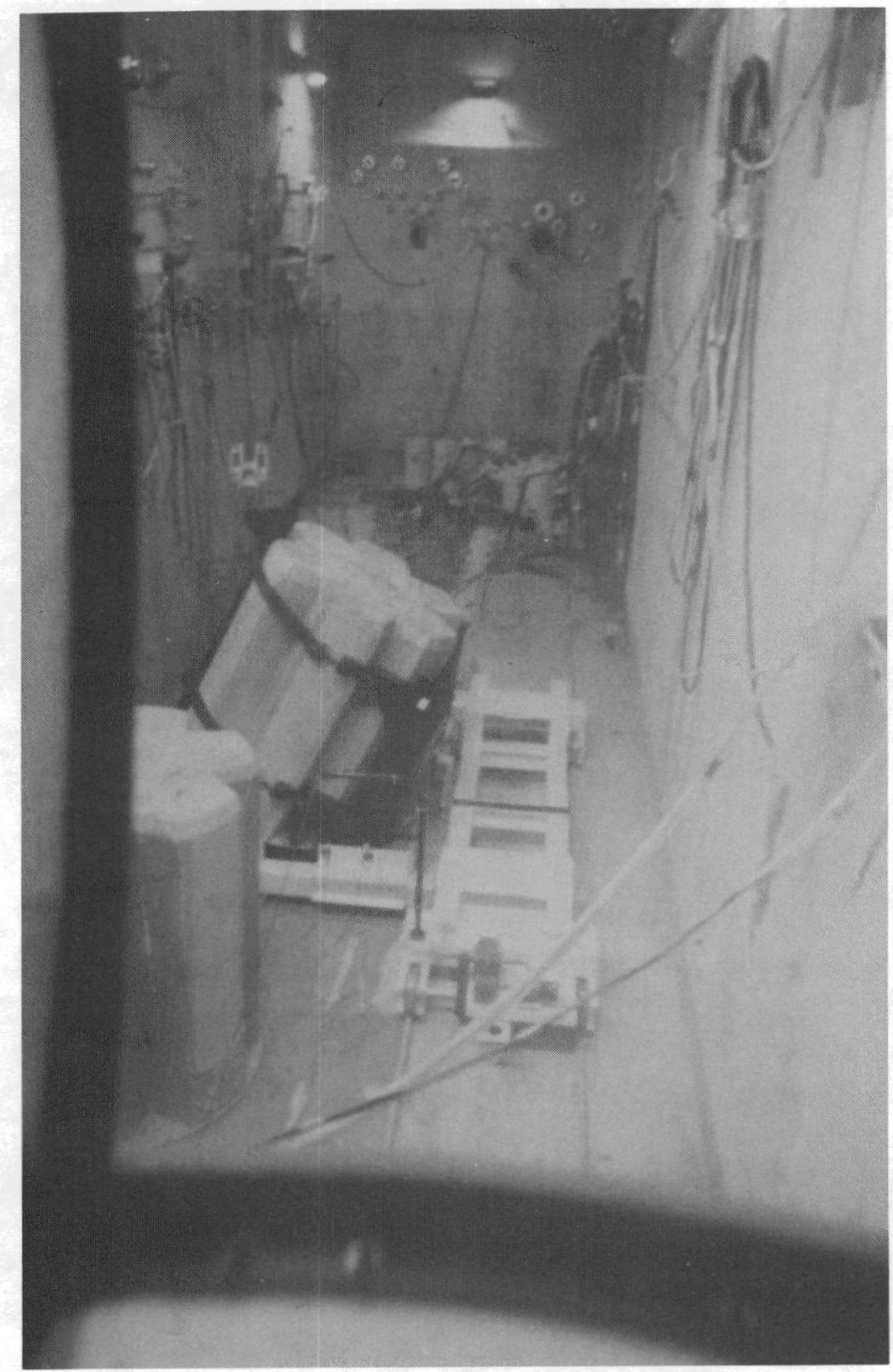

FIGURE 14

Using Tipping Fixture and Crane

to TIp Pedestal onto Transfer Car in GPC 
Table 3: Summary of Areas. Costs and Exposures for Decontamination of Plant Locations for HighLevel Waste Storage

$\begin{array}{cccc}\text { Area (m2) } & \text { Area Location } & \text { Cost (Thousand \$) } & \text { Exposure (Man-rem) } \\ \text { CPC } & 220 & 2200 & 11.4 \\ \text { EDR } & 117 & 1422 & 7.7 \\ \text { CCR } & 56 & 174 & 2.2 \\ \text { Total } & 393 & 3796 & 21.3\end{array}$

\subsection{HIGH-LEVEL WASTE (HLW) TANK FARM}

High-level waste (HLW) was generated during the reprocessing of spent nuclear fuel between 1966 and 1972. The HLW tank farm consists of Tanks 8D-1, 8D-2, 8D-3 and 8D-4. Tank 8D-2 contains approximately $2,270,000$ liters $(600,000$ gallons) of high-level liquid waste. Tank $8 D-1$ is an identical spare tank for $8 \mathrm{D}-2$ which was never used to accept waste. Both tanks are located underground surrounded

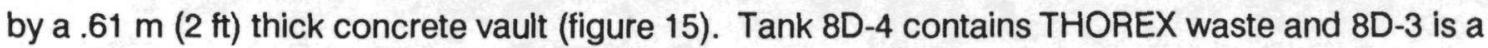
spare. These are both stainless-steel, but not discussed further in this report.

\subsubsection{SUPERNATANT TREATMENT SYSTEM (STS)}

Ninety percent of the 2,270,000 liters (600,000 gallons) of HLW inside underground Tank $8 D-2$ is a clear liquid called supernatant. The remaining 10 percent is a dense sludge-like material. The supernatant is currently being processed in the STS to remove greater than 99.9 percent of the Cs-137 through an ion exchange process. STS ion exchange columns filled with zeolite were installed in the spare HLW Tank (8D-1) as were filters, pumps and other STS components. After supernatant processing is completed, the ion exchange zeolite resin will be transferred to the vitrification system for incorporation into glass logs.

\subsubsection{SLUDGE MOBILIZATION SYSTEM (SMS)}

Both HLW tanks (8D-1 and 8D-2) are reinforced by an intricate network of steel plates, girders and posts. The sludge has settled on the reinforced floor.

The function of the SMS is to: (1) break up, mix, homogenize and wash the sludge and (2) transport the liquid to the STS ion exchange system and the sludge to the Vitrification Facility.

Due to a radiation field of $350 \mathrm{rem} / \mathrm{hr}$ at the top of Tank $8 \mathrm{D}-2$, the installation of pump supports (called risers) was performed remotely ${ }^{[18]}$. Tank $8 D-1$, with a low radiation level, was used to train personnel and to test the operation of the remote equipment. 


\section{HIGH-LEVEL LIQUID WASTE TANK}

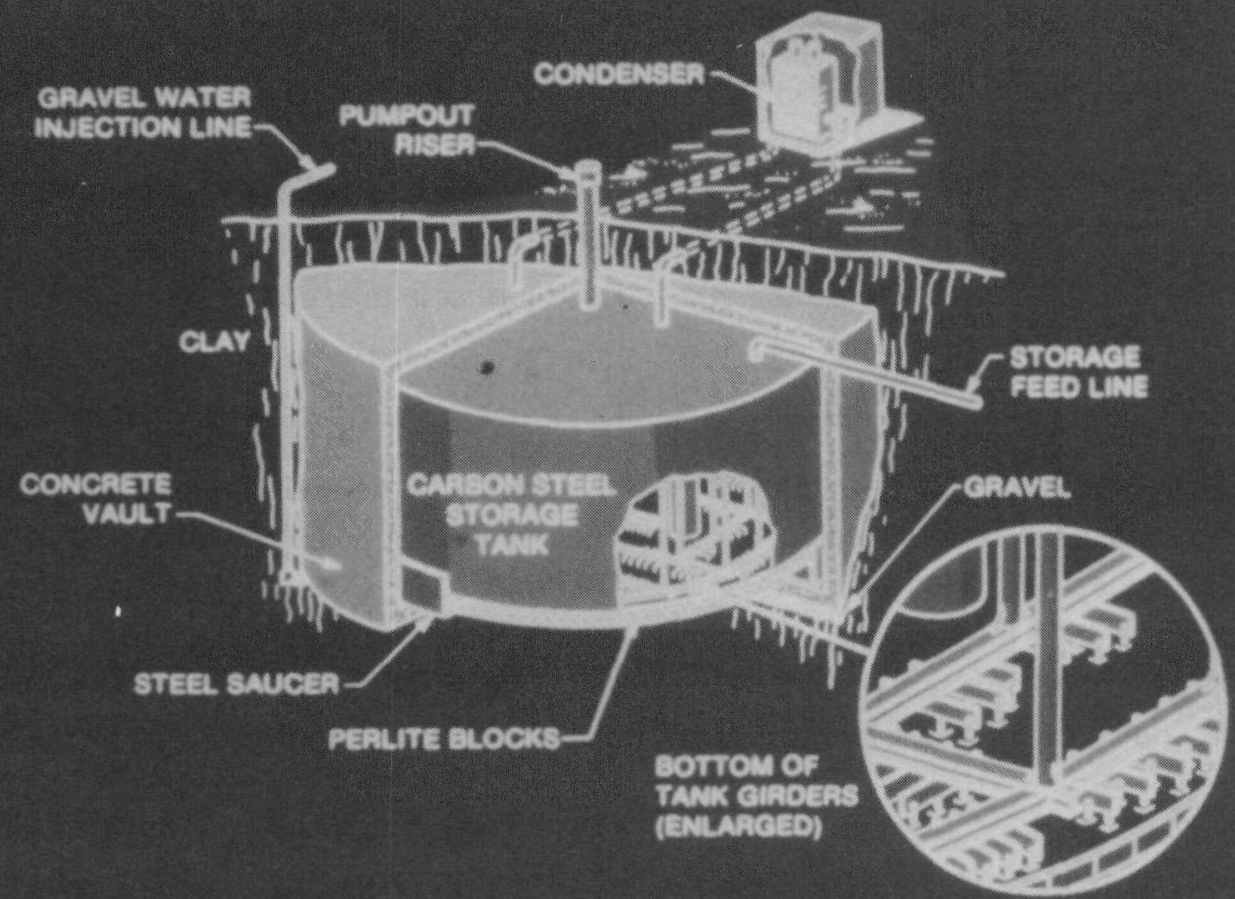

FIGURE 15

HLW Tank 
The installation of the risers consisted of: (1) evaluating the tank, (2) sampling, (3) removing soil, (4) installating the truss, (5) establishing a work area by installing a construction caisson, (6) core drilling a 0.76-m-diameter (30 in.) hole through the concrete roof, (7) cutting and removing two interfering roof rafters, (8) grinding a uniform circle on the tank top to prepare it for riser welding, (9) welding the riser to the top of the tank, (10) pressure-testing the weld, (11) welding a load transfer device to the riser, (12) cutting through the tank roof and (13) installing a shield plug in the riser.

During operations on the tanks, a number of precautions were used to minimize work force exposure to ALARA levels. The precautions included:

- using radiation work permits to restrict the number of personnel and stay times for workers at the site

- enforcing daily exposure limits of $100 \mathrm{mr}$ per person

- setting up special shielding

- daily prejob briefings

- management walk-throughs and readiness reviews

- constant coverage of operations by radiological control technicians

The above precautions, along with the use of remote equipment (designed and built by Westinghouse and Rockwell Hanford Operations) resulted in low radiation exposure to personnel. The actual radiation exposure totaled 3.441 rem for all personnel while the original total estimate was $4.3 \mathrm{rem}^{[18]}$.

Installation of the risers is shown in figures 16,17 and 18. 


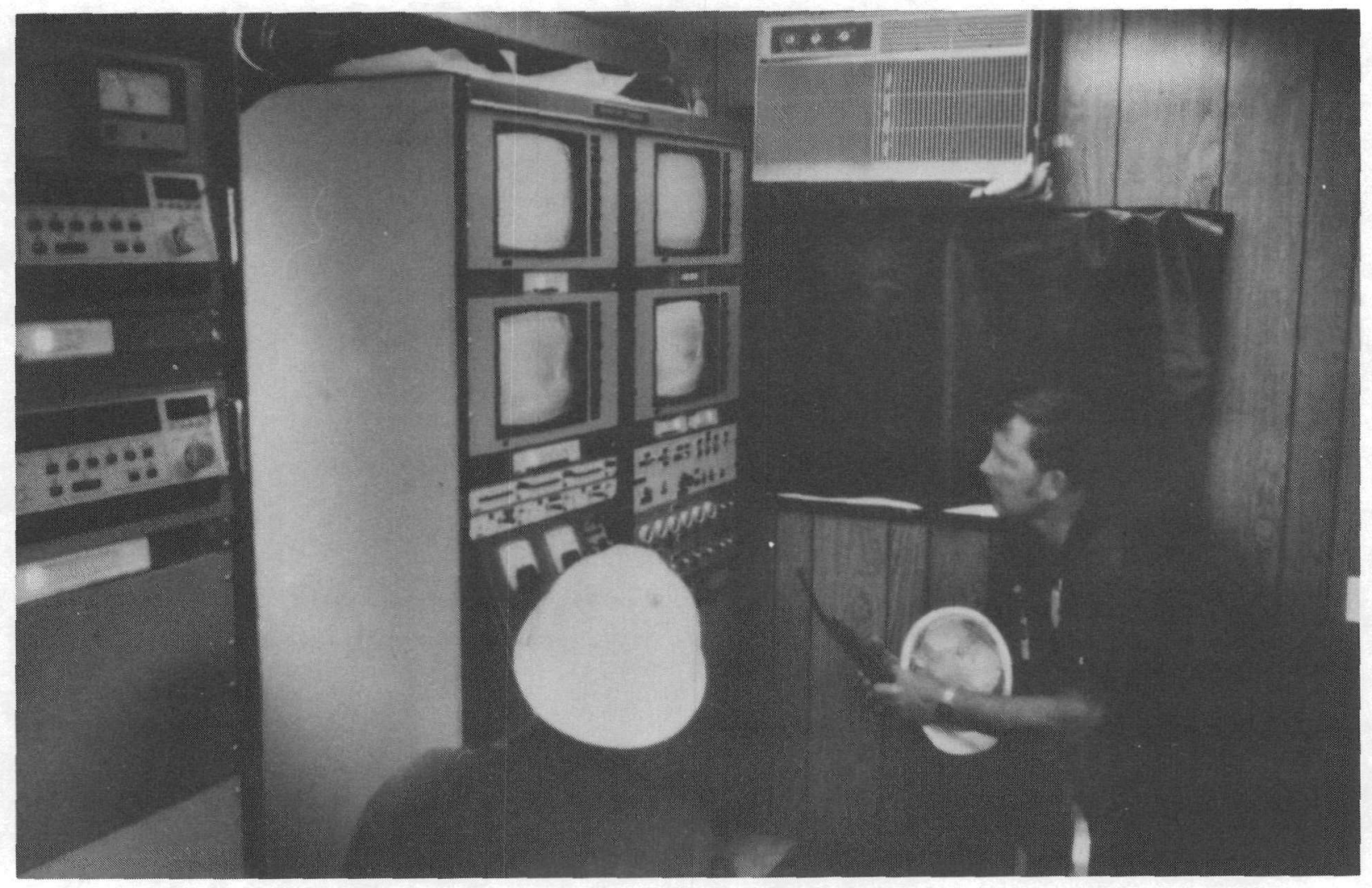

FIGURE 16

Remote Controls for Riser Installation 


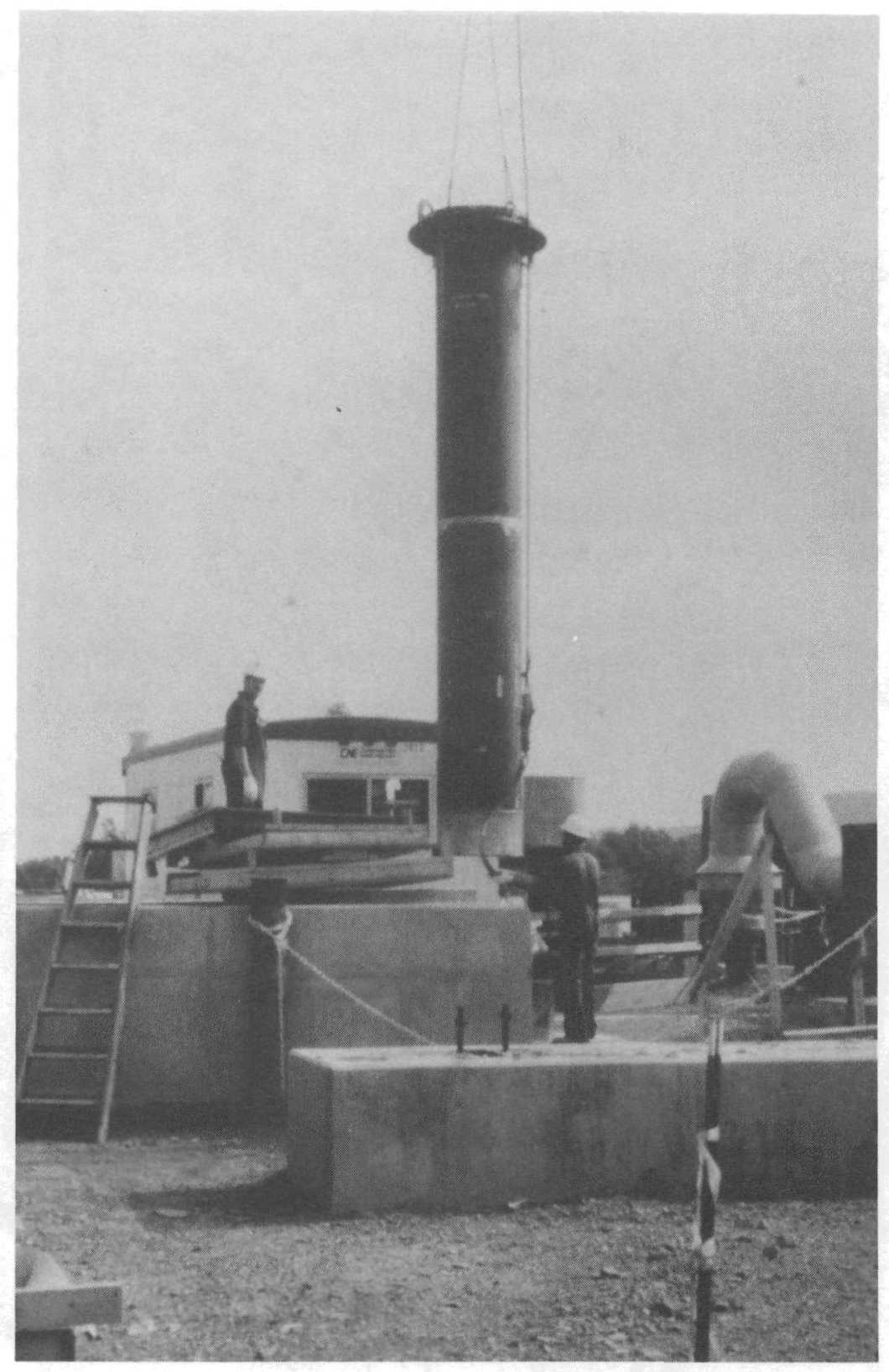

FIGURE 17

Riser Being Installed 


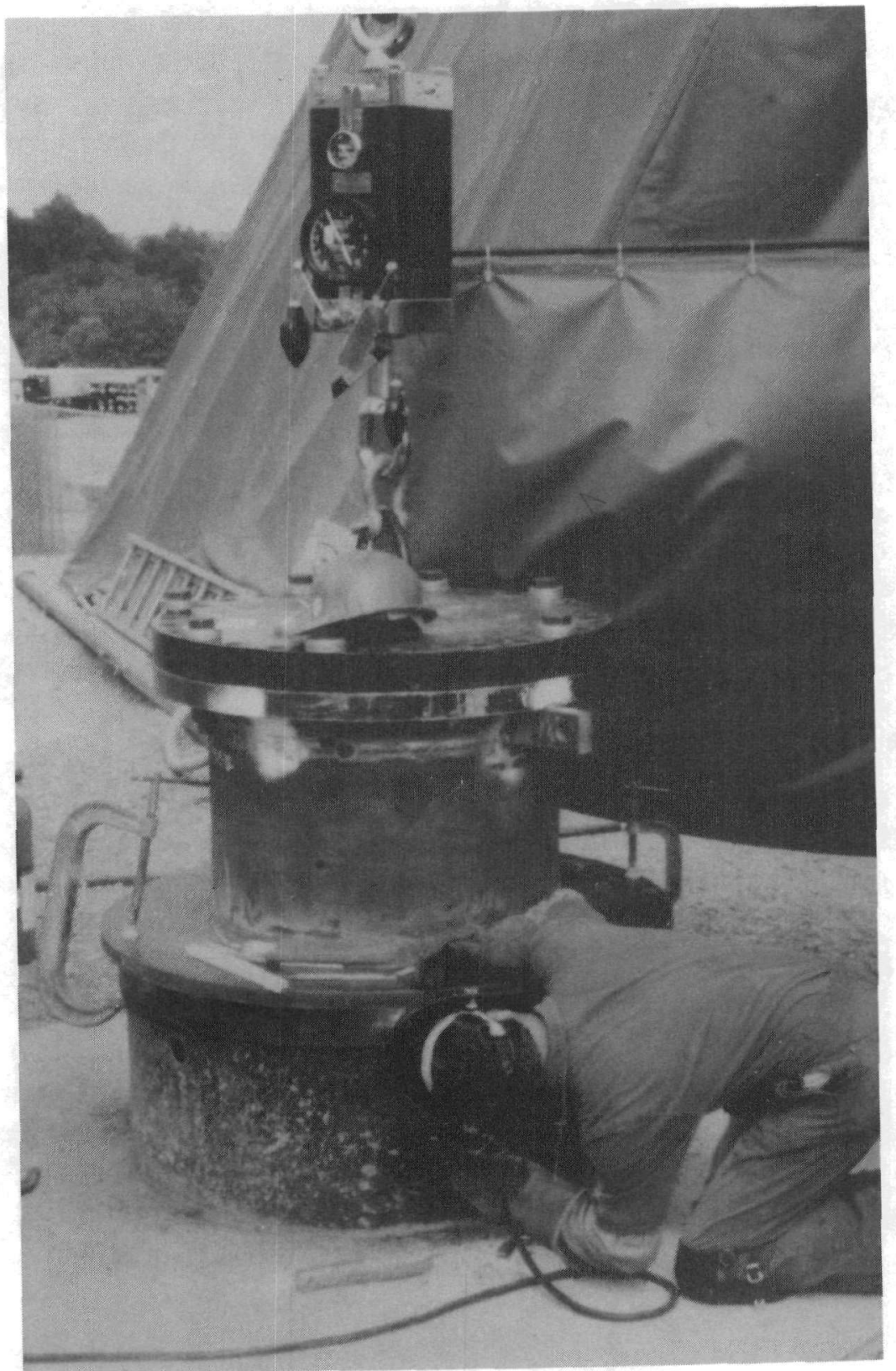

FIGURE 18

Final Riser Welding 


\subsection{SPECIAL TOOLING AND TECHNIQUES}

The technology base for Decontamination Operations has greatly expanded as a result of the work done by WVNS at the West Valley Demonstration Project. For the first time, the technology required for the decontamination of a commercial nuclear reprocessing facility for its subsequent re-use has been developed and successfully implemented.

Major accomplishments were made by decontamination engineers in adapting and modifying existing technologies for Decontamination Operations. This section will deal with the technology development in the areas of: (1) routine decontamination methods, (2) robotics and remote applications, (3) Ultra High-Pressure (UHP) water/abrasives and (4) size reduction/high-speed cutting ${ }^{[19]}$.

\subsection{ROUTINE METHODS}

Decontamination engineering and operations personnel worked closely with radiation and safety (R\&S) personnel to develop safe and efficient methods to approach and carry out Decontamination Operations. The following methods have become routine as a result of the experience gained at the WVDP.

\subsubsection{CELL CHARACTERIZATION}

In planning cleanup methods, it is important to know the general condition of a cell and the location of hot spots, as well as general radiation and contamination levels. A great deal of preplanning is required before decontamination operations begin due to the potential for extremely high radiation fields and contamination levels. The cells were characterized prior to cleanup using procedures and equipment developed to accomplish this safely. Characterization involved: (1) core drilling access penetrations into the cell; (2) videotaping the cell interior through the penetrations or on a remote manipulator arm in order to identify problems and plan work; (3) inserting radiation detectors, thermoluminescent dosimeters (TLDs) and temperature measurement devices to prepare detailed radiation surveys; and (4) obtaining solid, liquid and airborne samples for detailed analysis by using manipulator arms, a mobile robot, a telescoping vacuum device and/or manned entries.

\subsubsection{RADIATION WORKER SAFETY}

\section{Training}

All engineers, operators and supervisors are required to undergo radiation worker training. The training prepares personnel for understanding and dealing with:

- personnel protective clothing

- individual control of exposure

- radiation and contamination control 
- spill prevention and recovery

- emergency response

The contents of this training are listed in table $4^{[20]}$. In order for operators to progress from one skill level to a higher level, they must pass written and practical qualification examinations ${ }^{[21]}$.

Prior to most operations, workers are trained to use the necessary equipment using mock-ups or models. Ventilation is established and multicell contamination containment tents are erected at the point of entry to prevent the spread of contamination. 
Table 4: Radiation Worker Training Overview

1.0 Fundamental Radiation Theory

1.1 General

1.2 Atomic Structure

1.3 Interaction of Radiation with Matter

1.4 Measuring Radioactivity

2.0 Biological Effects of Radiation

2.1 General

2.2 External and Internal Radiation Dose

2.3 Relative Biological Risk

2.4 Effects of Radiation

2.5 Radiosensitivity

2.6 Radiation Exposure

2.7 Radiation Exposure and Permissible Dose

3.0 Prenatal Exposure

4.0 Methods to Control External Radiation Exposure

5.0 External Radiation Dosimetry

5.1 Personnel Dosimetry

5.2 TLD and Self-Reader

5.3 Facility Monitoring Systems

6.0 Contamination Control

6.1 General

6.2 Surface Contamination

6.3 Airborne Radioactivity

6.4 Contamination Control Techniques

6.5 Monitoring for Radioactive Contamination

6.6 Transfer of Radioactive/Contaminated Materials

7.0 Decontamination and Waste Minimization

7.1Decontamination

7.2 Waste Reduction

8.0 Controlled Area Posting

9.0 Radiological Incidents

10.0 Individual Responsibilities

11.0 Employer (WVNS) Responsibilities 
Clothing

Anticontamination (Anti-C) clothing and respiratory protection are worn to insure the health and safety of Decontamination Operators working in contaminated areas. Standard procedures are established for donning Anti-C clothing to prevent operator and clean area contamination. The Anti-Cs required for a typical PPC manned entry were:

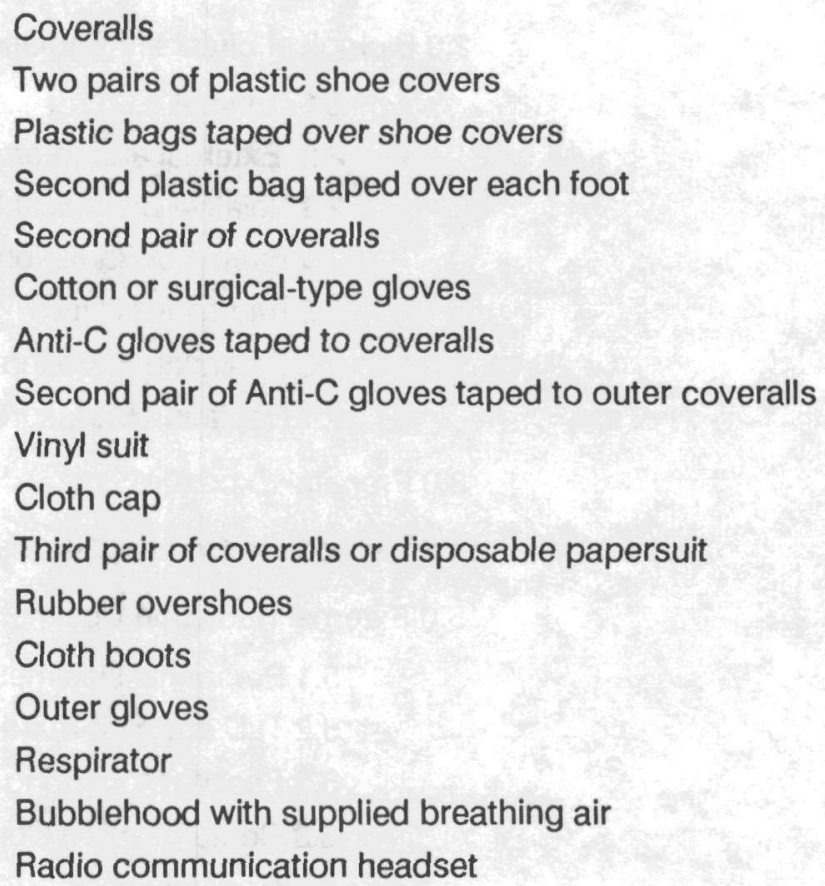

The average time for suiting up is approximately one hour, while about 20 minutes is required for suiting down. Figure 19 shows an operator suiting up for a cell entry.

Each person working in-cell was supported by a backup person whose job was to monitor the in-cell operator. The clothing needed and high temperatures in the cells usually limited a team's entry to 2 hours.

Proper training, safe work procedures, proper protective equipment and backup systems all contributed to safe and successful manned entries.

\subsubsection{IN-CELL SAFETY PROCEDURES}

Safety measures taken during in-cell manned entries included: (1) sampling and analysing debris; (2) removing trash, old tools, hoses etc.; (3) vacuuming floor debris; (4) mixing debris with cement or isolating small quantities to insure safe removal; (5) ultrasonic telltaling of pipes and vessels to determine the presence or absence of liquids; and (6) mechanical telltaling if liquids were present and required draining. Figure 20 shows the mechanical telltale device. 


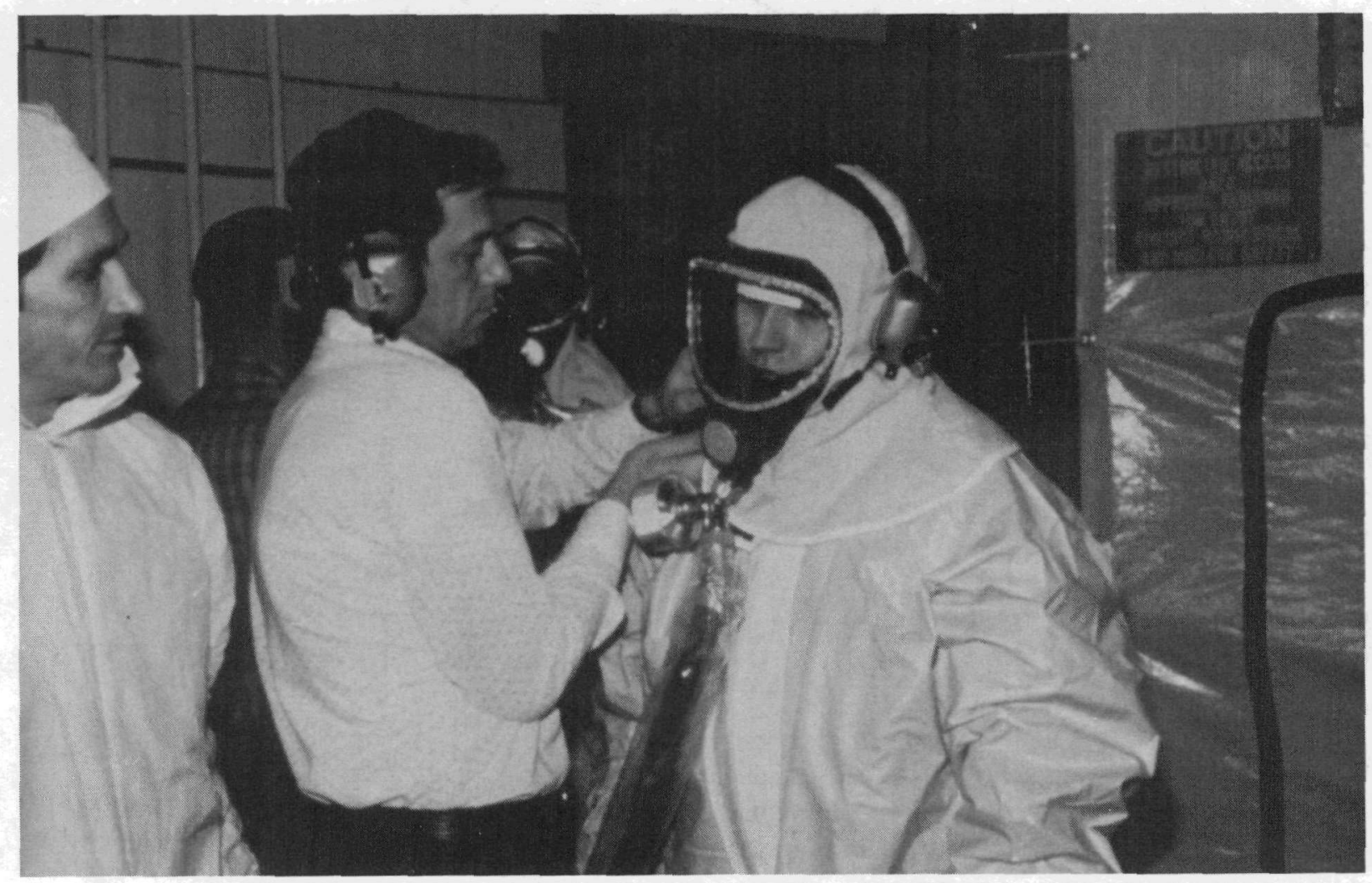

FIGURE 19

Sulting Up for Gell Entry 


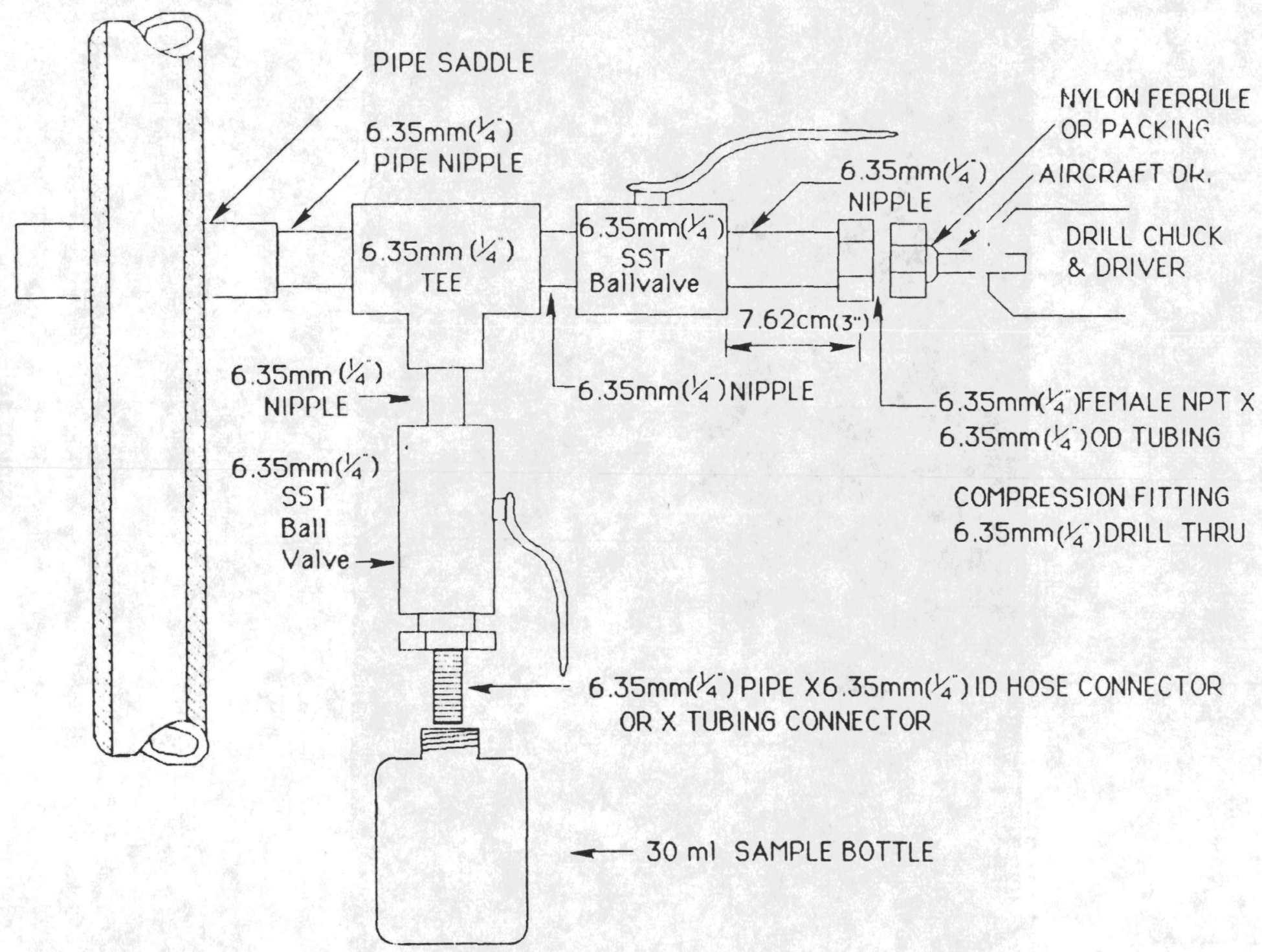

FIQURE 20

Device for Removing Liquid Samples (Telitale) from Pipes 


\subsubsection{CONTAMINATION CONTROL}

Contamination control was accomplished by: (1) spraying colored fixatives on pipes and vessels; (2) injecting expandable polyurethane foam into contaminated pipes prior to cutting; (3) heat-shrink capping of cut pipe ends; (4) using Anti-C clothing, containment tents and establishing ventilation; and (5) following specific waste handling procedures. Figure 21 shows a cut pipe that was foamed.

\subsubsection{IN-CELL SURFACE DECONTAMINATION METHODS}

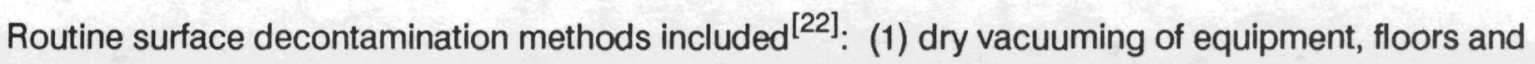
walls; (2) misting and spraying with water; (3) applying foam and rinsing; (4) wipedown with water or detergent-dampened cloths in contact decon cells; (5) high-pressure water or chemical spraying of equipment, structures and inner-cell surfaces; (6) removing equipment; and (7) floor and wall scabbling or grinding as shown in figure 22.

\subsubsection{WASTE PACKAGING}

Wastes generated from the Decontamination Operations required proper packaging, removal and temporary storage. Wastes were packed into $0.2-\mathrm{m}^{3}$-capacity $\left(7.5 \mathrm{ft}^{3}\right)$ drums, $1.8-\mathrm{m}$ by $1.8-\mathrm{m}$ by $3.6-\mathrm{m}$ boxes $(6 \mathrm{ft}$ by $6 \mathrm{ft}$ by $12 \mathrm{ft}), 2.5-\mathrm{m}^{3}$ boxes $\left(88 \mathrm{ft}^{3}\right)$ and boxes as large as $3.4 \mathrm{~m}$ by $3.4 \mathrm{~m}$ by $6.1 \mathrm{~m}(4 \mathrm{ft}$ by $11 \mathrm{ft}$ by $20 \mathrm{ft}$ ). Waste packages may have poly-liners, outer wrappings and are sometimes packed into larger containers to insure the contamination is contained.

In the CPC, waste from the cell was remotely loaded into prewrapped metal boxes and transferred to the EDR where the outer wrapping was removed. The original box was then loaded into a second prewrapped outer transfer box which was then sealed. That box was then surveyed remotely, transferred and its outer wrapping was then removed. Figure 23 shows a unique waste storage facility designed for interim storage of the waste generated in the decontamination of the CPC. It is a sprung structure with shielding provided by low-level waste solidified in concrete shielding modules.

\subsection{ROBOTICS AND REMOTE APPLICATIONS}

High radiation and contamination levels limited or prohibited manned entries for the cleanup of certain areas. Creative WVNS personnel successfully met the challenge to decontaminate such areas using remote equipment.

Some of the most significant technological developments have occurred in adapting existing technologies for remote Decontamination Operations. Remote technologies used at the WVDP include:

(1) Robotics, (2) Electromechanical Manipulators, (3) Hydraulic Manipulators, (4) Master Slave Manipulators (MSM), (5) Cranes, (6) Long-handled Gripping Tools, (7) A complete pipe cutting and collection system, (8) An ultra high-pressure water and abrasive device for cutting and cleaning and (9) Hydraulic tools. 


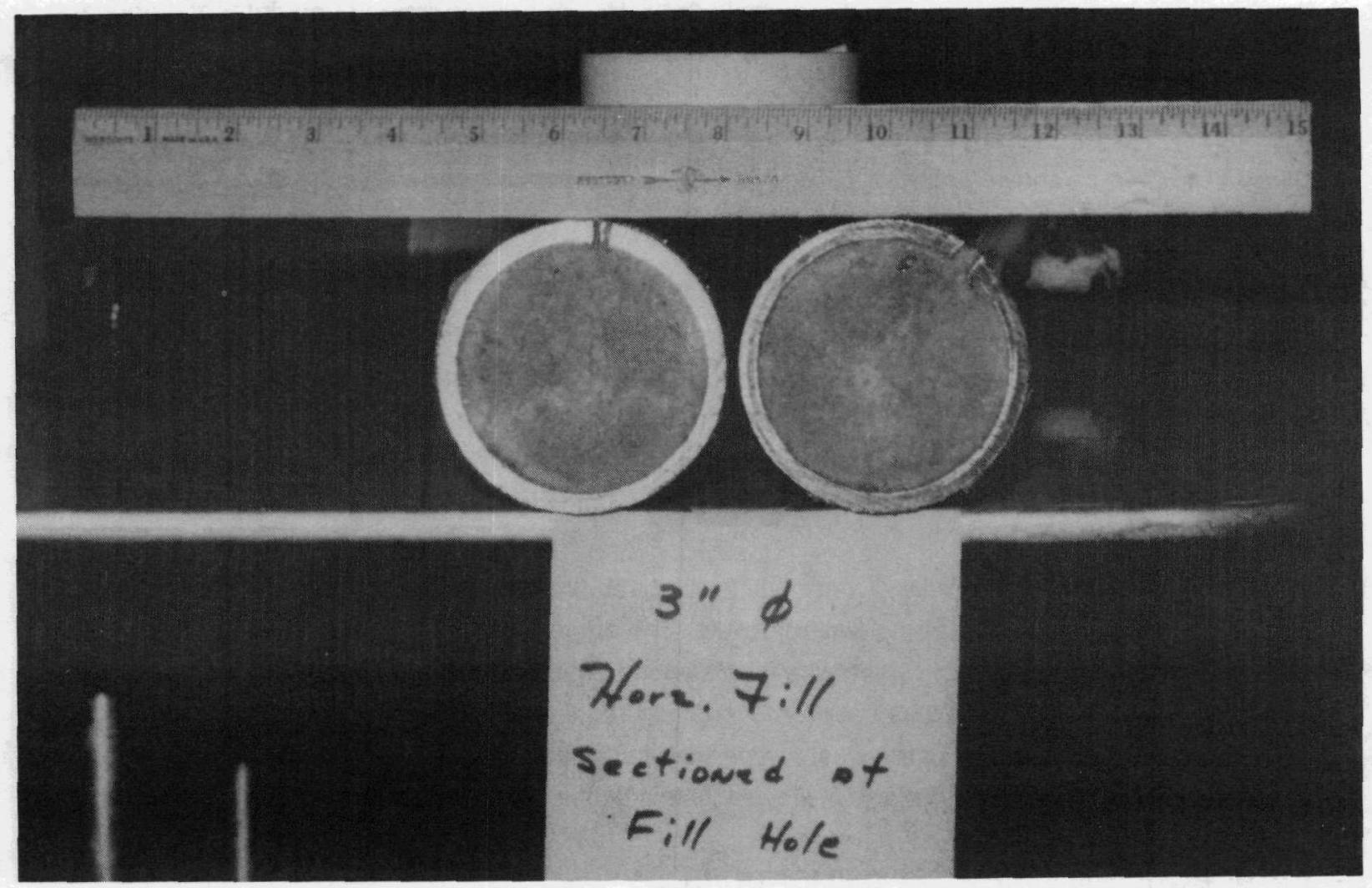

FIGURE 21

Fixing Contamination in Pipes Prior to Gutting. the Interior Is Filled with Polyurethane Foam 


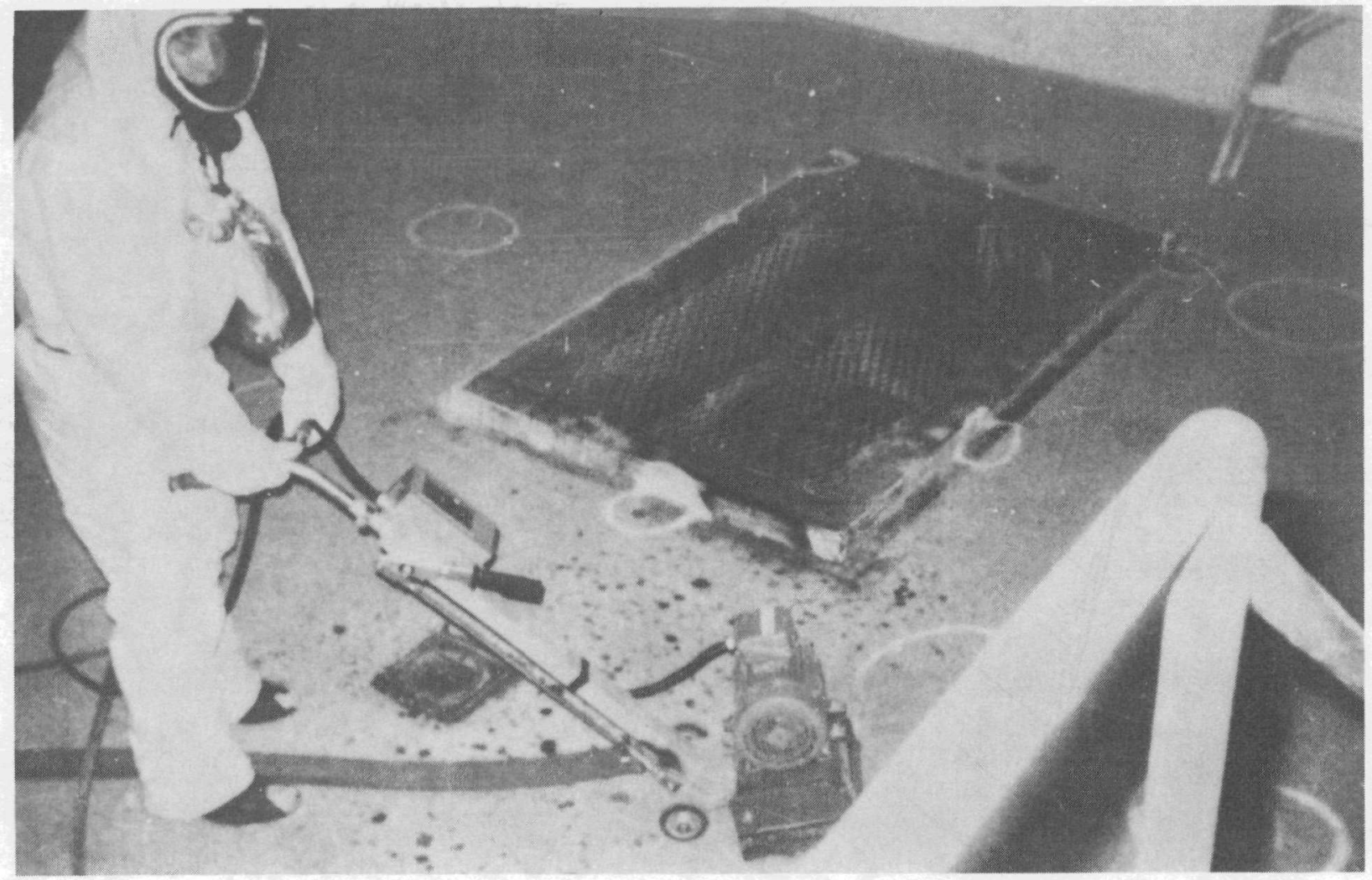

FIGURE 22

Surface Cleaning Tool Used for Cell Decontamination 


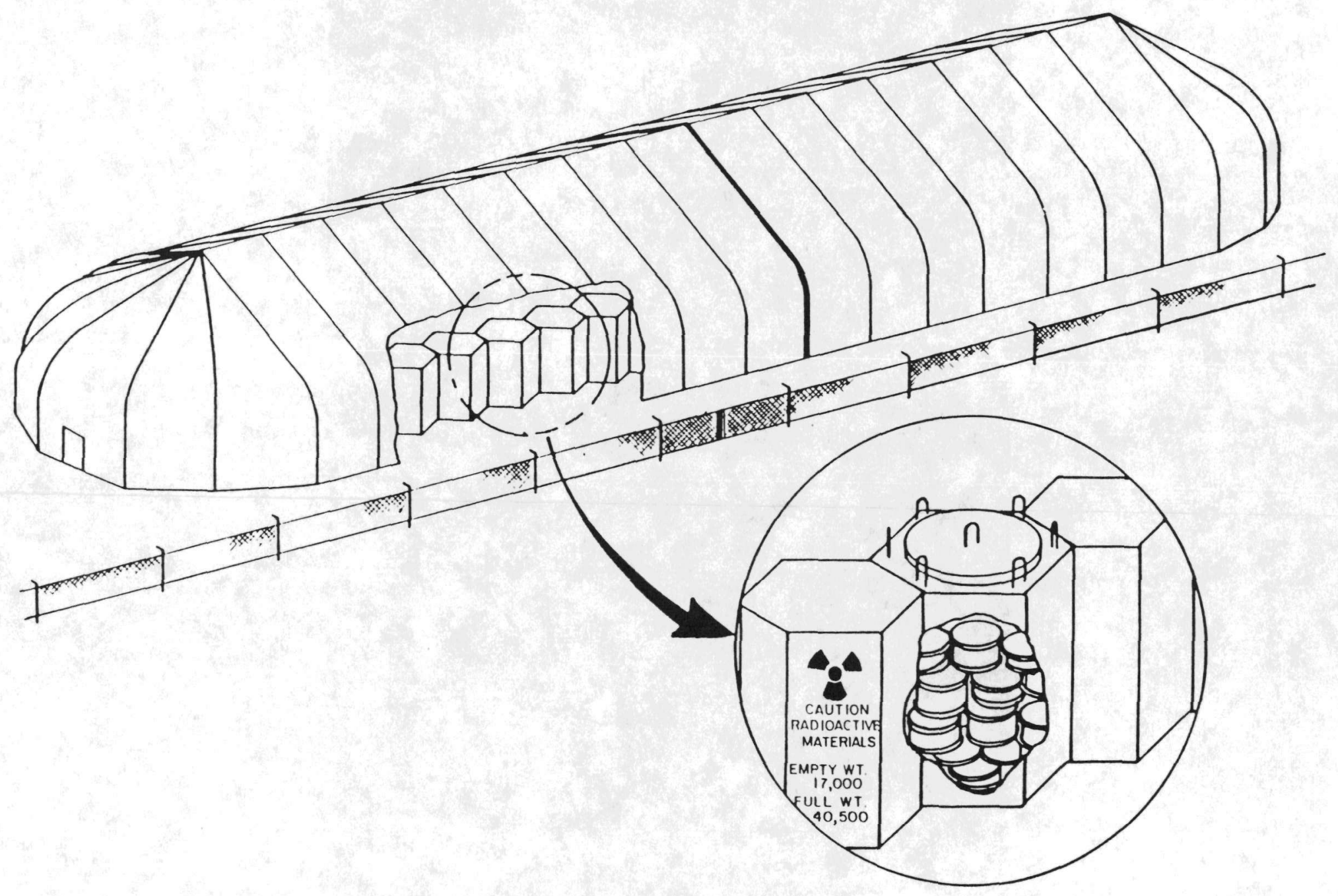

FIGURE 23

Storage Facllity Used to Gontain and Shield

Boxed Vessels Removed from the GPC 
$\underline{\text { Robotics }}$

A 6-wheel mobile robot was used to remotely sample the CPC and vacuum cell surfaces. The robot was a learning machine that could be rogrammed for specific motions to accomplish light-duty decontamination tasks. Figure 24 shows the robot.

\section{Manipulators}

Remote decontamination would not be possible without the use of manipulators. They are strong and versatile mechanical arm-like devices that were made to do a variety of remote decontamination tasks such as: (1) operating an impact wrench to remove Hanford-type quick connectors, (2) removing jumpers, (3) cutting pipe with modified abrasive cut-off saws and hydraulic pipe shears, (4) packaging and removing pipes, (5) controlling Ultra High Pressure (UHP) water/abrasive cleaning and scarifying tools, (6) placing UHP water/abrasive cutting and tracking systems in place to cut CPC concrete pedestals, (7) vacuuming walls and floor to remove contamination and clean debris, (8) videotaping of cell, (9) radiological probe surveying, (10) smear sampling device and (11) installing drum closure rings on waste packages.

\section{Cranes}

Cranes are another extremely important machine that enable a variety of decontamination tasks to be accomplished. Cranes were used to: (1) remove a variety of wastes and waste packages from contaminated areas and (2) operate remote devices such as a concrete sampling device, a drum lifting device and the CPC pedestal tipping fixture. Many bridge and jib cranes of various capacities were used throughout the facility.

\subsection{HIGH-PRESSURE WATER ABRASIVES}

A commercially available Ultra High-Pressure (UHP) water cutting and cleaning system was used at the WVDP to accomplish many challenging tasks. UHP equipment has been used commercially to do such tasks as cleaning ship hulls and brick buildings and for cutting metals, concrete and rock.

The UHP system can expel water through an orifice, up to $241 \mathrm{MPa}(35,000 \mathrm{psi})$ to form a high-energy jet stream. The water stream can be used to clean hard materials (concrete, steel etc.) or to cut softer materials (plastic, wood etc.). Garnet grit can be added to the water stream for wet grit blasting or for cutting hard materials. The key components of the UHP System are:

1. Diesel-Powered Water Pressurizing Unit - Uses oil intensifiers (piston type pumps) to increase water pressure to a maximum of $241 \mathrm{MPa}(35,000 \mathrm{psi})$.

2. Abrasive Water-Jet Nozzle System - Combines garnet grit with the water stream to produce a high-energy narrow stream of water and abrasive (figure 25). 


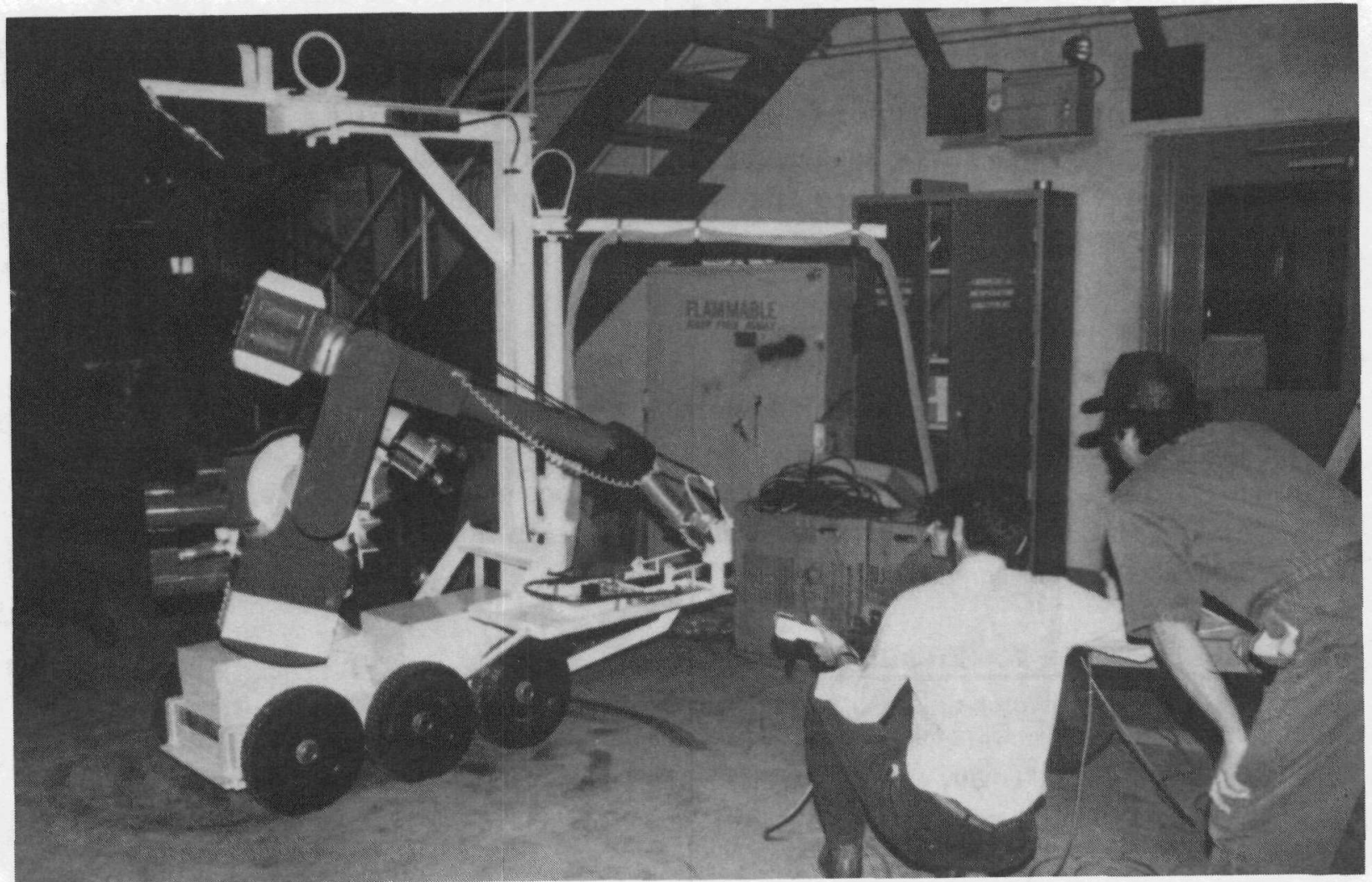

FIGURE 24

Preprogramming a Robot tor GPC sampling and Cleanup of Debris 


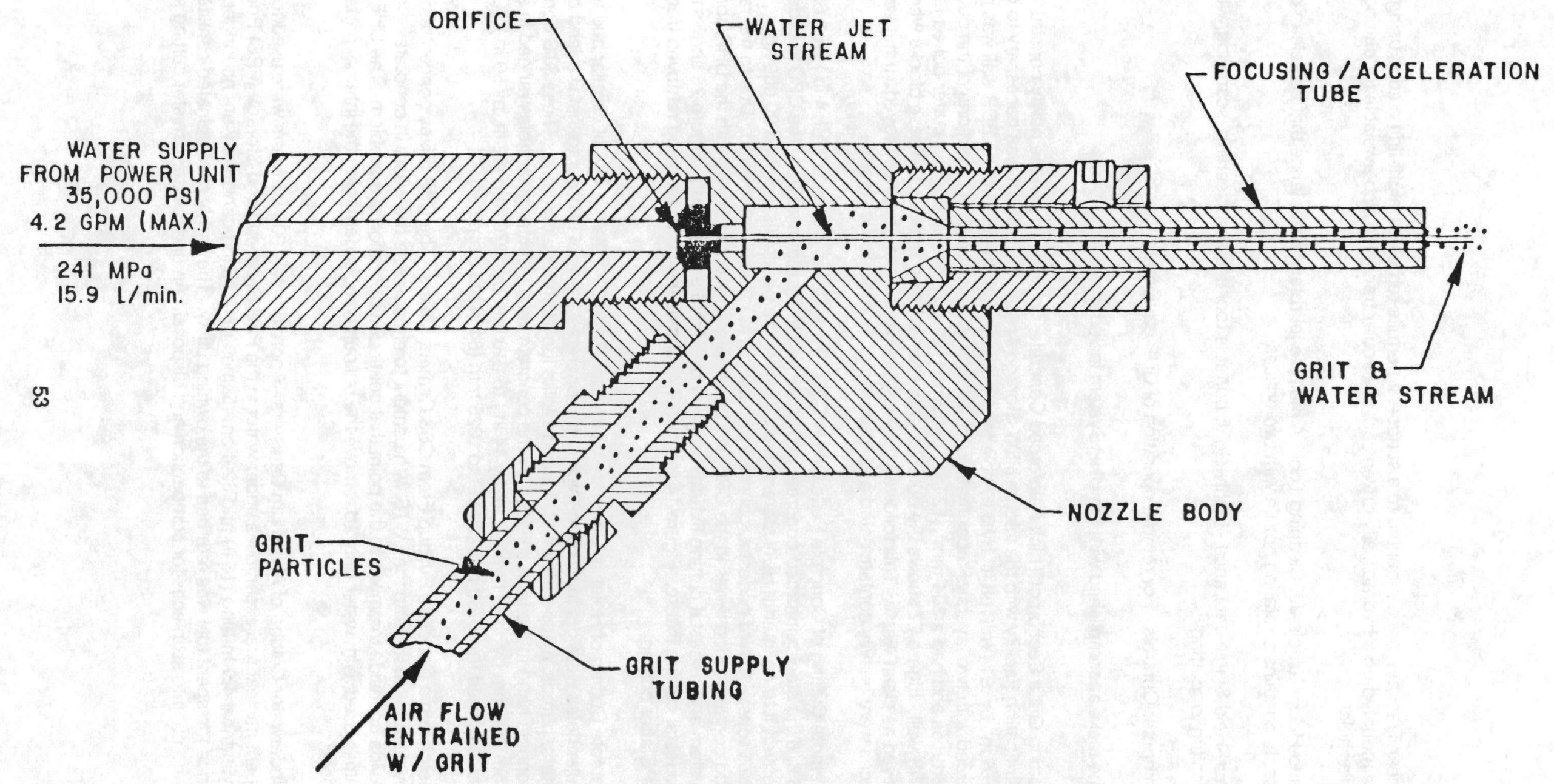

FIGURE 25

Abrasive Jet Nozzle Assembly 
3. Linear Tracker - Once mounted to a surface, it permits remote straight-line cutting using a nozzle mounted on a hydraulically driven cart. A circular tracker is also available for cutting circular holes.

4. Hand-Held, Multiple-Jet Cleaning Tool - A multiple-jet rotary water lance that can clean or scarify contains a rotating nozzle with two orifices.

5. Hand-Held Single-Jet Lance - Lightweight, portable tool used for cleaning, scarifying, wet grit blasting, or cutting.

6. Computer Controls - For remote operation of UHP equipment.

Some of the tasks accomplished with the UHP System include:

1. Cutting Out a Section of Thick Reinforced Concrete - in order to join the newly constructed Vitrification Facility with the interim HLW Storage Area in the plant, it was necessary to cut a $15.6 \mathrm{~m}^{2}$ by $.914 \mathrm{~m}\left(168 \mathrm{ft}^{2}\right.$ by $3 \mathrm{ft}$ ) hole for a path through the EDR. The EDR wall was reinforced with two layers of rebar mat. Each layer was $50.8 \mathrm{~mm}$ (2 in.) from one of the outer wall surfaces and had a $304-\mathrm{mm}^{2}\left(12 \mathrm{in}^{2}{ }^{2}\right)$ pattern. Figure 26 shows the kerf cutter bolted to the EDR wall. Figure 27 shows the outer layer of blocks being removed. These blocks were surveyed as clean waste. This followed the waste minimizing strategy employed. Inner wall surfaces were heavily contaminated and disposed of as radioactive waste.

2. Remote Cutting of Concrete Pedestals in CPC - Two 2.24-m-diameter ( $7 \mathrm{ft}, 4 \mathrm{in}$.) by 2.65 - $\mathrm{m}$-tall ( $8 \mathrm{ft}, 8 \mathrm{in}$.) steel-reinforced concrete pedestals had to be removed from the CPC in order to convert it to an interim HLW storage area. Two of the pedestals weighed $20,000 \mathrm{~kg}$ (22.5 tons). A third pedestal, only 460 - $\mathrm{mm}$-tall ( $18 \mathrm{in}$.) was also removed. Due to the radiation and contamination levels in the CPC, the pedestals were cut remotely with the UHP/abrasive system and pedestal cutting fixture designed by WVNS engineering. Figure 28 shows the pedestal cutting fixture. Figure 14 (section 7.4 ) shows the pedestal being removed from the $\mathrm{CPC}$ after cutting.

3. Remote Cutting of Holes in Concrete Vault Roof (Tank 8D-1) - A variety of circular and rectangular holes were cut into 0.6 - $\mathrm{m}$-thick $(2 \mathrm{ft}$ ) concrete vault roof in order to install a feed column, filters, pumps, a supernatant chiller and zeolite ion-exchange columns. These STS components hang in the tank shielded by the concrete vault. Rectangular holes ranged in size from $660 \mathrm{~mm}$ by $1120 \mathrm{~mm}$ ( $26 \mathrm{in}$. by $44 \mathrm{in}$.) to $810 \mathrm{~mm}$ by $1270 \mathrm{~mm}$ (32 in. by $50 \mathrm{in}$.). Circular holes ranged from $760 \mathrm{~mm}$ ( $30 \mathrm{in}$.) to $1625 \mathrm{~mm}$ (64 in.) in diameter.

4. Removing a Concrete Buildup From CSS Cement Mixers - The CSS mixes concentrated lowlevel liquid waste from the LWTS with cement to encapsulate the waste in concrete. Concrete builds up inside the mixer to the point that continued operation is a problem. The UHP system is used, with water only, to remove the buildup without damaging the internal parts of the mixer.

5. Underwater Cutting of Aluminum Canisters - Approximately 900 canisters were used to store spent nuclear fuel assemblies under water in the Fuel Receiving and Storage (FRS) Pool. The cylindrical 4.9-m-long (16 ft) and 32.4-cm-diameter (12.75 in.) canisters were no longer useful once the spent fuel was returned to the owning utility. The highly contaminated canisters were cut into six pieces for compaction and disposal. An underwater canister cutting system 


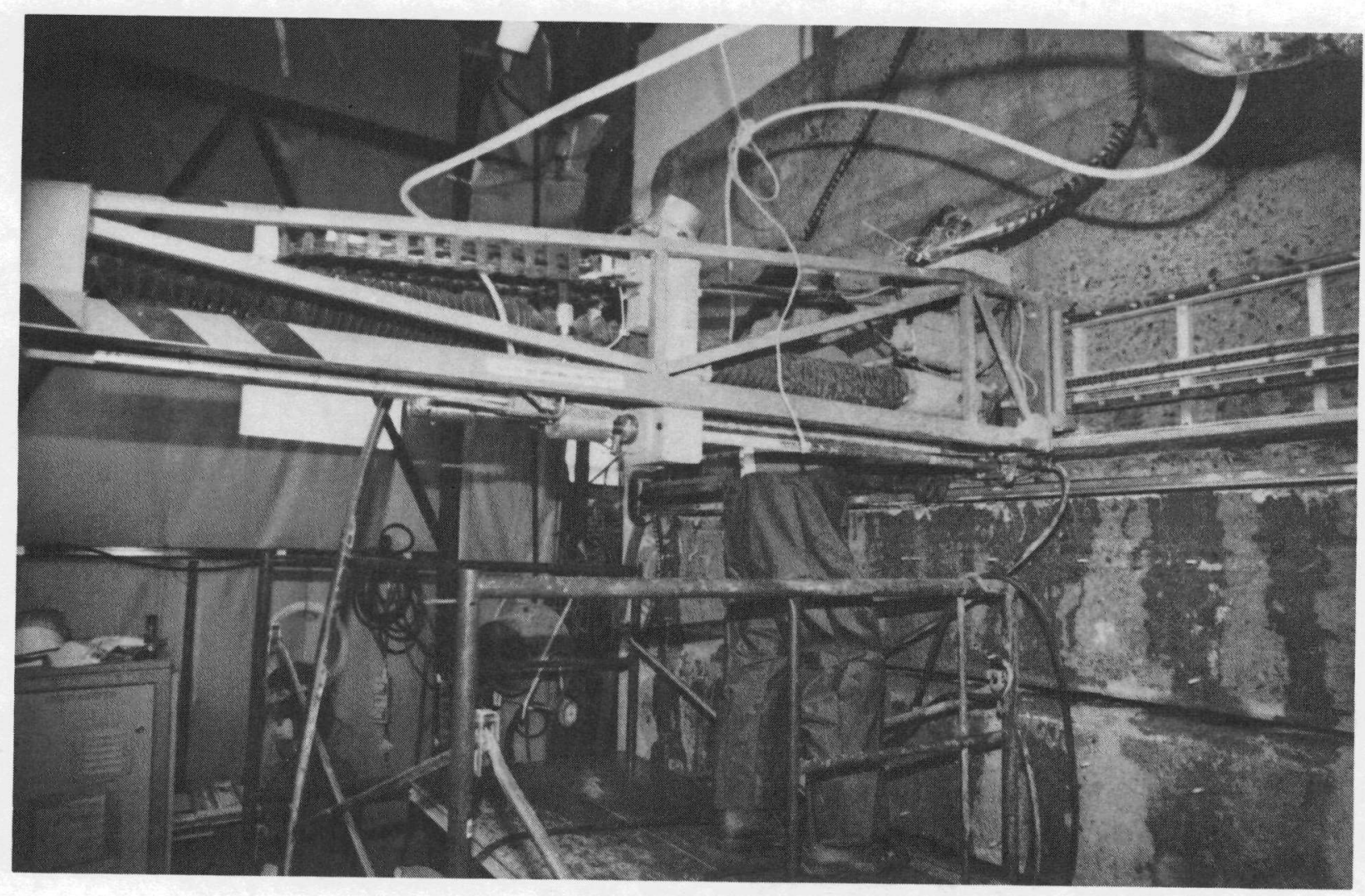

FIGURE 26

Cutting Arrangement for Opening a Passage

from the Vitrification Faclitty to the HLW storage Area (EDR) 


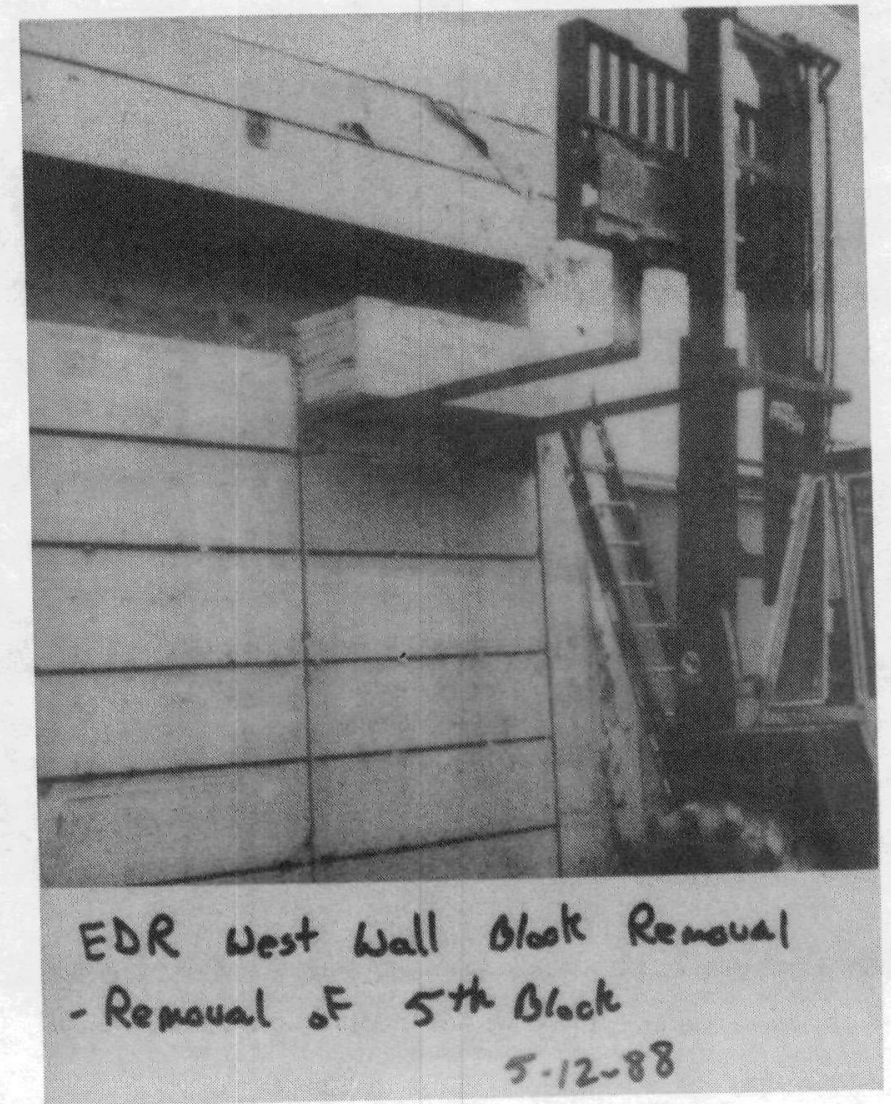

FIGURE 27

Removal of EDR Outer Layer of Blocks

After High-Pressure Water/Abrasive Gutting 


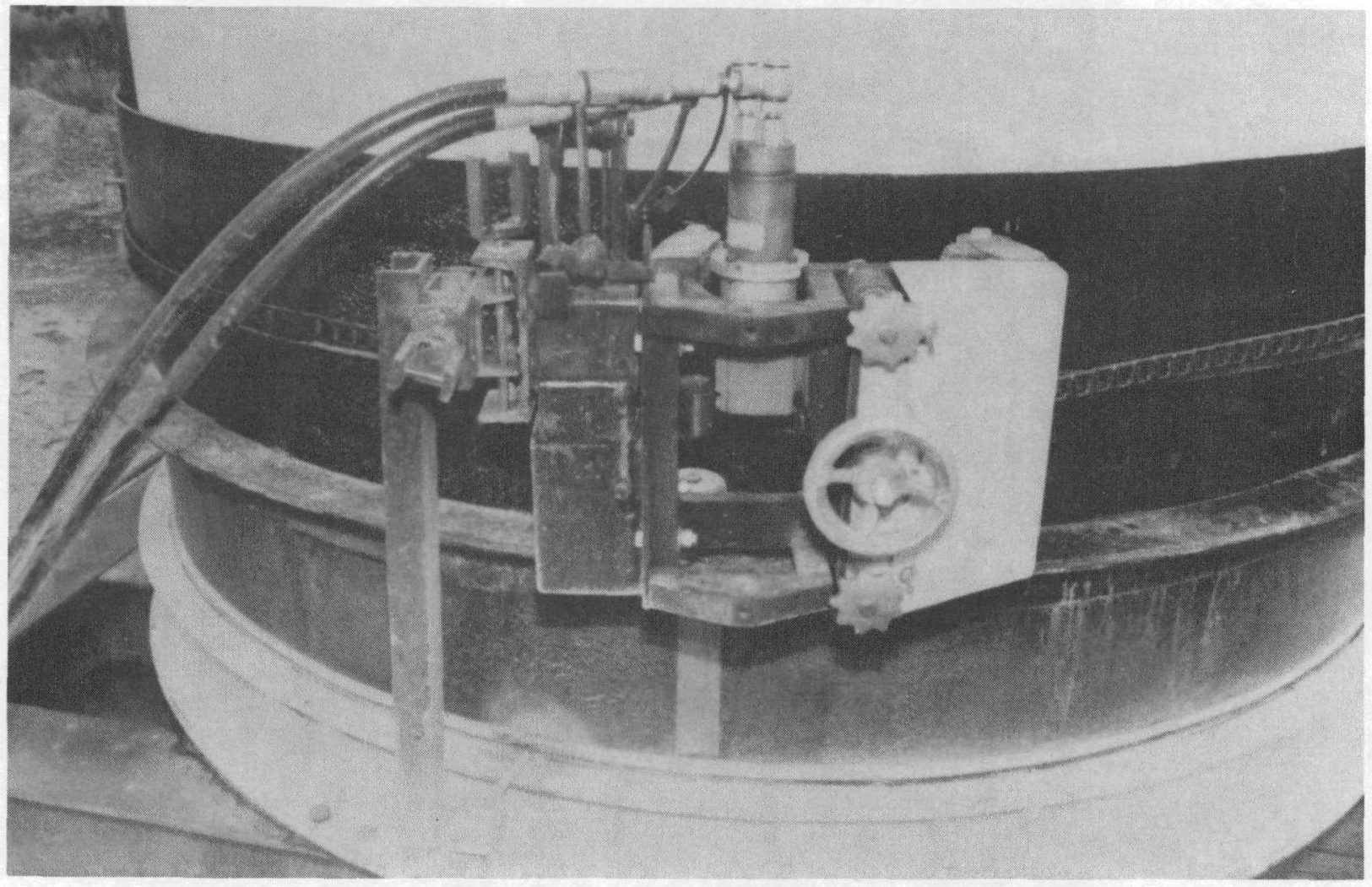

FIGURE 28

Setup for Pedestal Gutting 


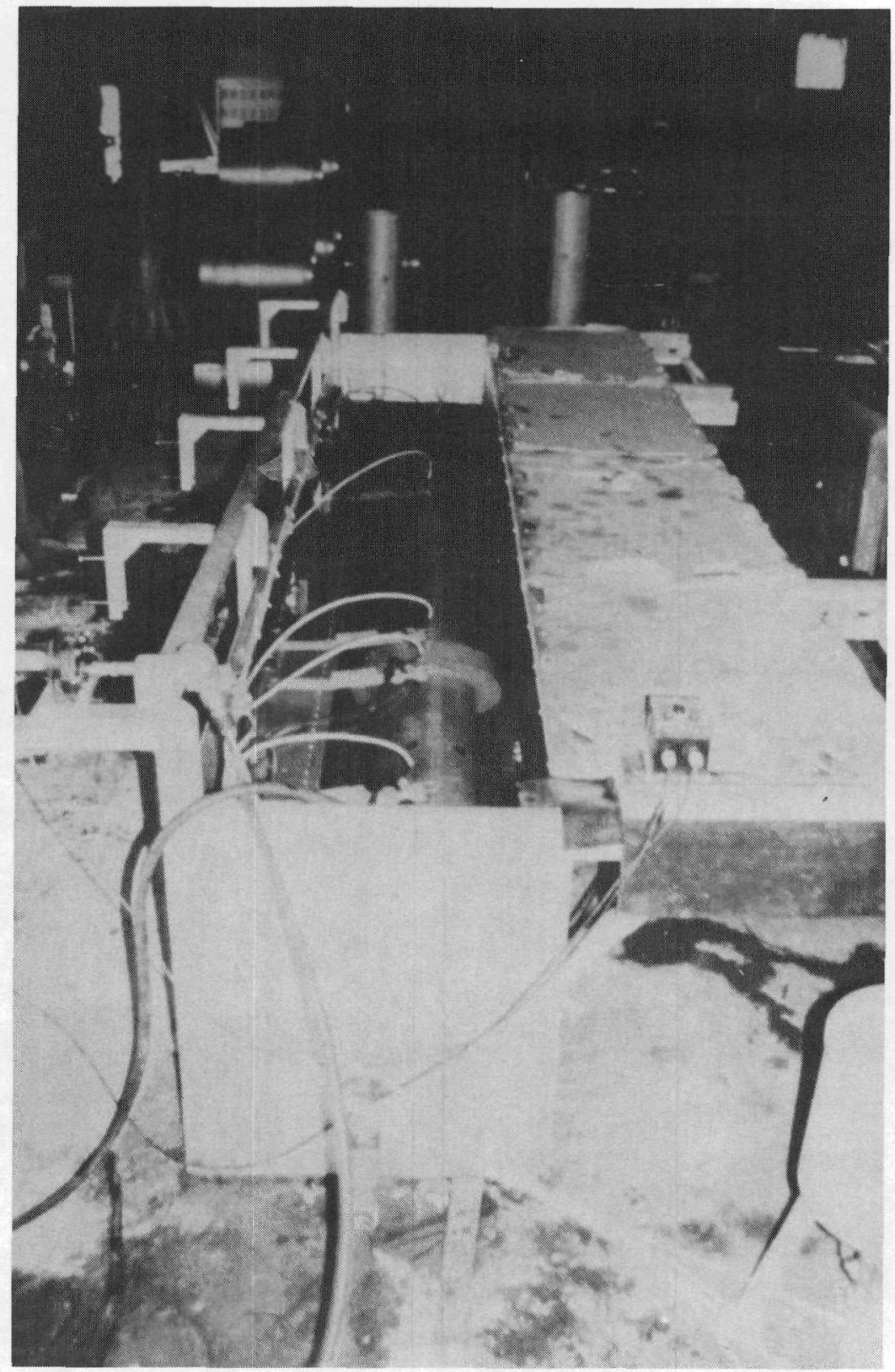

FIGURE 29

Underwater Sectloning of Canisters

Used to Store Spent Fuel 
was designed by WVNS that used the UHP system (water and abrasives) to make the five cuts on each canister simultaneously. Figure 29 shows the canister cutting device.

6. Decontaminating Interior Surfaces of Cells - Cell ceilings, walls and floors have had varying amounts of smearable and fixed contamination on their surfaces. In order to remove this contamination, WVNS has successfully utilized many techniques, one of which employs a UHP water spray. This has been accomplished both remotely and by in-cell operators. This technique has been especially successful in removing contaminated paint.

7. Removing a Concrete Knee Brace - In the construction of the Vitrification Facility (VF), it was necessary to join a new pipe chase from the VF to another outside the CSS building. At the location where the two would be joined, there existed a 61 -cm-thick $(24 \mathrm{in}$.), $2948 \mathrm{~kg}(6,500$ ton) concrete reinforced brace. The brace was reinforced with $19.0-\mathrm{mm}(3 / 4 \mathrm{in}$.) and $28.6-\mathrm{mm}$ diameter (1-1/8 in.) rebar. The UHP system was used to make cuts necessary to remove the brace.

8. Cutting a Hole for Pipe Chase Installation - To support the installation of a pipe chase for process lines to the CSS, a hole $61 \mathrm{~cm}$ by $107 \mathrm{~cm}$ ( $2 \mathrm{ft}$ by $3.5 \mathrm{ft}$ ) was required in a UWA wall (in the Process Building). The wall was $30.5-\mathrm{cm}$-thick (12 in.) concrete reinforced with a 12.7$\mathrm{mm}$-diameter (.5 in.) rebar. The inside area of the UWA was a contamination control area. A carbon-steel deflector/collector system was developed and fabricated that controlled the water, grit and cuttings to avoid spreading contamination and damaging nearby structures.

9. Enlarging a Concrete Valve Niche - A $30.5-\mathrm{cm}$-thick (912 in.) high-density concrete wall lined with $9.5-\mathrm{mm}$-thick ( $3 / 8 \mathrm{in}$.) stainless steel was removed to enlarge a valve niche to accommodate a new LWTS pump.

10. Sectioning the Borosilicate Glass Logs - Samples have been obtained from test (nonradioactive) logs as part of waste form qualification work.

It is important to note that the high energy of the UHP system, when used with abrasives, can damage structures behind the concrete unless special precautions are taken.

The system was in most cases faster, less expensive and less destructive to nearby structures than conventional methods such as a jack hammer or explosives ${ }^{[23]}$.

\subsection{SIZE REDUCTION}

The objective of size reduction at WVNS is to reduce the volume of waste generated from Decontamination Operations resulting in reduced storage and disposal costs.

Size reduction may be accomplished in cell during Decontamination Operations or in other facilities WVNS has designed specifically for this purpose. Two facilities for waste volume reduction have been installed and used at WVNS: a Contact Size Reduction Facility (CSRF) for handling materials with an exposure rate less than $100 \mathrm{mr} / \mathrm{hr}$ and a 1000-ton supercompactor for reducing the volume of 208-liter (55-gallon) drums. 
Whether the size reduction takes place in cell or in one of the special facilities, the tools and techniques are generally common. Some of the tools/machines used to reduce the volume of waste are:

1. Abrasive Saws - Commercially available portable abrasive cutoff saws were used in cell by operators and were modified to be used remotely with the manipulators. A large 510-mmdiameter (20 in.) high-speed abrasive cutting saw was designed, constructed and utilized to cut remotely when suspended from a crane. It is capable of cutting $50-\mathrm{mm}(2 \mathrm{in}$.) schedule 80 stainless-steel pipe in 20 to 30 seconds and $150-\mathrm{mm}$ (6 in.) schedule - 80 pipe in about 2$1 / 2$ minutes. Figure 30 shows the large abrasive saw, while figure 31 shows a smaller portable saw, being operated by a manipulator in the CPC.

2. Plasma-arc Torches - Plasma-arc cutting has been successfully used both in cell and out. Dense fumes were generated using air-arc equipment. A Hi-Vac (vacuum) system was adapted to draw off the fumes and electrostatic precipitators were employed to clean the air where the cutting was taking place. The speed of plasma-arc torch cutting makes it an extremely useful tool when cutting radioactive material since this results in reduced operator exposure. Figure 32 shows the cutting of a vessel with the plasma torch.

3. Other equipment used in size reduction includes: (1) portable band saws, (2) reciprocating hack saws, (3) hydraulic pipe shears, (4) walk-around mill cutters, (5) nibblers, (6) UHP water and abrasive cutting systems and (7) a remote pipe cutting and collection system designed by WVNS.

To date, 27 vessels have been volume reduced in the CSRF using the above techniques. One tank with a volume of $28.1 \mathrm{~m}^{3}\left(993 \mathrm{ft}^{3}\right)$ was reduced to fit into a disposal box with a volume of $2.5 \mathrm{~m}^{3}\left(88 \mathrm{ft}^{3}\right)$. This represents a volume reduction factor of $11^{[24]}$.

4. A supercompactor, supplied by Westinghouse-Hittman, was employed to reduce 208-liter (55gallon) drums of low-level waste to less than a third of their original volume. The automatic hydraulic compactor has a ram that can generate a force of up to $8.9 \mathrm{mN}(1,000$ tons). The benefit of the supercompactor is that it can compress equipment normally considered noncompressible (such as piping, small valves, etc.). After the drums of waste are reduced, they are placed in large steel waste boxes. Compressing the waste reduces disposal cost by reducing volume and produces a denser, more stable waste form. The supercompactor in operation is shown in figure 33. Forty-four steel drums (208 liters), when compacted, fit into one $2.5-\mathrm{m}^{3}\left(88 \mathrm{ft}^{3}\right)$ disposal box as shown in figure 34 . To date, approximately 2500 drums have been compacted and loaded into 56 steel boxes for a volume reduction of 7:1. Disposal of drums is usually performed in a "6 pack," where 6 drums are banded together; one 6 pack is equivalent to the volume of one disposal box. In this disposal mode, 2500 drums would occupy the volume of 417 boxes, whereas supercompacting reduces the volume to 56 boxes. A cost savings, in containers alone, of $\$ 217$ thousand results using supercompactor. In addition, a waste volume savings of 917 cubic meters $\left(32,383 \mathrm{ft}^{3}\right)$ was realized.

5. Most of the waste generated during clean up was of an easily compressed nature such as plastic gloves, bags and anti-C clothing, as well as paper and other cleaning materials. This compressible waste was segregated at the waste generating location in plastic lined $208 \mathrm{~L}$ (55-gallon) drums. A box-compactor was used to compress this waste into $2.5 \mathrm{~m}^{3}\left(88 \mathrm{ft}^{3}\right)$ steel boxes. The compactor operates at $445 \mathrm{kN}$ (50 tons) and compresses the contents of 60 drums into one box thus achieving a volume reduction of 10:1. 


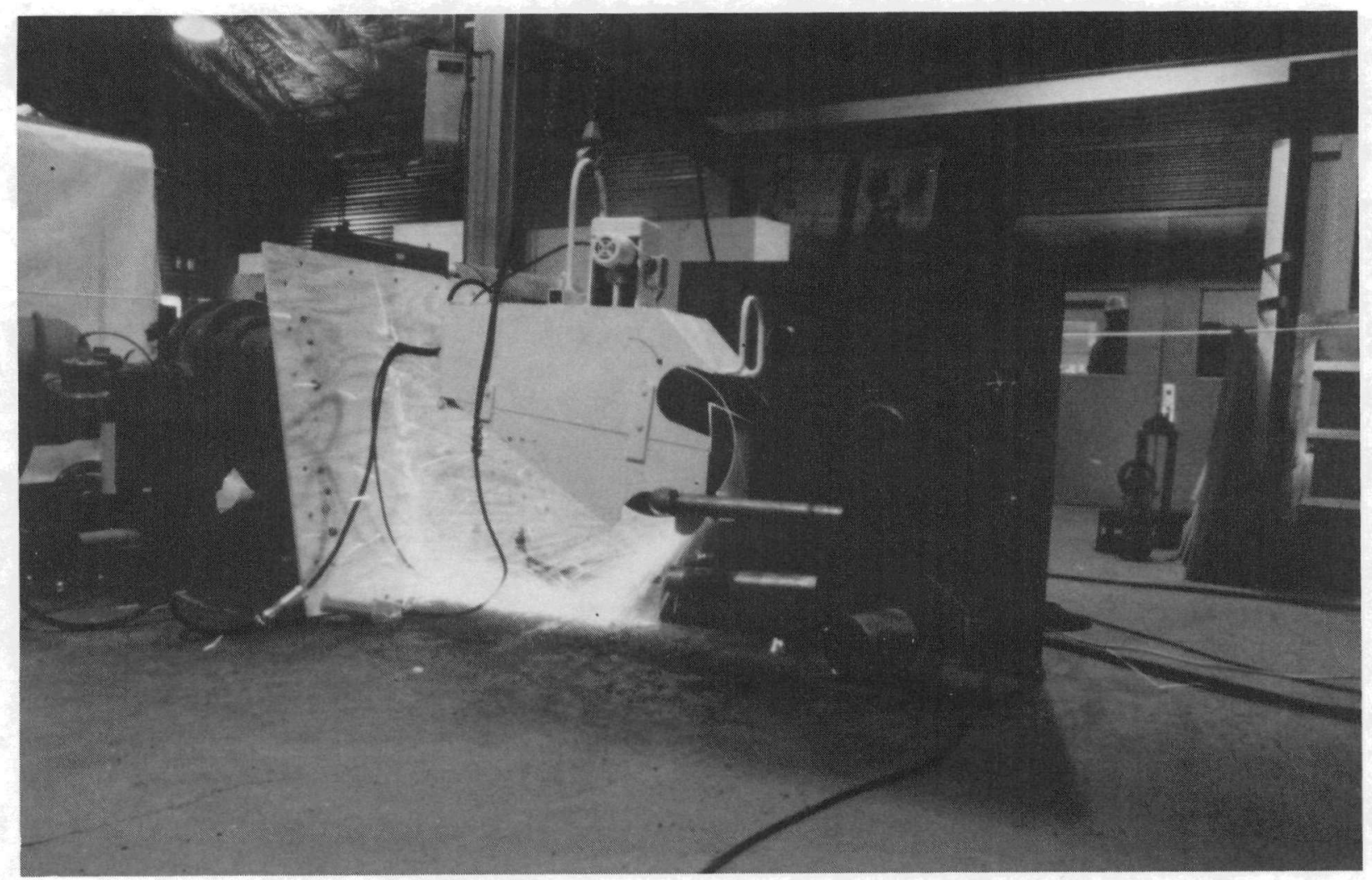

FIQUAE 30

Ahrasive saw Designed by Wris tor Remote Volume Reduction 


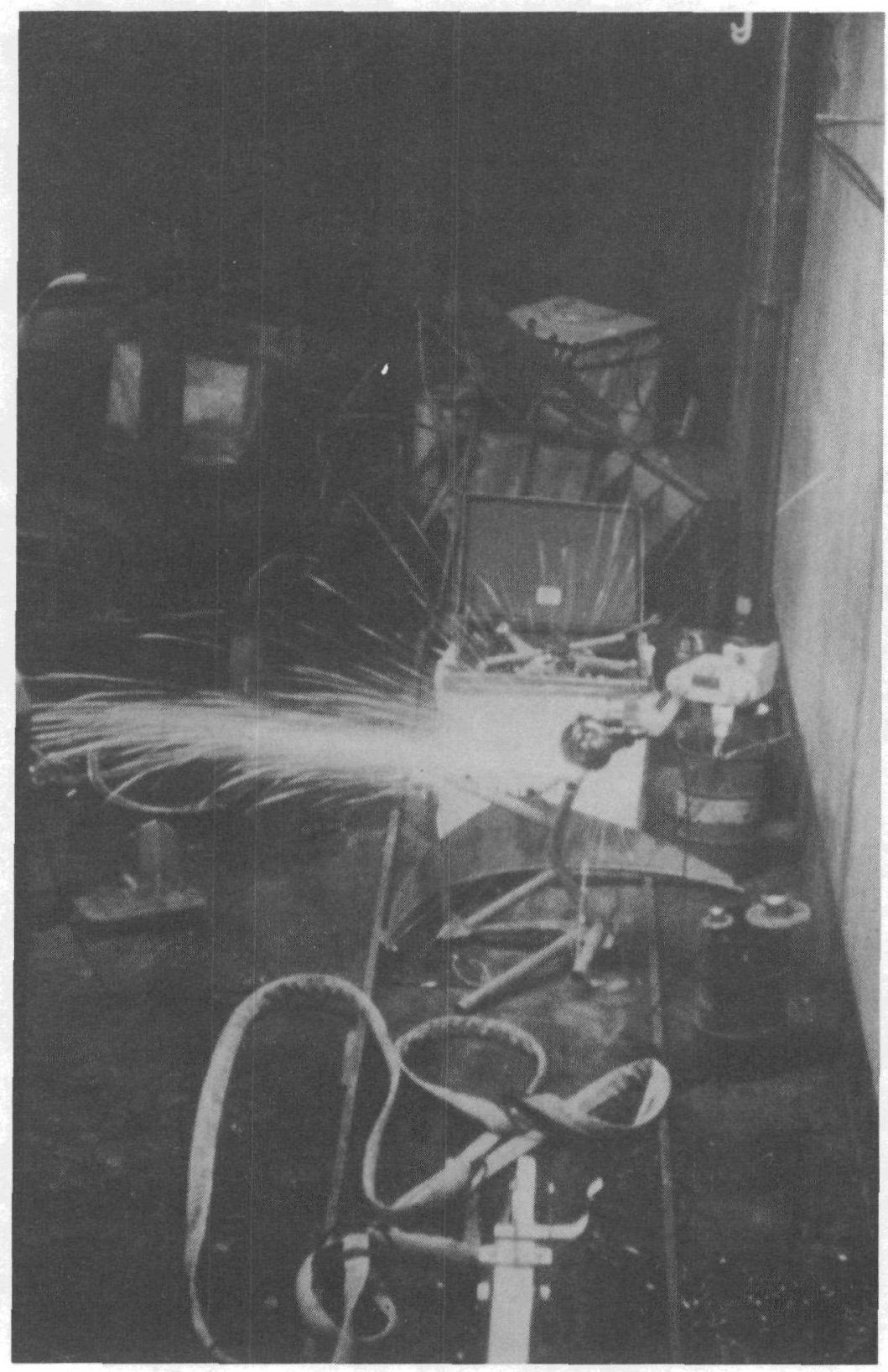

FIGURE 31

Commercially Avallable Abrasive Saw

Adapted for Use by CPC Manipulator 


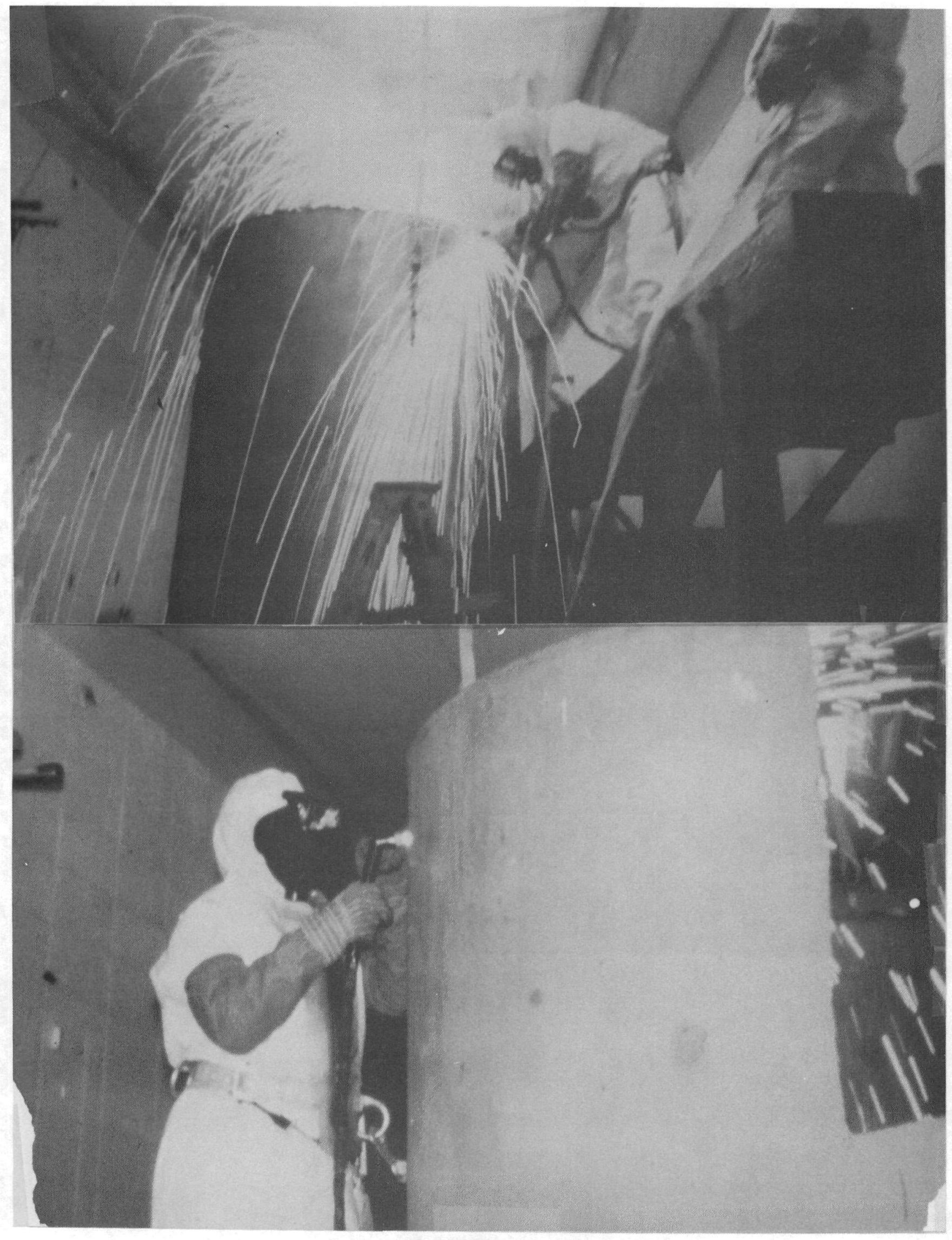

FIQURE 32

Plasma Arc Cutting In Contact Size Reduction of Contaminated Vessels 


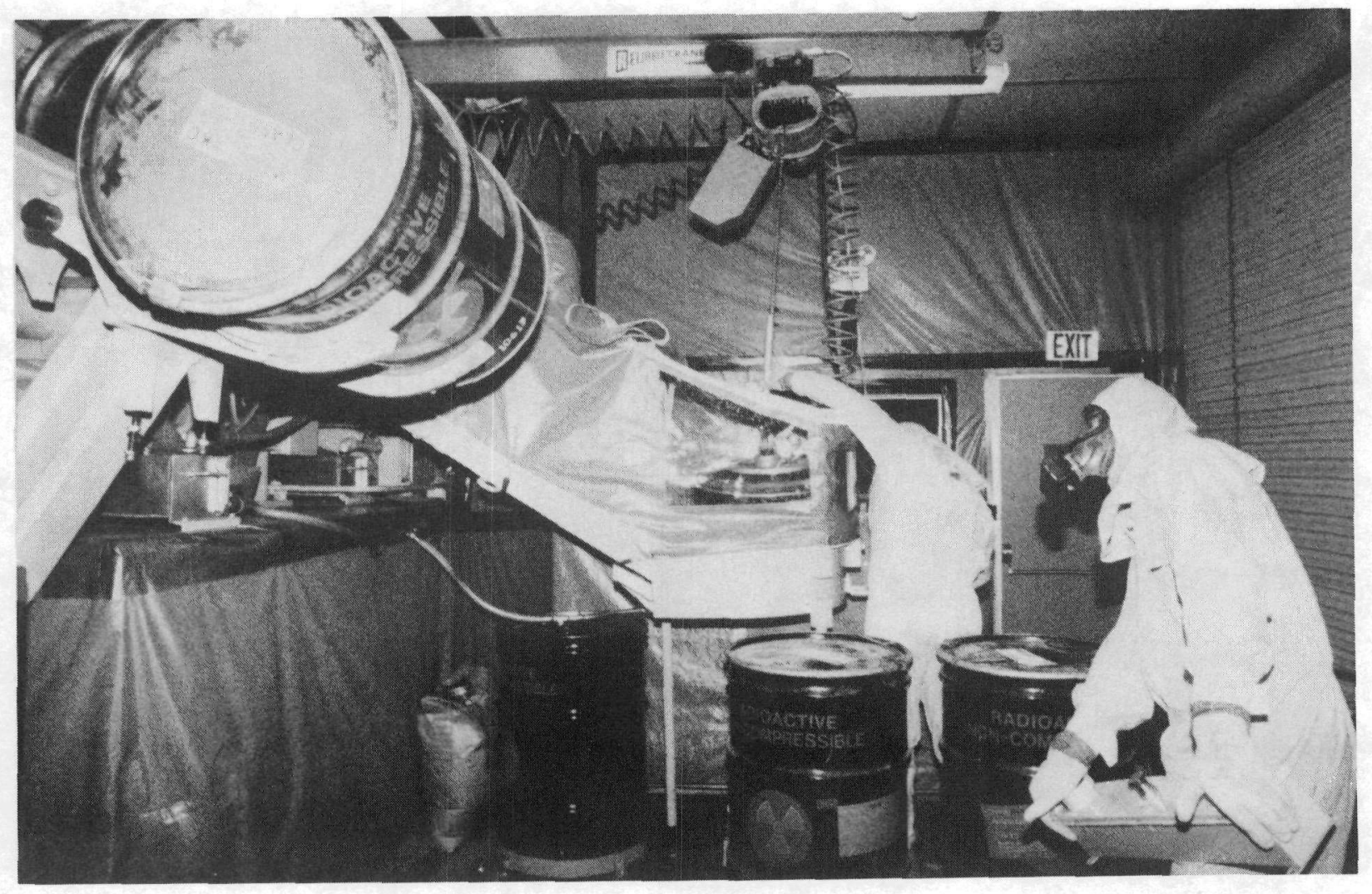

FIGURE 33

supercompactor in Operation 


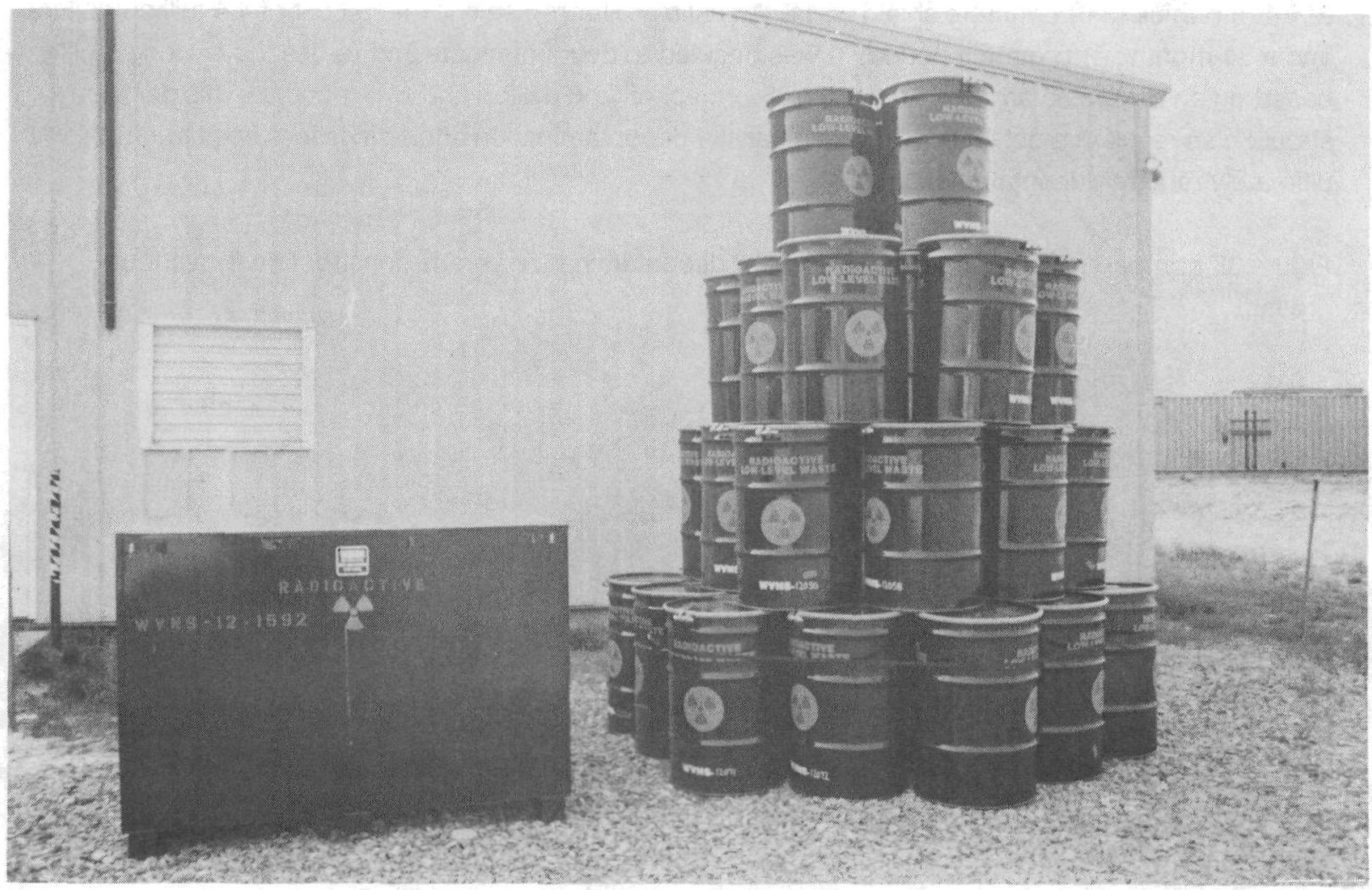

FIQURE 34

Example of Supercompactor Volume Reduction (44 Drums=One 2.5 $\mathrm{M}^{3}$ Box) 


\subsection{COST BENEFIT ANALYSIS}

Early in the Project, two alternatives were considered in which to install the processing equipment for treating the HLW. The possibilities were to decontaminate and reuse existing cells in the former reprocessing plant or to construct new facilities.

A cost comparison for the LWTS was made for new construction versus cleanup and re-use. The comparison included a $\$ 7$ million cost estimate and 36-month design and construction schedule based on constructing a new, seismically qualified LWTS facility with a 42,500- $\mathrm{m}^{3}\left(1,500,000 \mathrm{ft}^{3}\right)$ volume and 914.4-mm-thick ( $3 \mathrm{ft}$ ) concrete shield walls. An estimate for re-use showed a cost of 4.4 million dollars and a 34-month performance period. It was decided to decontaminate and re-use the existing facility based on an estimated savings for the LWTS project of $\$ 2.6$ million and two months. This decision should also result in a net savings for the final site decontamination effort since less site structures will ultimately require decontamination.

Figure 35 compares the cost per cubic foot for decontamination versus construction for various areas $^{[25]}$. 


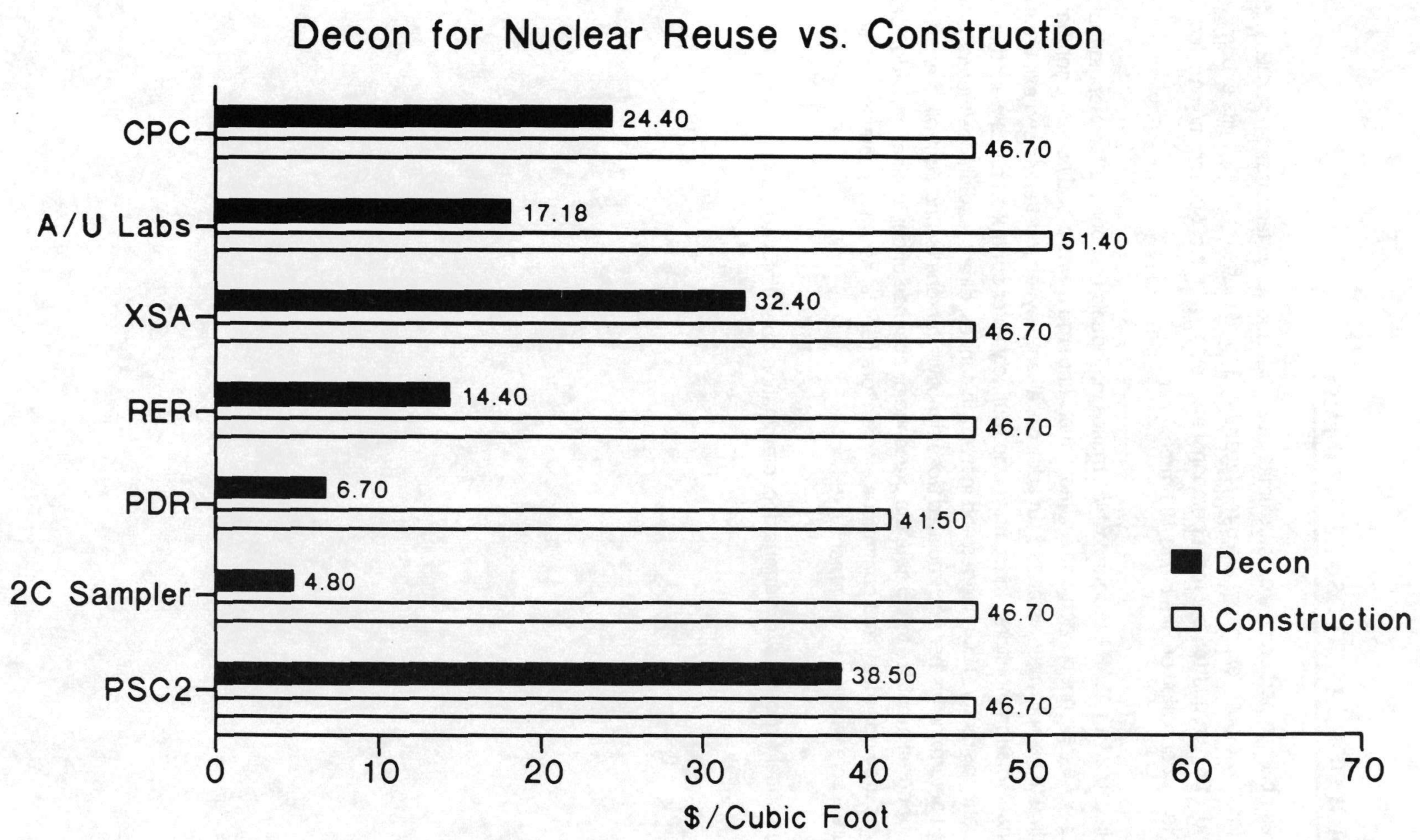

FIGURE 35

Analysis for Decontamination and Reuse vs. New Construction 


\subsection{RADIOLOGICAL EXPOSURE SUMMARY}

WVNS has established personnel exposure limits well below industry standards and DOE limits. The DOE limits for whole-body exposure are $5 \mathrm{rem} / \mathrm{year}$ and $3 \mathrm{rem} /$ quarter. WVNS limits exposures to 3 $\mathrm{rem} /$ year and $1.25 \mathrm{rem} /$ quarter, but most personnel are held to a limit of $500 \mathrm{mrem} /$ year. Individuals not in a nuclear occupation are limited to $100 \mathrm{mrem} /$ year.

WVNS has instituted an ALARA program which makes individuals responsible for keeping their exposure As Low As Reasonably Achievable. Individuals undergo a whole-body count upon being hired and at the time the employment is ended. In addition, all employees must enter and exit the site through portal radiation monitors. Individuals who routinely enter controlled areas wear thermoluminescent dosimetry (TLD) badges and in many instances, direct reading dosimeters which allow the wearer to determine his/her accumulated dose directly. Persons exiting controlled areas must also use friskers or portal monitors to indicate the presence or absence of contamination. Additional instruments such as area dosimetry and continuous air monitors (CAMs) as well as routine radiation surveys help to insure a safe working environment.

The total personnel exposures for various decontamination operations are listed in table 5 . 
TABLE 5: Iotal Personnel Exposures for Various DecontaminatION OPERATIONS

Location

XCR

XC3

PPC

UPC

ULO

UWA

LWA

XSA

CPC

EDR

CCR

SRR

Analytical Cells

MSMRS

8D-1 (Riser

installation)

8D-2 (Riser

installation)
Exposure (Man-

Rem)

3.5

3.4

2.8

0.1

0.7

0.7

0.4

0.5

11.4

7.7

2.2

1.0

1.8

2.9

1.0

2.4 


\subsection{ACKNOWLEDGMENTS}

The authors were very fortunate in being able to interview many members of the West Valley Decontamination Team. Their contributions to the work reported are indeed significant.
W. A. Bridenbaker
J.W. Burrell
T. M. Conlin
B. J. Connors
A. C. Feuz
W. P. Freaney
D. H. Garland
D. S. Kaczmarski
R. B. Keel
E. Maestas
S. Marchetti
C. W. McVay
R. A. Meigs
G. H. Metzler
D. Pezzimenti
J. A. Sage
D. J. Sawyer
T. L. Sonntag
R. G. Spaunburgh
D. R. Steffes
J. E. Tangelder
P. J. Valenti
R. E. Vandervort
P. M. Vlad
L. Wiedemann
D. L. Wiltse

Significant help in the preparation of this report was afforded by Ms. K. A. Garrett, Ms. B. J. Miller, D. A. Lipka and Ms. L. A. Howard. Photos were taken by R. A. Grant, D. T. Kasper and by members of the decontamination team. 


\subsection{REFERENCES}

1. Riethmiller, G. E.; History of Decontamination, Nuclear Fuel Services Inc., 1981.

2. Woods, P. G.; "The West Valley Demonstration Project...A Nuclear Success Story," West Valley, NY: WVNS, Inc., 1986.

3. Skillern, C. G.; "West Valley Demonstration Project Facilities Utilization Plan for the Existing Facilities at the Western New York Nuclear Service Center," May 1986: DOE/NE/44139-12, (DE87005886).

4. U.S. Department of Energy; "Environmental Impact Statement: Long-Term Management of Liquid High-Level Radioactive Wastes Stored at the Western New York Nuclear Service Center, West Valley New York," National Technical Information Service, Springfield, VA 22161, June 1982.

5. Daugherty, H. F., Keel, R.; "Decontamination of the West Valley Reprocessing Plant," November 1986: DOE/NE/44139-30.

6. Smokowski, R. T.; "Analytical Cell Decontamination and Shielding Window Refurbishment," December 1985: DOE/NE/44139-1 (DE86010127).

7. Phillips, E. C.; "Decontamination and Decommissioning of the Extraction Chemical Room at the West Valley Demonstration Project," December 1985: DOE/NE/44139-7.

8. Allen, J. C.; "Decontamination of the Warm Aisles at the West Valley Demonstration Project," June 1986: DOE/NE/44139-11 (DE86015760).

9. Allen, J. C.; "Decontamination of the Extraction Sample Aisle at the West Valley Demonstration Project," September 1986: DOE/NE/44139-28 (DE87006872).

10. Phillips, E. C., Golden, M. P.; "Decontamination and Renovation of the Master/Slave Manipulator Repair Shop and the Chemical Crane Room at the West Valley Demonstration Project," January 1986: DOE/NE/44139-4, (DE86010531).

11. Frank, D. E., Reeves, S. R., Valenti, P. J.; "Design, Construction and Operation of the Contact Size Reduction Facility at the West Valley Demonstration Project," May 1988: DOE/NE/44139-46.

12. Jones, E. D.; "Decontamination and Decommissioning of Extraction Cell 3 at the West Valley Demonstration Project," December 1985: DOE/NE/44139-3, (DE86010129). 
13. Burke, D. F.; "Decontamination of the Product Purification Cell at the West Valley Demonstration Project," July 1986: DOE/NE/44139-10 (DE87000663).

14. Phillips, E. C.; "Decontamination of the Product Handling Area at the West Valley Demonstration Project," June 1986: DOE/NE/44139-9 (DE87005772).

15. Meigs, R. A.; "Decontamination and Decommissioning of the Chemical Process Cell (CPC)," July 1987: DOE/NE/44139-41 (DE88002431).

16. Meigs, R. A.; "Initial Decontamination of the Equipment Decontamination Room at the West Valley Demonstration Project," December 1985: DOE/NE/44139-2 (DE86010128).

17. Phillips, E. C., Golden, M. P.; "Decontamination and Renovation of the Master/Slave Manipulator Repair Shop and the Chemical Crane Room at the West Valley Demonstration Project," January 1986: DOE/NE/44139-4, (DE86010531).

18. Jackson, J. P., Gessner, R. F.; "Remote Installation of Risers on Underground Nuclear Waste Storage Tanks," May 1988: DOE/NE/44139-45.

19. Same as Reference 5.

20. "Radiation Worker Training Manual," West Valley Nuclear Services, Co. Inc., 1983.

21. "D\&D Operator Training and Qualification Manual," West Valley Nuclear Services, Co. Inc., 1986.

22. "West Valley Demonstration Project Safety Analysis Report - Volume II," West Valley, NY: West Valley Nuclear Services, Co. Inc., 1985.

23. Wiedemann, L. W., Standish, P. N.; "Use of a Cutting and Cleaning System at the West Valley Demonstration Project," April 1986: DOE/NE/44139-8,.

24. Same as Reference 11.

25. Daugherty, H. F., Sage, J. A.; "Cost Benefit Analysis for Reuse of Nuclear Facilities," West Valley, NY: West Valley Nuclear Services, Co. Inc., 1986. 


\subsection{BIBLIOGRAPHY}

1. Riethmiller, G. E.; History of Decontamination, Nuclear Fuel Services Inc., 1981.

2. Woods, P. G.; "The West Valley Demonstration Project...A Nuclear Success Story," West Valley Nuclear Services, Co. Inc., 1986.

3. Skillern, C. G.; "West Valley Demonstration Project Facilities Utilization Plan for the Existing Facilities at the Western New York Nuclear Service Center," DOE/NE/44139-12, May 1986.

4. U.S. Department of Energy, "Environmental Impact Statement: Long-Term Management of Liquid High-Level Radioactive Wastes Stored at the Western New York Nuclear Service Center, West Valley New York"; National Technical Information Service, June 1982.

5. Daugherty, H. F., Keel, R.; "Decontamination of the West Valley Reprocessing Plant," DOE/NE/44139-30, November 1986.

6. Smokowski, R. T.; "Analytical Cell Decontamination and Shielding Window Refurbishment," DOE/NE/44139-1, December 1985.

7. Phillips, E. C.; "Decontamination and Decommissioning of the Extraction Chemical Room at the West Valley Demonstration Project," DOE/NE/44139-7, December 1985.

8. Allen, J. C.; "Decontamination of the Warm Aisles at the West Valley Demonstration Project," DOE/NE/44139-11, June 1986.

9. Allen, J. C.; "Decontamination of the Extraction Sample Aisle at the West Valley Demonstration Project," DOE/NE/44139-28, September 1986.

10. Phillips, E. C., Golden, M. P.; "Decontamination and Renovation of the Master/Slave Manipulator Repair Shop and the Chemical Crane Room at the West Valley Demonstration Project," DOE/NE/44139-4, January 1986.

11. Frank, D. E., Reeves, S. R., Valenti, P. J.; "Design, Construction and Operation of the Contact Size Reduction Facility at the West Valley Demonstration Project," DOE/NE/44139-46, May 1988.

12. Jones, E. D.; "Decontamination and Decommissioning of Extraction Cell 3 at the West Valley Demonstration Project," DOE/NE/44139-3, December 1985.

13. Burke, D. F.; "Decontamination of the Product Purification Cell at the West Valley Demonstration Project," DOE/NE/44139-10, July 1986. 
14. Phillips, E. C.; "Decontamination of the Product Handling Area at the West Valley Demonstration Project," DOE/NE/44139-9, June 1986.

15. Meigs, R. A.; "Decontamination and Decommissioning of the Chemical Process Cell (CPC)," DOE/NE/44139-41, July 1987.

16. Meigs, R. A.; "Initial Decontamination of the Equipment Decontamination Room at the West Valley Demonstration Project," DOE/NE/44139-2, December 1985.

17. Jackson, J. P., Gessner, R. F.; "Remote Installation of Risers on Underground Nuclear Waste Storage Tanks," DOE/NE/44139-45, May 1988.

18. "Radiation Worker Training Manual," West Valley Nuclear Services, Co. Inc., 1983.

19. "D\&D Operator Training and Qualification Manual," West Valley Nuclear Services, Co. Inc., 1986.

20. "West Valley Demonstration Project Safety Analysis Report - Volume II," West Valley Nuclear Services, Co. Inc., 1985.

21. Wiedemann, L. W., Standish, P. N.; "Use of a Cutting and Cleaning System at the West Valley Demonstration Project," DOE/NE/44139-8, April 1986.

22. Daugherty, H. F., Sage, J. A.; "Cost Benefit Analysis for Reuse of Nuclear Facilities," West Valley Nuclear Services, Co. Inc., 1986.

23. Vance, R. F.; "Characterization of the Head End Cells at the West Valley Nuclear Fuel Reprocessing Plant," DOE/NE/44139-31, October 1986.

24. Bridenbaker, W.; "Decontamination of the Scrap Removal Room at the West Valley Demonstration Project," DOE/NE/44139-33, March 1987.

25. Knabenschuh, J. L.; "Present Status of the West Valley Demonstration Project," ANS Topical Meeting, April 1982.

26. Rykken, L. E., Bray, L.; "In-Cell Vitrification Testing of High-Level Liquid Waste Decontamination Process," AICHE Meeting, March 1984.

27. Picazo, E. D., Marchetti, S., Wilcox, D. P.; "Environmental Conference Characterization of the West Valley Site," Waste Management '84, March 1984. 
28. Cwynar, J. C., Eisenstatt, L. R., Goodman, J., Petrone, P. M.; "Low-Level and TRU Waste Management at West Valley," Waste Management '84 Conference, March 1984.

29. Daugherty, H. F., Golden, M. P., Jacoby, W. R., Krauss, J. E.; "Decontamination and Decommissioning at the West Valley Site - Progress and Plans," Waste Management '84 Conference, March 1984.

30. Knabenschuh, J. L., Englert, A. E., Hannum, W. H.; "The West Valley Demonstration Project Three Years of Progress," Waste Management '85 Conference, March 1985.

31. Richmond, W. G., Pope, J. M.; "Retrofitting of Existing Facilities Versus Construction of New Facilities for the Vitrification of High-Level Nuclear Waste at West Valley (Abstract/Summary)," ANS Topical Meeting, September 1985.

32. Rykken, L. E., Carl, D. E., Bray, L. A., Goldman, D. S.; "Design Considerations for Removal, Temporary Storage and Packaging of Radioactive Components from a High-Level Waste Liquid at West Valley (Abstract/Summary)," ANS Topical Meeting, September 1985.

33. Maestas, E., Goodman, J., Cwynar, J. C.; "Low-Level Waste Management at the West Valley Demonstration Project," Low-Level Waste Participation Meeting, September 1985.

34.Schiffhauer, M. A.; "Abstract - High-Level Radioactive Waste Removal from Underground Storage Tanks for the Purpose of Waste Solidification and Tank Decontamination."

35. Cwynar, J. C., Nasol, A. L., Petrone, P. M.; "Abstract - Retrofit of Radwaste Solidification System into an Existing Facility."

36. Knabenschuh, J. L., Lawrence, R. E.; "Abstract - Decontamination and Dismantling of the West Valley, New York Processing Plant - Techniques Applied, Results Obtained and Lessons Learned."

37. Rykken, L. E.; "Analytical Characterization of West Valley High-Level Waste Sludge," October 1985.

38. Phillips, E. C., Golden, M. P.; "Decontamination of the CCR and Decontamination and Decommissioning of the Extraction Chemical Room at the WVDP," 19th Midyear Symposium of the Health Physics Society, February 1986.

39. Jones, E.D., Vandervort, R. E.; "Remote Hydraulic Manipulator Arm," 19th Midyear Symposium of the Health Physics Society, February 1986.

40. Jones, E. D., Burke, D. F.; "Decontamination and Decommissioning of Extraction Cell 3 at the WVDP," 19th Midyear Symposium of the Health Physics Society, February 1986. 
41. Keel, R.; "Contamination Control and Respiratory Protection for Extraction Cell Entries Involving High Concentrations of Airborne Activity (Abstract Only)," 19th Midyear Symposium of the Health Physics Society, February 1986.

42. Petrone, P. M., Cwynar, J. C., Dietrich, A. J.; "Retrofit and Operation of Low-Level Radwaste Solidification System," Waste Management '86 Conference, March 1986.

43. Daugherty, H. F., Keel, R.; "Decontamination and Decommissioning of the West Valley Reprocessing Plant (Abstract)," ANS-Summer Meeting, June 1986.

44. Valenti, P. J., McVay, C. W., Bourgeois, P. M.; "WVNS Experience in the Detection, Monitoring and Remediation of Leaking Underground Tanks Containing Radioactive Kerosene," ANS-Summer Meeting, June 1986.

45. Woods, P. G., DiFrancesco, D. L.; "The WVDP - A Nuclear Success Story," Society of Women Engineers Meeting, June 1986.

46. Peterson, J. M., Englert, J. P.; "Estimation of Residual Radioactivity within a Shutdown Fuel Reprocessing Plant," Spectrum '86 Conference, September 1986.

47. Daugherty, H. F., Keel, R; "Decontamination and Decommissioning of the West Valley Reprocessing Plant," Spectrum '86 Conference, September 1986.

48. Braunscheidel, M. J.; "The Design and Installation of the West Valley Supernatant Treatment System," Spectrum ' 86 Conference, Niagara Falls, NY, September 1986.

49. Hoffman, W. D.; "The Public Visits a Nuclear Waste Site: Survey Results from the West Valley Demonstration Project," Waste Management '87 Conference, Tucson, AZ, March 1987.

50. Vandervort, R. E., Meigs, R. A.; "Application of Remote Systems/Robotics for Decontamination at West Valley (Summary)," Remote Systems/Robotics Conference, April 1987.

51. Knabenschuh, J. L., Daugherty, H. F., Hannum, W. H.; "The Application of Remote Systems and Robotics to the Decontamination of High-Level Radiation and Contamination Cells at West Valley (Abstract)," ANS-Topical Meeting on Remote Systems and Robotics in Hostile Environments, April 1987.

52. Standish, P. N., Swenson, C. E., Petrone, P. M.; "Remote Handling of High Dose Rate Low-Level Waste Drums," ANS-Topical Meeting on Remote Systems and Robotics in Hostile Environments, April 1987. 
53. Stout, B. J., Gessner, R. F.; "Processing Nuclear Waste at West Valley -Women's Role on the Team (Paper)," The Society of Women Engineers National Convention, June 1987.

54. Jackson, J. P.; "Nuclear Waste Clean-Up Using Remote Technology, (Abstract/Paper)," The Society of Women Engineers National Convention, June 1987.

55. Meigs, R. A.; "Use of Foam Chemicals for Decontamination," DOE-Sponsored International Decommissioning Symposium, Pittsburgh, PA, October 1987.

56. Vandervort, R. E., Wiedemann, L. W.; "Remote Cutting and Removal of Chemical Processing Cell's Concrete Pedestal Bases," DOE-Sponsored International Decommissioning Symposium, Pittsburgh, PA, October 1987.

57. Meigs, R. A., Lawrence, R. E.; "D\&D of the Chemical Process Cell (CPC) at the West Valley Reprocessing Facility," DOE-Sponsored International Decommissioning Symposium, Pittsburgh, PA, October 1987.

58. Meigs, R. A., Palau, G. L.; "Decontamination Operations in the Chemical Process Cell at the West Valley Demonstration Project," American Nuclear Society Winter Meeting, November 1987.

59. Brown, S. H., Gordon, J. W.; "Development of Site-Specific Radiological Decommissioning Criteria for a High-Level Waste Processing and Vitrification Project (Paper)," Waste Management '88 Conference, February 28 to March 3, 1988.

60. Valenti, P. J., Vandervort, R. E.; "Operational Benefits from D\&D Work at West Valley Demonstration Project (Summary)," American Nuclear Society Power Division Topical Meeting, April 1988.

61. Frank, D. E., Reeves, S. R., Valenti, P. J.; "An Integrated Approach to Volume Reduction at the West Valley Demonstration Project (Abstract/Paper)," Spectrum '88 Conference, September 1988.

62. Steffes, D. R.; "Status of Industry Standards for Decommissioning of Nuclear Facilities (Abstract/Paper)," Spectrum '88 Conference, September 1988. 